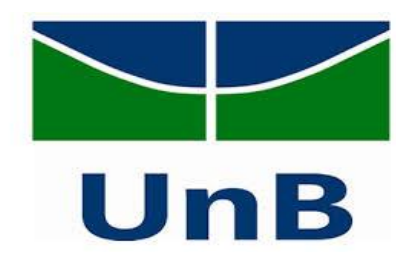

UNIVERSIDADE DE BRASÍLIA

PROGRAMA DE PÓS-GRADUAÇÃO EM QUÍMICA

\title{
DESENVOLVIMENTO DE PROTOCOLOS ANALÍTICOS EM METABOLÔMICA DE LEVEDURAS FERMENTADORAS DE XILOSE
}

CHRISTIANE GONÇALVES CAMPOS

Orientadora: Dra. Patrícia Verardi Abdelnur

BRASÍLIA - DF

2015 


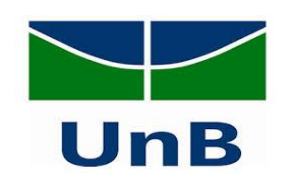

\author{
UNIVERSIDADE DE BRASÍLIA \\ INSTITUTO DE QUÍMICA
}

\title{
DESENVOLVIMENTO DE PROTOCOLOS ANALÍTICOS EM METABOLÔMICA DE LEVEDURAS FERMENTADORAS DE XILOSE
}

CHRISTIANE GONÇALVES CAMPOS

Dissertação apresentada ao Instituto de Química da Universidade de Brasília como parte do requisito para obtenção do título de Mestre em Química.

Orientadora: Dra. Patrícia Verardi Abdelnur

\author{
Brasília - DF
}


- Universidade de Brasilia

Instituto de Quimica (IQ)

\title{
COMUNICADO
}

Comunicamos a aprovaçฐ̃ đa Defesa de Dissertaçăo de Mestrado do (a) aluno (a) Christiane Gonsalves Campos, matricula na 13/0086240, intitulada "Desenvalvimento de protocolos onaliticos em metabalámica de leveduras fermentadoras de xilose", apresentada no (a) Auditório Verde do Instituto de Quimica (IQ) da Universidade de Brasilia (UnB) em 5 de março de 2015.

Ora. Patricia Verardi Abdelnur Presidente de Banca (Embrapa Agroenereja)

\author{
Prof. Dr. Brenno Amaro da Silveira Neto \\ Membro Titular [Q:/UnB] \\ Dr. Clenilson Martins Rodfieves \\ Membro Titular (Embrapa Agroenergia) \\ Dr, Joz̄e Ricardo Moreira de Almeida \\ Membeo Suplente (Embrapa Agroenergia)
}

Em 5 de marpo de 2015.

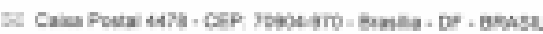

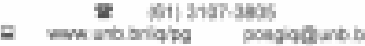


Em homenagem aos meus pais Julio Cesar e Wilma. 


\section{Agradecimentos}

Agradeço a família que eu tive a benção de constituir: minha filha Júlia, tão carinhosa, meu esposo Thiago presente nos momentos mais difíceis.

Aos meus pais Julio e Wilma que me deram um excelente exemplo de caráter e dignidade, sempre me apoiaram e se não fosse por eles eu não teria chegado até aqui.

A minha orientadora Dra. Patrícia Verardi Abdelnur, por acreditar em mim, guiar-me pelo caminho da ciência e por ser um exemplo como profissional.

Aos amigos que estiveram presente nesta fase da minha vida me ajudando e incentivando.

A todos da Embrapa Agroenergia pelo carinho e apoio, em especial ao analista José Antônio por sua ajuda valiosa, e aos pesquisadores e doutores Clenilson Martins Rodrigues e João Almeida pela ajuda e orientação e por aceitarem o convite para serem membros da banca examinadora.

A todos do Instituto de Química em especial ao professor Dr. Brenno Amaro da Silveira Neto pela orientação, e por aceitar o convite para ser membro da banca examinadora. 


\section{Resumo}

O aumento na demanda por fontes de energia alternativa e as preocupações com os impactos ambientais tem incentivado o desenvolvimento de tecnologias para a produção de combustíveis a partir de biomassa lignocelulósica, como o etanol de segunda geração (2G). No entanto um dos açúcares mais abundante nas biomassas lignocelulósicas, a xilose, não pode ser convertida a etanol devido à incapacidade da levedura Saccharomyces cerevisiae, microrganismo mundialmente utilizado na indústria para produção de etanol, de converter eficientemente esse substrato em xilulose. A tecnologia baseada em metabolômica mostra-se eficiente, como uma ferramenta para auxiliar na determinação das etapas limitantes na via metabólica de fermentação da xilose. Neste trabalho, foram desenvolvidos e otimizados dois protocolos para análise de metabolômica targeted, utilizando como plataforma analítica a cromatografia líquida acoplada à espectrometria de massas tandem (LC-MS/MS) com experimentos de MRM. Os métodos de separação foram baseados na cromatografia por pareamento iônico utilizando uma coluna de fase reversa (HSS-T3) e na cromatografia de interação hidrofílica (HILIC), utilizando uma coluna quimicamente modificada com o grupo amida. Catorze padrões de metabólitos presentes na via de fermentação da xilose puderam ser identificados através de dois métodos complementares. Estes protocolos foram aplicados qualitativamente durante a avaliação de duas leveduras, Scheffersomyces stipitis e Spathaspora passalidarum. O preparo de amostra foi realizado em duas etapas: quenching e extração dos metabólitos. Os métodos de separação e deteç̧ão se mostraram promissores para a análise de rotina em processos de fermentação de xilose. 


\begin{abstract}
The increase in demand for alternative energy sources and concerns about the environmental impacts has encouraged the development of technologies for the production of fuels from lignocellulosic biomass, such as ethanol from second generation (2G). However one of the most abundant sugars in lignocellulosic biomass, xylose, can not be converted into ethanol due to the inability of yeast Saccharomyces cerevisiae, which is a microorganism used worldwide in the industry for the production of ethanol, to convert this substrate into xylulose efficiently. The technology based on metabolomics proves to be efficient as a tool to identify the crucial steps in the metabolic pathway of xylose fermentation. In this work, we developed and optimized two protocols for targeted metabolomics analysis, using as an analytical platform liquid chromatography coupled to tandem mass spectrometry (LC-MS/MS) with MRM experiments. Separation methods were based on the ion pairing chromatography using a reverse phase column (HSS-T3) and hydrophilic interaction chromatography (HILIC) with a chemically modified column with amide group. Fourteen patterns of metabolites present in the xylose fermentation pathway could be identified using two complementary methods. These protocols were applied qualitatively during the evaluation of two yeast, Scheffersomyces stipitis and Spathaspora passalidarum. The sample preparation was performed in two stages: quenching and extraction of metabolites. The methods of separation and detection were promising for routine analysis in the xylose fermentation processes.
\end{abstract}




\section{Sumário}

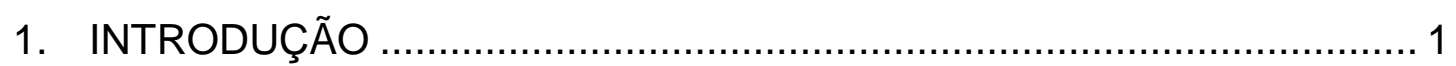

1.1. Etanol de Segunda Geração (2G) ................................................ 1

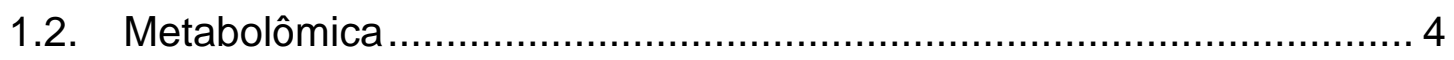

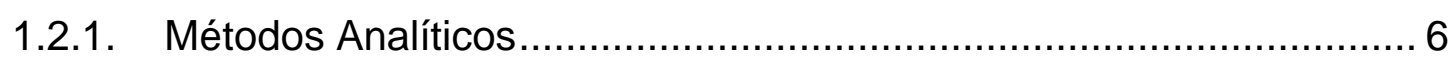

1.2.1.1. Espectrometria de massas (MS - Mass Spectrometry)................. 6

1.2.1.2. Espectrometria de massas Tandem ........................................... 9

1.2.1.3. Métodos cromatográficos acoplados a espectrometria de massas 11

1.2.1.4. Cromatografia Líquida de Ultra Alta Eficiência acoplada à espectrometria de massas (UHPLC-MS) .............................................. 13

1.2.2. Preparo de amostra em metabolômica..................................... 15

1.2.3. Metabolismo de xilose em leveduras ............................................. 18

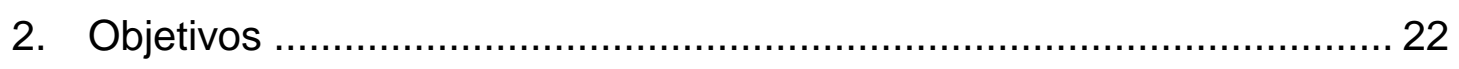

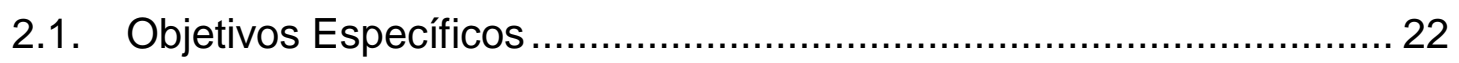

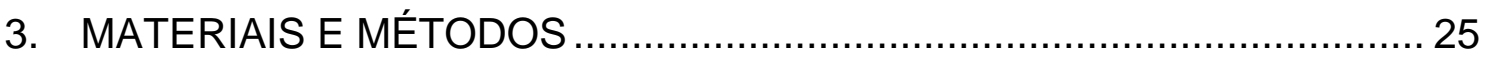

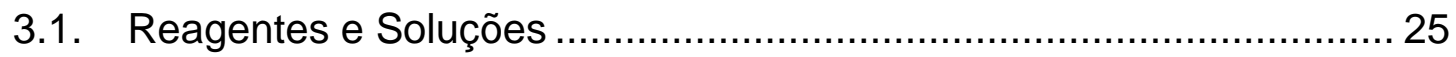

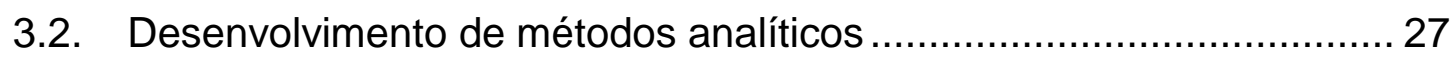

3.2.1. Espectrometria de Massas (MS- Mass Spectrometry) .................... 27

3.2.2. Cromatografia líquida de ultra alta eficiência acoplada a espectrometria de massas (UHPLC-MS) ............................................. 31

3.2.2.1. Cromatografia de interação hidrofílica (HILIC-Hydrophilic

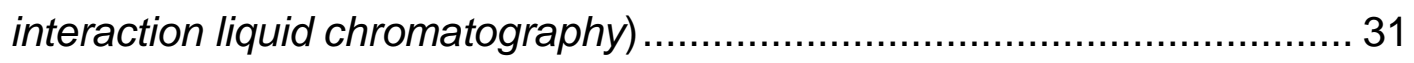
3.2.2.2. Cromatografia por pareamento iônico (IPC - lon-pair

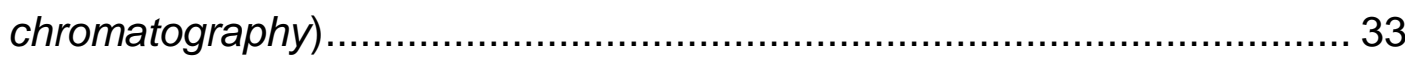

3.2.2.3. Cromatografia por troca iônica (IEC - lon Exchange

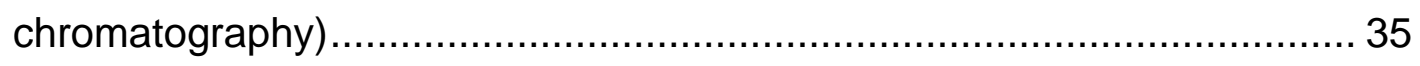

3.3. Preparo das amostras de leveduras ........................................ 35

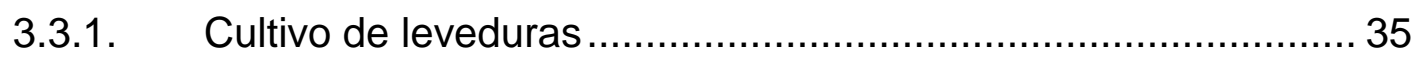

3.3.2. Etapas de quenching e extração dos metabólitos ..................... 36

3.3.3. Reconstituição dos metabólitos para análise por UHPLC-MS... 38 


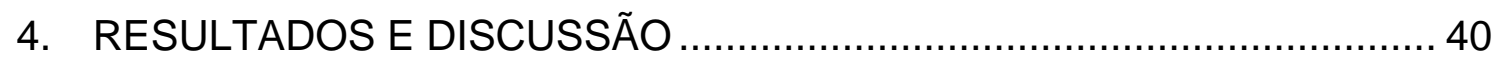

4.1. Desenvolvimento de método por Espectrometria de Massas ............. 40

4.1.1. Espectrometria de massas tandem (MS/MS) e Multiple Reaction

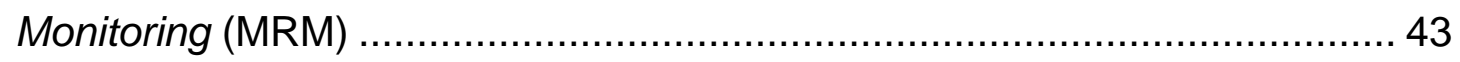

4.2. Desenvolvimento do método por UHPLC-MS ….............................. 55

4.2.1. Cromatografia de interação Hidrofílica (HILIC - Hydrophilic Interaction

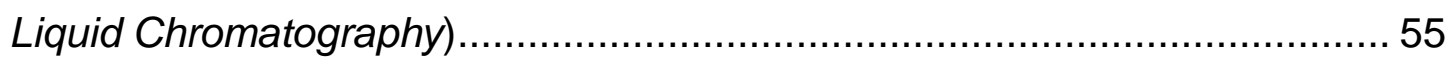

4.2.2. Cromatografia por Pareamento lônico (IPC- ion pair chromatography) 61

4.2.3. Cromatografia por troca iônica (IEC - Ion Exchange chromatography) 69

4.3. Análises das Amostras Biológicas por UHPLC-MS/MS .................... 73

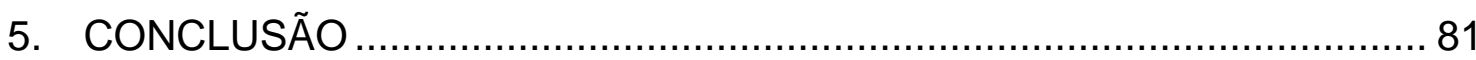

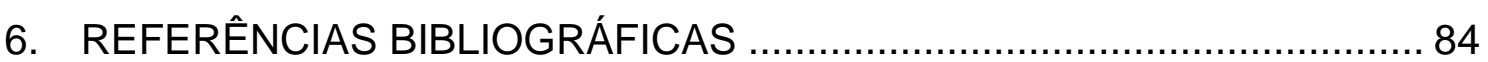




\section{Lista de Abreviaturas e Acrônimos}

Acald - Acetaldeído

ACCOA - Acetil Co-enzima A

ACN - Acetonitrila

AKG - Ácido Alfacetoglutárico

CE - Cromatografia Eletroforese (do inglês, Capillary Electrophoresis)

CE-MS - Cromatografia eletroforese capilar acoplada a Espectrometria de

Massas (do inglês, Capillary Electrophoresis Chromatography - Mass

Spectrometry)

CG - Cromatografia Gasosa (do inglês, Gas Chromatography)

DHAP- Dihidroxi Acetona Fosfato

DIMS - Infusão direta por Espectrometria de Massas (do inglês, Direct Infusion

Mass Spectrometry)

ESI - lonização por Electrospray (do inglês, Electrospray ionization)

ESI-MS - Ionização por Electrospray e detecção por Espectrometria de massas

(do inglês, Electrospray ionization-Mass Spectrometry)

F6P- Frutose-6-fosfato

FE - Fase Estacionária

Femtomol $-10^{-15} \mathrm{~mol}$

FM - Fase Móvel

G6P - Glicose-6-fosfato

GAP - Gliceraldeído-3-fosfato

GC-MS - Cromatografia Gasosa acoplada a Espectrometria de Massas (do inglês, Gas Chromatography - Mass Spectrometry)

HILIC - Cromatografia por Interação Hidrofílica (do inglês, Hydrophilic

Interaction Liquid Chromatography)

IEC - Cromatografia por Troca lônica (do inglês, lon Exchange

Chromatography)

IPC - Cromatografia por Pareamento lônico (do inglês, lon Pair

Chromatography) 
LC - Cromatografia Líquida (do inglês, Liquid Chromatography)

LC-MS - Cromatografia Líquida acoplada a Espectrometria de Massas (do inglês, Liquid Chromatography - Mass Spectrometry)

L-MAL- Ácido Málico

MRM - Monitoramento de Reações Múltiplas (do inglês, Multiple Reaction

Monitoring)

MS - Espectrometria de Massas (do inglês, Mass Spectrometry)

Oaa - Ácido Oxaloacético

PEP - Fosfo(enol)piruvato

Picomol $-10^{-12} \mathrm{~mol}$

PYR - Piruvato de sódio

R5P - Ribose-5-fosfato

RU5P - Ribulose-5-fosfato

TBA - Tributilamina

TEA - Trietilamina

TIC - Cromatograma de íons totais (do inglês, Total lon Chromatogram)

UHPLC - Cromatografia Líquida de Ultra Alta Eficiência (do inglês, Ultrahigh Performance Liquid Chromatography)

UHPLC-MS - Cromatografia Líquida de Ultra Alta Eficiência acoplada a espectrometria de massas (do inglês, Ultrahigh Performance Liquid Chromatography-Mass Spectrometry) 


\section{Lista de Tabelas}

Tabela 1. Comparação dos procedimentos de extração dos metabólitos intracelulares em microrganismos classificados em ótimo $=x x x$, bom $=x x$ e pouco eficiente $=x$.

Tabela 2. Dados do preparo das soluções estoque dos padrões de metabólitos analisados.

Tabela 3. Valor teórico das massas dos padrões de metabólitos de interesse.

Tabela 4. Concentração dos padrões de metabólitos diluídos para o preparo da mistura de $10 \mu \mathrm{g} \cdot \mathrm{mL}^{-1}$.

Tabela 5. Concentração dos padrões de metabólitos diluídos individualmente.

Tabela 6. Condições cromatográficas testadas para o desenvolvimento do método HILIC utilizando a coluna BEH amida.............................................. 32

Tabela 7. Gradiente aplicado no método HILIC otimizado............................. 33

Tabela 8. Condições cromatográficas testadas para o desenvolvimento do método IPC utilizando a coluna HSS-T3......................................................... 34

Tabela 9. Gradiente aplicado no desenvolvimento do método IPC. ................ 34

Tabela 10. Condições cromatográficas testadas para o desenvolvimento do método IEC utilizando a coluna Aminex.......................................................... 35

Tabela 12. Condições experimentais otimizadas para experimentos de MRM dos padrões de metabólitos utilizando ESI(-)-MS/MS. 46 


\section{Lista de Figuras}

Figura 1. Esquema da produção de etanol combustível a partir do bagaço-dacana (adaptado de Hahn-Hägerdal et al, 2006). ${ }^{4}$ 3

Figura 2. Métodos analíticos utilizados em metabolômica (adaptado de Abdelnur et. al., 2014) ${ }^{21}$ 5

Figura 3. Diagrama de blocos de um espectrômetro de massas (adaptado de Skoog et al, 2001). ${ }^{33}$ 7

Figura 4. Produção de íons por fonte de ionização ESI (adaptado de Hoffmann e Stroobant, 2007) ${ }^{36}$. 8

Figura 5. Esquema de um analisador triplo quadrupolo (adaptado de Chiaradia et $a)^{35}$ 10

Figura 6. Tipos de cromatografia por troca iônica (IEC): catiônica e aniônica respectivamente (adaptado de Acikara). ${ }^{51}$ 15

Figura 7. Fluxo de trabalho do preparo de amostra aplicado em metabolômica (adaptado de Villas-Bôas et al, 2005). ${ }^{28}$ 18

Figura 8. Visão geral das principais reações metabólicas no metabolismo do carbono central (adaptado de Bergdahl et al, 2012). ${ }^{61}$ 20

Figura 9. Gráfico de fermentação microaeróbica da levedura Scheffersomyces stipitis. 36

Figura 10. Banho termostático com os tubos falcon contendo a solução tampão de metanol. 37

Figura 11. Estrutura química dos padrões analisados 40

Figura 12. Espectro de massas por ESI(-)-MS da mistura dos padrões de metabólitos (ácido málico - L-MAL, ácido alfacetoglutárico - AKG, gliceraldeído3-fosfato - GAP, fosfo(enol)piruvato - PEP, glicose-6-fosfato - G6P, frutose-6fosfato - F6P, ribose-5-fosfato - R5P, ribulose-5-fosfato - Ru5P).

Figura 13. Espectros de massas por ESI(-)-MS/MS do metabólito DHAP: a) energia de colisão $10 \mathrm{eV}$ b) energia de colisão $18 \mathrm{eV}$. c) Espectro de massas por ESI(-)-MS/MS do metabólito PEP com energia de colisão $10 \mathrm{eV}$. 44

Figura 14. Espectro de massas por ESI(-)-MS/MS do padrão ácido alfa cetoglutárico $(m / z 145)$ (energia de colisão $15 \mathrm{eV})$. 
Figura 15. Espectro de massas por ESI(-)-MS/MS do padrão acetil co-a $(\mathrm{m} / \mathrm{z}$ 808) (energia de colisão $40 \mathrm{eV}$ ).

Figura 16. Espectro de massas por ESI(-)-MS/MS do padrão ácido oxaloacético $(m / z 131)$ (energia de colisão $6 \mathrm{eV})$

Figura 17. Espectro de massas por ESI(-)-MS/MS do padrão ácido málico $(\mathrm{m} / \mathrm{z}$ 133) (energia de colisão $10 \mathrm{eV}$ ).

Figura 18. Espectro de massas por ESI(-)-MS/MS do padrão dihidroxiacetona fosfato $(m / z 169)$ (energia de colisão $18 \mathrm{eV})$.

Figura 19. Espectro de massas por ESI(-)-MS/MS do padrão fosfo(enol)piruvato $(\mathrm{m} / \mathrm{z} 167)$ (energia de colisão $10 \mathrm{eV}$ ).

Figura 20. Espectro de massas por ESI(-)-MS/MS do padrão frutose-6-fosfato $(\mathrm{m} / \mathrm{z} 259)$ (energia de colisão $18 \mathrm{eV}$ ). 50

Figura 21. Espectro de massas por ESI(-)-MS/MS do padrão glicose-6-fosfato $(\mathrm{m} / \mathrm{z}$ 259) (energia de colisão $20 \mathrm{eV}$ ). 50

Figura 22. Espectro de massas por ESI(-)-MS/MS do padrão glicose $(\mathrm{m} / z$ 179) (energia de colisão $18 \mathrm{eV}$ )

Figura 23. Espectro de massas por ESI(-)-MS/MS do padrão gliceraldeído-3fosfato $(\mathrm{m} / \mathrm{z} 169)$ (energia de colisão $18 \mathrm{eV}$ ).

Figura 24. Espectro de massas por ESI(-)-MS/MS do padrão glicerol $(\mathrm{m} / z$ 91) (energia de colisão $18 \mathrm{eV}$ )

Figura 25. Espectro de massas por ESI(-)-MS/MS do padrão piruvato de sódio $(\mathrm{m} / \mathrm{z} 87)$ (energia de colisão $8 \mathrm{eV}$ ). 52

Figura 26. Espectro de massas por ESI(-)-MS/MS do padrão ribulose-5-fosfato ( $m / z$ 229) (energia de colisão $20 \mathrm{eV}$ ). 53

Figura 27. Espectro de massas por ESI(-)-MS/MS do padrão ribose-5-fosfato $(\mathrm{m} / \mathrm{z} 229)$ (energia de colisão $20 \mathrm{eV}$ ). 53

Figura 28. Espectro de massas por ESI(-)-MS/MS do padrão xilose $(m / z$ 149) (energia de colisão $14 \mathrm{eV}$ ).

Figura 29. Espectro de massas por ESI(-)-MS/MS do padrão xilitol $(m / z$ 151) (energia de colisão $20 \mathrm{eV}$ )

Figura 30. Espectro de massas por ESI(-)-MS/MS do padrão xilulose $(\mathrm{m} / \mathrm{z}$ 149) (energia de colisão $14 \mathrm{eV}$ ). 
Figura 31. Cromatogramas da mistura de 14 padrões de metabólitos: a) FM: A: $\mathrm{NH}_{4} \mathrm{OH} 0,1 \%$ B: $\mathrm{ACN}+\mathrm{NH}_{4} \mathrm{OH}$ 0,1\%. b) FM: A: $\mathrm{ACN}: \mathrm{H}_{2} \mathrm{O}(50: 50)+\mathrm{AcNH}_{4}$ 10 mM B: $A C N: \mathrm{H}_{2} \mathrm{O}(90: 10)+$ AcNH4 10mM. c) FM: A: $\mathrm{ACN}: \mathrm{H}_{2} \mathrm{O}(90: 10)+$ FormNH $5 \mathrm{mM}+\mathrm{NH}_{4} \mathrm{OH}$ 0.1\% B: $\mathrm{ACN}: \mathrm{H}_{2} \mathrm{O}(10: 90)+$ FormNH4 $5 \mathrm{mM}+$ $\mathrm{NH}_{4} \mathrm{OH} 0,1 \%$. 57

Figura 32. Cromatogramas de íons totais (TIC) dos padrões individuais: a) ácido málico - L-MAL; b) frutose-6-fostato - F6P; c) glicose-6-fosfato - G6P. . . 58 Figura 33. Cromatogramas de íons totais (TIC) dos padrões individuais: a) Xilulose e b) Glicose. 59

Figura 34. Cromatograma dos canais de MRM do método HILIC utilizando como FM (A: Hidróxido de amônio 0,1\% e B: Acetonitrila + Hidróxido de amônio 0,1\%) para a mistura de cinco padrões de metabólitos: a) glicose 179,1>58,9, b) xilitol $151>58.9$, c) xilulose $149>59$, d) xilose 148,9 > 59, e) glicerol $91>$ 59,1 60

Figura 35. Cromatograma de íons totais (TIC) do método HILIC utilizando como FM (A: Hidróxido de amônio 0,1\% e B: Acetonitrila + Hidróxido de amônio $0,1 \%$ ) dos compostos: a) xilulose e b) xilose.

Figura 36. Estrutura das moléculas dos reagentes do par iônico. a)

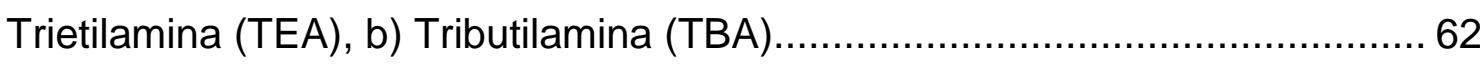

Figura 37. Cromatograma da mistura de oito padrões de metabólitos: (a) Trietilamina $5 \mathrm{mM}$ + ácido fórmico $20 \mathrm{mM}$, (b) Trietilamina $10 \mathrm{mM}$ + ácido fórmico $20 \mathrm{mM}$...

Figura 38. Cromatogramas dos íons totais (TIC) da mistura de oito padrões de metabólitos por ESI(-)-MS/MS no modo MRM: A: TBA 2 mM + Ácido Acético 4 mM, B: (a) Metanol (b) Acetonitrila (o eixo horizontal é o tempo de retenção em minutos). 64

Figura 39. Cromatogramas de íons totais (TIC) da mistura de oito padrões de metabólitos FM: TBA 2 mM + Ácido Acético 4 mM, nos modos: (a) Isocrático, (b) Gradiente. (eixo horizontal é o tempo de retenção em minutos). 65

Figura 40. Cromatogramas de íons totais (TIC) da mistura de oito padrões de metabólitos: (a) fase móvel: TBA $2 \mathrm{mM}+$ Ácido Acético $3 \mathrm{mM}, \mathrm{pH}=5.1$ (b) fase 
móvel: TBA $2 \mathrm{mM}$ + Ácido Acético $4 \mathrm{mM}, \mathrm{pH}=4.8$ (c) fase móvel: TBA $2 \mathrm{mM}+$

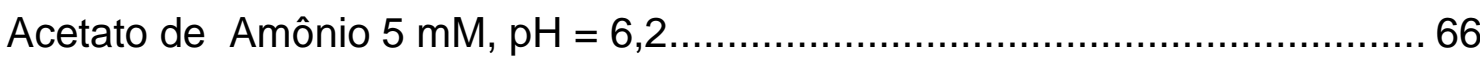

Figura 41. Cromatogramas de íons totais (TIC) (a) fase móvel: TBA $2 \mathrm{mM}+$ Ácido Acético $4 \mathrm{mM}+5 \% \mathrm{MeOH}$ (b) fase móvel: TBA $5 \mathrm{mM}+$ Ácido Acético 10 mM (c) fase móvel: TBA 10mM + Ácido Acético $15 \mathrm{mM}$. 68

Figura 42. Cromatogramas de íons totais (TIC) da mistura de catorze padrões de metabólitos em modo isocrático, à temperatura ambiente: (a) Ácido Trifluoroacético 0,05\%, (b) Ácido fórmico 0,1\%............................................ 70

Figura 43. Cromatogramas de íons totais (TIC) da mistura de catorze padrões de metabólitos, à temperatura ambiente. (a) $\mathrm{A}$ : $90 \%$ de ácido fórmico $0,1 \%$, $B$ : $10 \%$ de acetonitrila (b) $100 \%$ de ácido fórmico $0,1 \%$. 71

Figura 44. Cromatogramas de íons totais (TIC) da mistura de oito padrões de metabólitos em modo isocrático, $\mathrm{FM}$ ácido fórmico $0,1 \%$. (a) $45^{\circ} \mathrm{C}$ (b) $65^{\circ} \mathrm{C} \ldots 72$ Figura 45 Visão geral das principais reações metabólicas no metabolismo do carbono central. Padrões circulados na cor vermelha podem ser identificados pelo método IPC, padrões circulados na cor amarela foram identificados pelo 73 Figura 46. Cromatogramas dos canais MRM dos metabólitos produzidos pela levedura S. passalidarum analisados pelo método IPC. (a) Volume de amostra

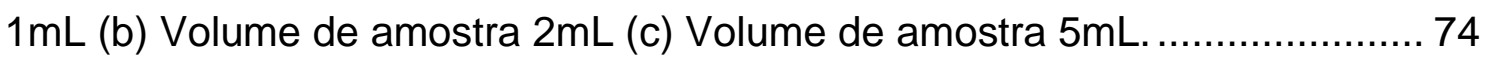

Figura 47. Cromatogramas dos canais MRM dos metabólitos produzidos pela levedura S. stipitis analisados pelo método IPC. Metabólitos intracelulares identificados: a) ácido málico, b) fosfo(enol)piruvato, c) frutose-6-fosfato e d) glicose-6-fosfato. 75

Figura 48. Cromatogramas dos canais MRM dos metabólitos produzidos pela levedura $S$. passalidarum analisados pelo método IPC. Metabólitos intracelulares identificados: a) glicose-6-fosfato, b) frutose-6-fosfato e c) ácido málico 76

Figura 49. Cromatogramas dos canais MRM dos metabólitos produzidos pela levedura S. stipitis analisados pelo método HILIC. Metabólitos identificados: a) xilitol, b) xilulose, c) xilose e d) glicerol. 
Figura 50. Cromatogramas dos canais MRM dos metabólitos produzidos pela levedura $S$. spathaspora analisados pelo método HILIC. Metabólitos identificados: a) xilose, b) xilitol e c) glicerol............................................... 77

Figura 51. Visão geral das principais reações metabólicas no metabolismo do carbono central. Compostos circulados em vermelho foram detectados nas amostras de duas leveduras analisadas $S$. stipitis e $S$. spathaspora. 79 
INTRODUÇÃO 


\section{INTRODUÇÃO}

\subsection{Etanol de Segunda Geração (2G)}

O etanol vem sendo considerado um substituinte em potencial para os combustíveis derivados do petróleo e uma solução sustentável para o problema da emissão de gases poluentes. $O$ aumento na demanda por fontes de energia alternativa e as preocupações com os impactos ambientais tem motivado o desenvolvimento de tecnologias para a produção de combustíveis a partir da biomassa vegetal. ${ }^{1-6}$

A biomassa é basicamente matéria orgânica renovável (espécies oleoginosas, grãos, resíduos de agricultura, entre outros), rica em açúcar, ou em compostos que possam ser convertidos em açúcar, por exemplo, a celulose. ${ }^{7}$ Os países que lideram o mercado mundial da produção de etanol, Estados Unidos e Brasil, utilizam principalmente o milho e a cana-de-açúcar respectivamente, como fontes de biomassa. ${ }^{1,4,8}$

Apesar da produção de etanol de primeira geração (1G) ser um processo bem estabelecido no Brasil, ainda há espaço para crescimento e redução de custos. A biomassa é responsável por $40-70 \%$ do custo total do processo para a produção de etanol $1 \mathrm{G}$, que é dependente da localização geográfica e das variações nas safras. ${ }^{9}$ Além disso, a competição pelo uso da terra para a produção de alimentos gera outros impactos como excesso no uso de fertilizantes nitrogenados, e o aumento de áreas desmatadas. ${ }^{8}$

Durante o processo de produção do etanol $1 \mathrm{G}$, a partir da cana-deaçúcar, uma grande quantidade de bagaço é produzida. Em geral, uma tonelada de cana-de-açúcar, gera, em média, $280 \mathrm{Kg}$ de bagaço, parte deste resíduo é utilizado pelas refinarias como insumo para a produção de energia. $O$ bagaço de cana-de-açúcar é composto majoritariamente por lignina (20-30\%), celulose (40-45\%) e hemiceluloses (30-35\%) ${ }^{9}$. A lignina é formada por álcoois aromáticos, enquanto que a celulose e a hemicelulose são constituídas 
principalmente por monossacarídeos, hexoses e pentoses, sendo a xilose, o açúcar de cinco carbonos, mais abundante da biomassa residual. ${ }^{7-9}$

Dado a alta concentração de açúcares fermentáveis, como a glicose e a xilose, no bagaço da cana-de-açúcar, e considerando-se sua vasta disponibilidade na indústria, faz-se necessário o desenvolvimento de tecnologias que utilizem esta biomassa para a produção de etanol, o chamado etanol de segunda geração $(2 \mathrm{G})$.

Biocombustíveis gerados a partir de biomassas lignocelulósicas, como o etanol de segunda geração $(2 \mathrm{G})$, agregam valor à matéria-prima e são uma alternativa promissora para minimizar os impactos decorrentes da produção deste produto na agricultura. ${ }^{1-6}$ Além disso, o processo de produção de etanol $2 G$ pode compartilhar parte da infraestrutura onde a produção de etanol de primeira geração é realizada, tornando este procedimento ainda mais viável para a indústria. ${ }^{10}$

O processo de transformação do material lignocelulósico a etanol consiste basicamente em quatro etapas: pré-tratamento, hidrólise, fermentação e separação/destilação do produto (Figura 1). ${ }^{7-10}$ Os açúcares presentes na celulose e hemicelulose, são liberados do polímero, através das etapas de prétratamento e hidrólise enzimática e, em seguida são fermentados a etanol. ${ }^{4}$

As hexoses podem ser fermentadas e convertidas a etanol, já a xilose, não é aproveitada, devido à incapacidade da levedura Saccharomyces cerevisiae, microrganismo mais empregado na indústria de etanol de primeira geração, de converter pentoses a etanol. ${ }^{4,6}$ 


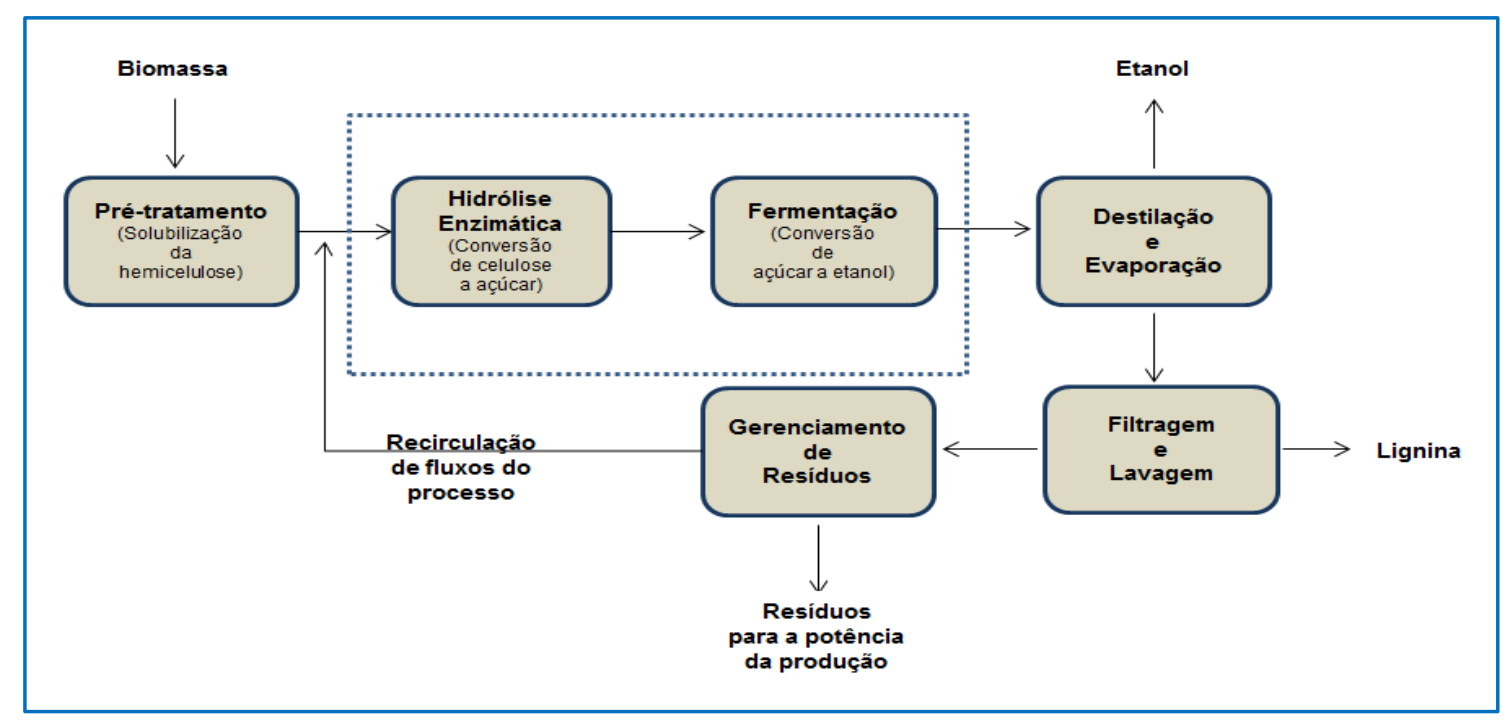

Figura 1. Esquema da produção de etanol combustível a partir do bagaço-dacana (adaptado de Hahn-Hägerdal et al, 2006). ${ }^{4}$

Tendo em vista a importância da utilização da xilose para aumentar o rendimento da produção de etanol $2 \mathrm{G}$, diversos estudos têm buscado 0 desenvolvimento de processos industriais para produção de etanol a partir deste substrato. Dentre as estratégias utlizadas estão: i) o uso da engenharia genética para o melhoramento de linhagens de $S$. cerevisiae, e ii) a identificação de espécies naturalmente fermentadoras de xilose, que possam resistir aos compostos tóxicos presentes no hidrolisado lignocelulósico. ${ }^{11-13} \mathrm{~A}$ construção de linhagens recombinantes capazes de fermentar xilose permitirá a fusão de processos de produção de etanol de primeira geração com a produção de etanol $2 \mathrm{G}$. Isto resultará em uma produção com menores custos, maior aproveitamento da matéria-prima e melhor rendimento industrial. ${ }^{11-14}$

O desenvolvimento de tecnologias eficientes capazes de fornecer informações sobre o metabolismo de leveduras fermentadoras de xilose pode facilitar a compreensão e a identificação dos fatores limitantes para conversão de xilose a etanol. A metabolômica tem sido mencionada na literatura como uma estratégia valiosa para identificar o metabolismo celular de uma espécie, uma vez que promove uma análise abrangente, qualitativa e quantitativa dos metabólitos presentes em um sistema biológico. ${ }^{15-17}$ 
O estudo do metaboloma de um microrganismo permite uma visão geral das funções celulares e fisiológicas, e se combinada com outras ciências ômicas como genômica e transcriptômica, pode auxiliar na identificação de alvos moleculares a serem utilizados no desenvolvimento de microrganismos fermentadores de xilose mais eficientes. ${ }^{15}$

\subsection{Metabolômica}

O Metaboloma é definido como um conjunto de moléculas de baixo peso molecular presentes em um organismo - os metabólitos. ${ }^{16,17} \mathrm{O}$ tamanho do metaboloma varia significativamente de um organismo para outro. A levedura Saccharomyces cerevisiae, por exemplo, contém aproximadamente 600 metabólitos identificados, enquanto que as plantas possuem 200.000 metabólitos primários e secundários. ${ }^{15,16}$ Estas moléculas são transformadas quimicamente durante o metabolismo celular atuando como intermediários e produtos das reações metabólicas, além de serem necessárias para manutenção, crescimento e funcionamento das células. ${ }^{18}$ Uma variação no sistema biológico pode ser identificada através de alterações no fluxo dos metabólitos. ${ }^{17}$

O termo Metabolômica foi introduzido nos anos 2000 por Dr. Oliver Fieh e colaboradores, e refere-se a uma análise abrangente (qualitativa e quantitativa) de todos os metabólitos em um sistema celular. É uma ciência multidisciplinar que engloba a química orgânica, química analítica, biologia, bioinformática e biotecnologia. ${ }^{19,20}$

A abordagem metabolômica possui dois métodos complementares: targeted e untargeted. O método targeted consiste na quantificação de metabólitos alvo, cujo objetivo é responder a questões bioquímicas ou hipóteses específicas de uma via metabólica em particular. ${ }^{15} \mathrm{~A}$ análise untargeted baseia-se no perfil metabólico total de um organismo, e tem por objetivo medir, simultaneamente, a maior quantidade possível de metabólitos em uma amostra biológica. ${ }^{19}$ 
A identificação e quantificação de uma variedade significativa de metabólitos (polares, não-polares, voláteis, entre outros) provenientes do extrato celular, com concentração estimada na faixa de pmol a mmol, torna necessário a utilização de metodologias específicas capazes de analisar simultaneamente uma grande quantidade de metabólitos com alta sensibilidade e seletividade. ${ }^{17,18}$

A figura 2 apresenta as principais técnicas analíticas utilizadas em metabolômica. A ressonância magnética nuclear (do inglês, Nuclear Magnetic Resonance - NMR) e a espectrometria de massas (do inglês, Mass Spectrometry - MS), estão entre as principais técnicas mais comumente utilizadas nesta área. $^{15,21}$ No entanto, embora a NMR seja uma técnica altamente seletiva possui baixa sensibilidade, já a espectrometria de massas oferece boa seletividade aliada a sensibilidade.

A espectrometria de massas pode ser realizada de forma direta, com diferentes fontes de ionização e analisadores, e/ou acopladas a técnicas de separação como eletroforese capilar (do inglês, Capillary Electrophoresis - CE), cromatografia gasosa (do inglês, Gas Chromatography - GC) e cromatografia líquida (do inglês, Liquid Chromatography - LC). ${ }^{22}$

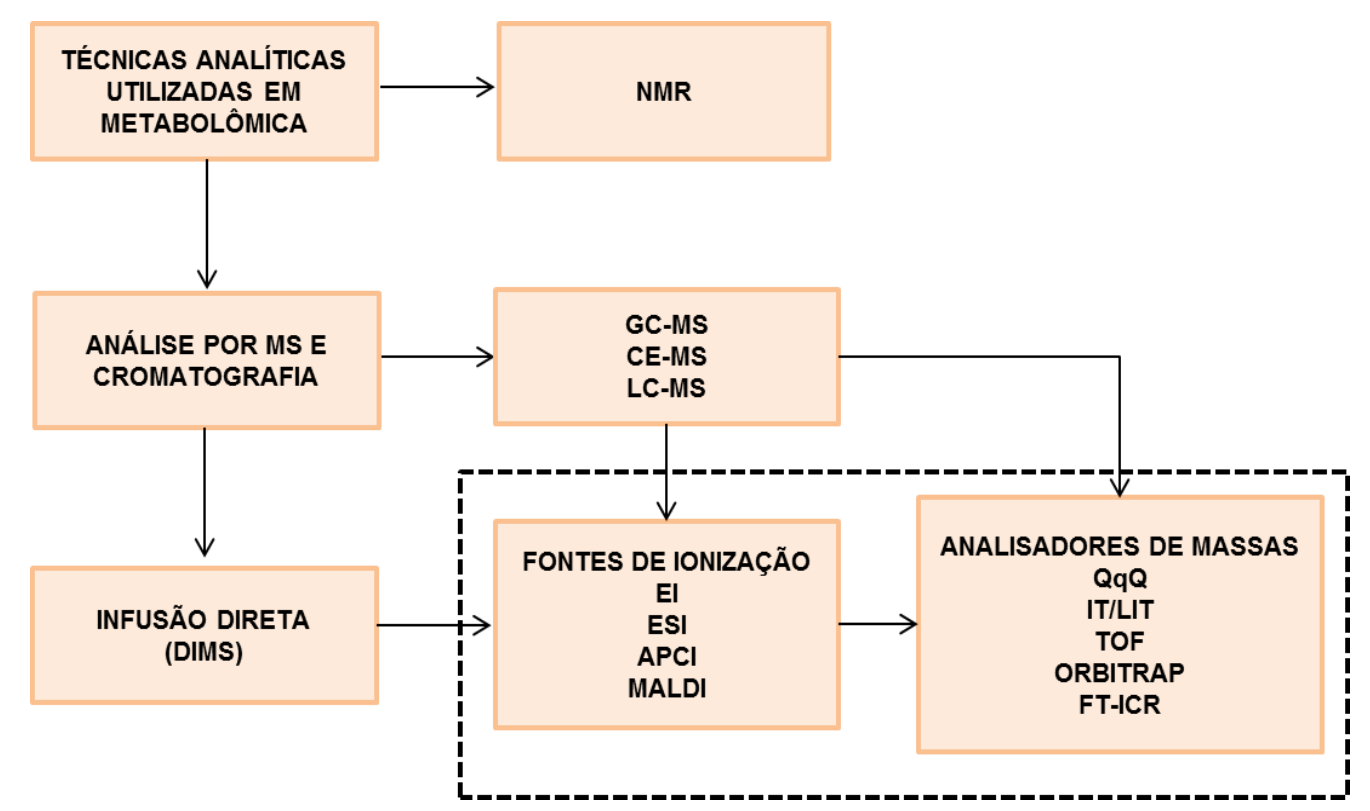

Figura 2. Métodos analíticos utilizados em metabolômica (adaptado de Abdelnur et. al., 2014) ${ }^{21}$ 
A preparação da amostra é uma das etapas cruciais para análises de metabolômica. Para a metabolômica de microrganismos é necessária à utilização de um processo rápido que interrompa instantaneamente as reações enzimáticas, capaz de separar os metabólitos extracelulares da biomassa. A última etapa consiste em uma extração eficiente dos metabólitos do meio intracelular evitando-se ao máximo as perdas por degradação ou reação bioquímica. A temperatura do solvente deve ser controlada e os processos de incubação, centrifugação e concentração da amostra, otimizados. Em geral, o protocolo para análise dos metabólitos intracelulares e, portanto, para um experimento de metabolômica, envolve 0 desenvolvimento de métodos analíticos, preparo de amostra, análise dos metabólitos, processamento e interpretação dos dados. ${ }^{21}$

\subsubsection{Métodos Analíticos}

\subsubsection{Espectrometria de massas (MS - Mass Spectrometry)}

A espectrometria de massas (MS) é uma técnica de deteç̧ão amplamente utilizada para a identificação de moléculas de diferentes pesos moleculares e estruturas que usa a medida da relação massa/carga $(\mathrm{m} / \mathrm{z})$ de seus íons. As medidas por MS são feitas a partir de analitos ionizados e ejetados para dentro de um espectrômetro de massas, os íons separados são então detectados e um gráfico contendo a intensidade do sinal gerado pelo íon versus $\mathrm{m} / \mathrm{z}$ é produzido pelo sistema de dados. ${ }^{33} \mathrm{Na}$ figura 3 é apresentado um diagrama de blocos com os principais componentes de um espectrômetro de massas. 


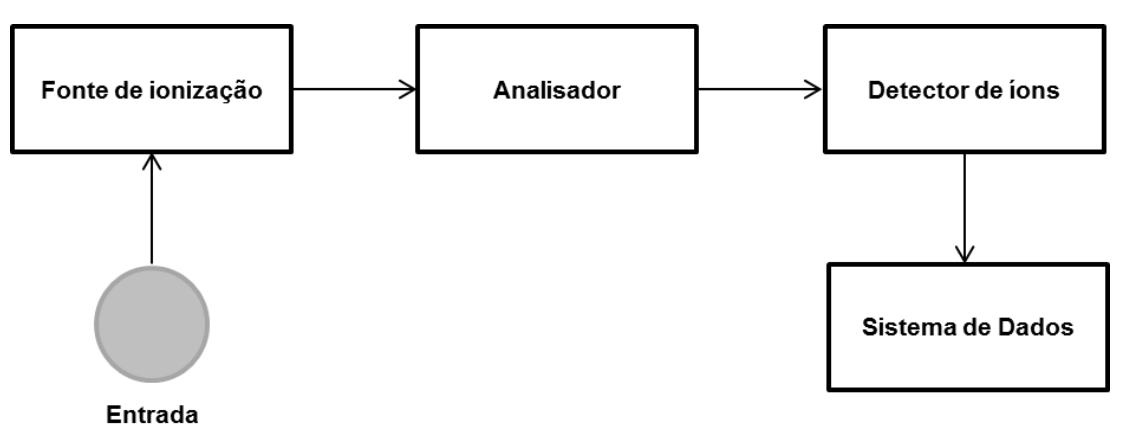

Figura 3. Diagrama de blocos de um espectrômetro de massas (adaptado de Skoog et al, 2001). ${ }^{33}$

A fonte de ionização gera íons na fase gasosa, a partir de moléculas neutras ou de moléculas carregadas. Diferentes tipos de fontes de ionização estão disponíveis para o uso em MS. As principais fontes empregadas na análise em metabolômica são: ionização por elétrons (eletron ionization - El), ionização por eletrospray (electrospray ionization - ESI), ionização à pressão atmosférica (Atmospheric-Pressure Chemical Ionization - APCl) e dessorção/ionização a laser assistida por matriz (Matrix Assisted Laser Desorption/lonization - MALDI). ${ }^{34}$

Neste trabalho foi utilizada a fonte de ionização por electrospray acoplada a MS (ESI-MS). Esta é uma técnica de ionização branda, que produz íons carregados em solução produzidos através da aplicação de um campo elétrico, sob pressão atmosférica, gerado por uma diferença de potencial. ${ }^{36} \mathrm{~A}$ principal vantagem do electrospray é que a dessolvatação ocorre gradualmente em temperaturas relativamente baixas $\left(\leq 80^{\circ} \mathrm{C}\right)$, de forma a minimizar a fragmentação das moléculas na fonte. Assim, muitos dos íons gerados na fase gasosa mantém exatamente a mesma estrutura e carga das espécies em solução. ${ }^{38}$ Além disso as amostras a serem analisadas são introduzidas em solução, o que faz com que seja possível o acoplamento com muitas técnicas de separação, como a cromatografia líquida.

A produção de íons requer, essencialmente, dois passos: dispersão de gotas altamente carregadas, seguida por condições que permitam a evaporação da gota. Uma fonte de alta tensão entra em contato com a solução 
contendo os analitos. Esta solução é transmitida através do capilar, onde é aplicado um potencial positivo ou negativo forçando um processo de oxiredução e, consequentemente, a formação de algumas espécies sem seus contra-íons. Assim, a gota sendo formada na ponta do capilar constituirá de íons positivos ou negativos, dependendo do potencial aplicado. Conforme a densidade de carga aumenta na gota, presa à ponta do capilar, o campo elétrico formado entre o capilar e o contra-eletrodo aumenta, provocando uma deformação na gota. A gota ganha forma de um cone, o qual é denominado de cone de Taylor. Quando a densidade de carga supera a tensão superficial, a gota se desprende do capilar subdividindo-se (Figura 4). Este processo é dependente da magnitude do campo elétrico, da tensão superficial do solvente e da condutividade da solução. ${ }^{38}$

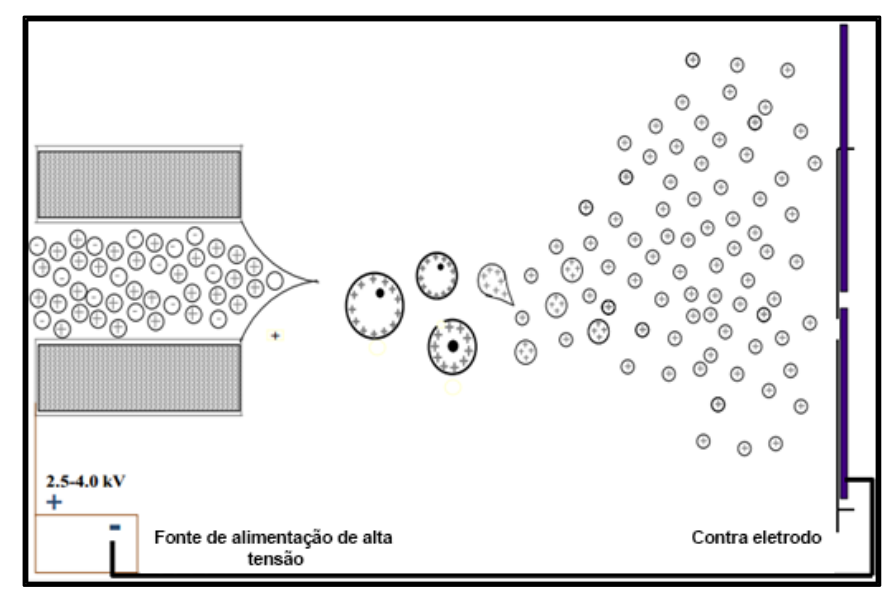

Figura 4. Produção de íons por fonte de ionização ESI (adaptado de Hoffmann e Stroobant, 2007) ${ }^{36}$.

Entre os analisadores mais utilizados em MS para análise em metabolômica estão: quadrupolo (quadrupole $-Q$ ), armadilhas de íons (Ion Trap), tempo-de-vôo (time-of-flight - TOF), Orbitrap e ressonância ciclotrônica de íons com transformada de Fourier (Fourier transform ion cyclotron - ICRFT).

Os analisadores quadrupolares utilizam campos elétricos oscilantes, gerados por quatro barras metálicas (eletrodos), para estabilizar ou 
desestabilizar seletivamente os íons, durante sua passagem pelo centro do quadrupolo, de acordo com seus valores de $\mathrm{m} / \mathrm{z}$. O quadrupolo funciona como um filtro. Isso permite que os íons de diferentes valores de $\mathrm{m} / \mathrm{z}$ cheguem com tempos diferentes ao detector e, desta forma, possam ser diferenciados. ${ }^{35}$

Os analisadores ion trap capturam os íons através de um campo elétrico que mantém os íons em uma órbita estável em seu interior. Um potencial RF (radio frequência) é aplicado e os íons são então desestabilizados e expelidos para fora do analisador, de acordo com seus valores de $m / z^{35-37}$

Os analisadores tempo de vôo baseiam-se no princípio de que íons com mesma carga têm energias cinéticas iguais e a velocidade de cada íon será inversamente proporcional à raiz quadrada da sua massa. Logo, se dois íons com mesma carga e massas diferentes, forem acelerados através de um campo elétrico com potencial constante, suas velocidades serão dependentes de suas massas e eles atingirão o detector com "tempos de vôo" diferentes. ${ }^{36,37}$

$\mathrm{O}$ analisador ICR-FT e o Orbitrap operam sob a ação de um campo magnético. Este ambiente mantém os íons em movimento circular e oscilatório. Quando excitados por pulsos de RF os íons descrevem órbitas coerentes e, através dos detectores, os sinais elétricos dos íons são medidos. A frequência de um íon em sua órbita é determinada pela sua razão $\mathrm{m} / \mathrm{z}^{36,37}$

\subsubsection{Espectrometria de massas Tandem}

A espectrometria de massas do tipo Tandem ou MS/MS pode ser entendida como a espectrometria de massas sequencial, sendo necessário equipamentos apropriados que permitam a seleção específica do íon desejado. O espectrômetro de massas com analisador do tipo "triplo quadrupolo" (QqQ) (Figura 5) tem sido o mais utilizado para a quantificação de metabólitos, pois oferece boa sensibilidade e reprodutibilidade. ${ }^{40}$

Nos analisadores do tipo triplo quadrupolo (QqQ), um analisador quadrupolar $(Q)$ é acoplado a uma câmara de colisão preenchida com um gás inerte (q), a qual é conectada a um segundo quadrupoo (Q). Este tipo de analisador de massas pode ser operado em diferentes modos, como: 
varredura, tandem (MS/MS) e monitoramento de reações múltiplas (Multiple Reaction Monitoring - MRM).

No modo varredura, o íon precursor é selecionado no primeiro quadrupolo (Q1), e os outros dois quadrupolos funcionam como direcionadores dos íons até o sistema de detecção.

No modo tandem (MS/MS), o íon precursor é selecionado no primeiro quadrupolo (Q1), é fragmentado no segundo quadrupolo (q) por dissociação induzida por colisão (“collision-induced dissociation” - CID) com um gás inerte. Em seguida, todos os íons fragmentos são detectados no terceiro quadrupolo (Q3). ${ }^{35}$

A alta especificidade analítica é conseguida quando se utiliza o modo MRM. Nesta técnica, a energia de colisão e a razão $\mathrm{m} / \mathrm{z}$ do íon fragmento são pré-otimizados para cada analito a fim de obter o sinal mais intenso. O primeiro quadrupolo seleciona o íon precursor de interesse, este é então fragmentado no segundo quadrupolo, e o terceiro quadrupolo direciona o íon fragmento préotimizado. $^{40}$

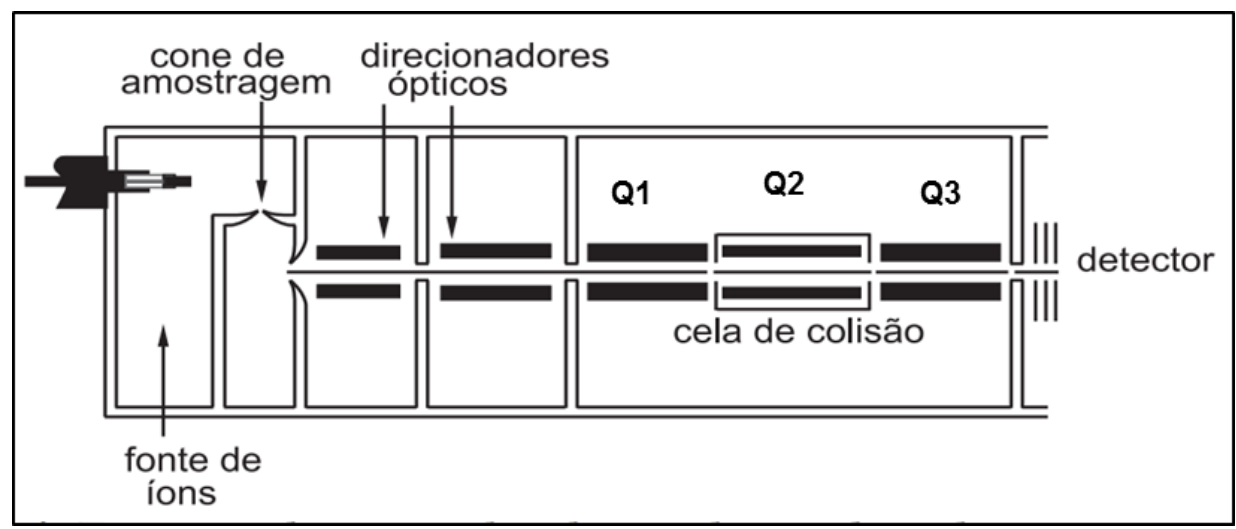

Figura 5. Esquema de um analisador triplo quadrupolo (adaptado de Chiaradia et al) 35 


\subsubsection{Métodos cromatográficos acoplados a espectrometria de massas}

A análise de MS por infusão direta (DIMS) pode ser utilizada para identificação estrutural de uma vasta gama de compostos químicos. A alta sensibilidade da MS permite níveis de detecção de metabólitos na faixa de picomols e femtomols. ${ }^{34}$ No entanto, análises por DIMS não são capazes de distinguir algumas substâncias com a mesma massa molar, como os isômeros estruturais ou esteroisômeros. Desta forma técnicas de separação acopladas a MS tem sido utilizada como estratégia em metabolômica. ${ }^{41,42}$

Entre as vantagens do uso da MS acoplada a técnicas cromatográficas estão: redução do efeito de matriz e supressão iônica, possibilidade de identificação de isômeros, e maior precisão na quantificação dos metabólitos individuais. A escolha do método analítico irá depender do analito de interesse e do tipo da amostra. ${ }^{42}$

Os principais métodos de separação acoplados a MS utilizados na análise de amostras quimicamente complexas, são: cromatografia gasosa (GCMS), cromatografia líquida (LC-MS) e cromatografia eletroforese capilar (CE$M S) .{ }^{40-42}$ Os analitos separados são introduzidos no espectrômetro em estado gasoso (GC-MS) ou em solução (LC-MS e CE-MS). No caso de soluções, a introdução da amostra no espectrômetro pode ocorrer de duas formas: modo off line, em que as frações eluídas na separação cromatográfica são coletadas manualmente em um frasco para posterior injeção ou modo on line, em que o cromatográfo é conectado diretamente ao espectrômetro de massas e os espectros são adquiridos enquanto os compostos das misturas são eluídos. ${ }^{40-42}$

A cromatografia gasosa é uma técnica analítica de separação dos componentes de uma amostra, bastante sensível e abrangente, em que os analitos devem ser voláteis e termicamente estáveis. Alguns metabólitos de natureza polar precisam ser quimicamente derivatizados para serem analisados por GC-MS. Este procedimento aumenta o tempo e a complexidade do preparo de amostra. ${ }^{42} \mathrm{~A}$ fase móvel é constituída por um gás inerte, em 
geral, nitrogênio ou hélio, e a fase estacionária por um líquido ou sólido contido dentro da coluna cromatográfica. ${ }^{33,36}$.

A cromatografia por eletroforese capilar é uma técnica de separação baseada na migração diferenciada de compostos iônicos ou ionizáveis em um campo elétrico. ${ }^{43}$ Esta técnica cromatográfica acoplada a um detector sensível como o espectrômetro de massas aumenta a seletividade e a sensibilidade do método. Analitos que apresentam pequenas variações no tempo de migração, ou até mesmo que migram com a mesma velocidade, podem ser identificados. Neste cenário, a CE-MS vem emergindo como uma ferramenta de grande impacto em bioanalítica. Porém ainda são necessários grandes investimentos em pesquisa e desenvolvimento para atingir sua plena capacidade tecnológica.

A cromatografica líquida é uma técnica versátil e amplamente utilizada para a separação de uma grande variedade de compostos orgânicos e inorgânicos, através da diferença de afinidade que estes apresentam em relação à fase móvel e à fase estacionária. A fase móvel é um solvente líquido, que através de pressões elevadas é forçado a passar através de colunas fechadas que contém partículas muito finas (fase estacionária), capazes de proporcionar separações com alta resolução, aliada a rapidez e seletividade. Os analitos são eluídos da coluna cromatográfica em tempos diferentes de acordo com suas propriedades físico-químicas e são então detectados no espectrômetro de massas. A intensidade ou área dos picos é proporcional à sua concentração.

Buscher et al (2009) ${ }^{45}$ compararam métodos analíticos empregando GC-MS, CE-MS e LC-MS para a quantificação de metabólitos, e observaram que bons resultados relacionados a sensibilidade e seletividade são conseguidos com a utilização da técnica de GC-MS. No entanto a desvantagem do método encontra-se na etapa de preparo de amostra, o qual é trabalhosa e demorada devido à etapa de derivatização necessária para análise da maior parte dos metabólitos, que são quase sempre termo-lábeis e não-voláteis. Além disso, concluíram que embora a técnica CE-MS apresente boa sensibilidade, não é robusta para análises de rotina de extratos biológicos, sendo sua aplicação limitada para valores de concentração muito baixos. Por 
outro lado, a técnica LC-MS mostrou ser uma ótima ferramenta de trabalho por ser de fácil utilização, sensível, seletiva, robusta para a matriz biológica, e robusta na operação de rotina.

\subsubsection{Cromatografia Líquida de Ultra Alta Eficiência acoplada à espectrometria de massas (UHPLC- MS)}

A cromatografia líquida de Ultra Alta Eficiência acoplada à espectrometria de massas (UHPLC-MS) é uma técnica de separação que permite o desenvolvimento de métodos analíticos para um maior número de analitos em concentrações mais baixas e matrizes mais complexas. A utilização de colunas cromatrográficas com partículas $\leq 2 \mu \mathrm{m}$, aumenta a resolução e a detectabilidade da técnica, e diminui o tempo de análise e o consumo de solvente. $\mathrm{O}$ aumento significativo na pressão cromatográfica exigiu o desenvolvimento de instrumentação adequada, capaz de operar nestas condições.

Uma variedade de métodos podem ser desenvolvidos em função dos diferentes modos de separação disponíveis para esta técnica. No presente trabalho, foram testadas três condições de separação descritas a seguir: cromatografia por interação hidrofílica, cromatografia por pareamento iônico, e cromatografia por troca iônica.

A cromatografia por interação hidrofílica (do inglês hydrophilic interaction liquid chromatography - HILIC) envolve o uso de fases estacionárias polares como a sílica quimicamente modificada, ligadas a grupos orgânicos como: amina, amida, diol, ciano entre outros ${ }^{47}$ Os compostos são separados principalmente por uma fase móvel orgânica e os analitos são eluídos em ordem decrescente de hidrofobicidade. ${ }^{49}$

O mecanismo de separação da cromatografia HILIC é complexo e ainda pouco entendido. Tang et al $(2014)^{48}$ propõem que as moléculas de água são atraídas pelos grupos polares dos diferentes tipos de fase estacionária formando uma camada aquosa sobre a superfície. A partição dos analitos entre 
a fase móvel (hidrofóbica) e a camada aquosa imobilizada constitui o maior mecanismo de retenção da HILIC. ${ }^{47-48}$

A cromatografia por pareamento iônico (ion pair chromatography- IPC) utiliza fase estacionária hidrofóbica, e como fase móvel um solvente compatível com MS para separar compostos iônicos pela adição de um sal inorgânico contendo um contra-íon orgânico que pode ser um sal de amônio quaternário ou um alquilsulfonato. Estes compostos são descritos na literatura como reagentes de pareamento iônico (ion pair - IP). ${ }^{33}$

O mecanismo de separação da IPC basea-se na adsorção da molécula do reagente de pareamento iônico na interface formada entre a fase estacionária e a fase móvel. A parte hidrofóbica da cadeia do reagente IP é adsorvida na fase estacionária, enquanto que a parte carregada da molécula permanece voltada para a fase móvel polar formando assim uma superfície carregada, o analito com íon de carga oposta é então retido por atração eletrostática. ${ }^{49,50}$

A cromatografia por troca iônica (Ion Exchange chromatography - IEC) é uma técnica analítica valiosa para a separação e determinação de compostos iônicos. A separação basea-se em interações iônicas entre analitos carregados e polares, íons presentes no solvente de eluição e grupos funcionais iônicos, positivo ou negativo, presentes na FE (Figura 6). Dois mecanismos de separação estão envolvidos neste tipo de cromatografia: troca iônica devido à ligação iônica competitiva (atração), e exclusão iônica devido à repulsão entre analitos de mesma carga dos grupos funcionais carregados pertencentes a FE. ${ }^{51}$ 


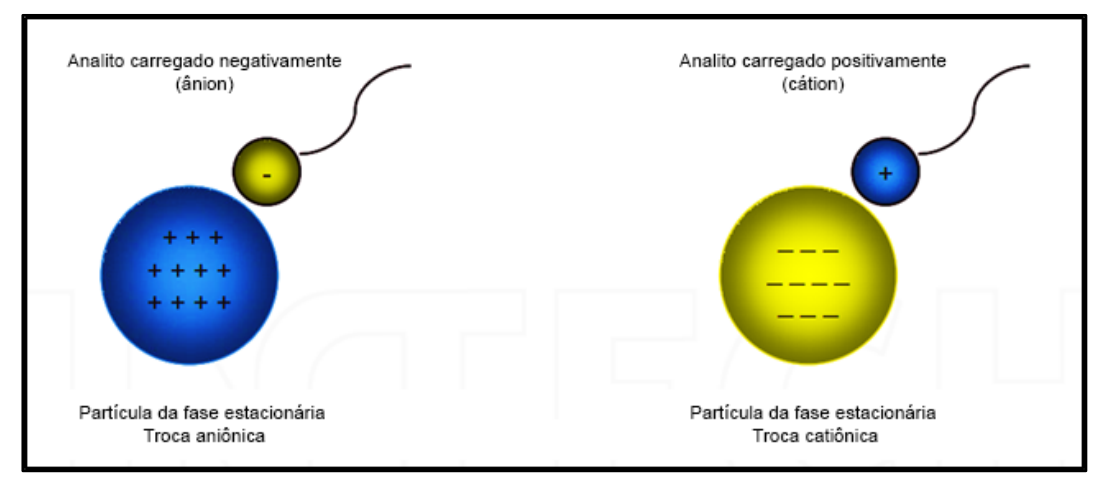

Figura 6. Tipos de cromatografia por troca iônica (IEC): catiônica e aniônica respectivamente (adaptado de Acikara). ${ }^{51}$

\subsubsection{Preparo de amostra em metabolômica}

O preparo de amostra em metabolômica é um dos fatores determinantes para a obtenção de dados representativos e reprodutíveis da via metabólica de microrganismos. A investigação do metaboloma requer uma fonte de biomassa obtida através do crescimento de microrganismos sob condições controladas de temperatura, $\mathrm{pH}$, e da concentração dos gases $\mathrm{O}_{2}$ e $\mathrm{CO}_{2}$ dissolvidos no meio de cultura. ${ }^{23} \mathrm{~A}$ amostra é coletada durante a fase de crescimento exponencial da levedura, pois nesta etapa há uma maior produção dos metabólitos intracelulares. ${ }^{23,24}$ No entanto, o tempo de rotatividade de muitos intermediários das reações metabólicas é da ordem de segundos, devido às altas taxas de conversão e baixa concentração dos metabólitos encontradas em microrganismos. ${ }^{25}$ Desta forma, a rápida interrupção da atividade celular, após a amostragem, é necessária para evitar alterações nos níves de concentração dos metabólitos intracelulares. ${ }^{23,25}$ Adicionalmente, um método de extração eficiente é essencial para a obtenção destes metabólitos. ${ }^{23}$

O método quenching tem por objetivo interromper instantaneamente as reações enzimáticas decorrentes do metabolismo celular através de mudanças bruscas de temperatura ou $\mathrm{pH}$, ou ainda submetendo a amostra a temperaturas muito baixas $\left(<-20^{\circ} \mathrm{C}\right) \cdot{ }^{27,28} \mathrm{O}$ protocolo de quenching frequentemente utilizado 
foi proposto por De koning e van Dam (1992) ${ }^{29}$ e consiste na adição da amostra em uma solução de metanol $60 \%(\mathrm{v} / \mathrm{v})$ a $-40^{\circ} \mathrm{C}$. Este procedimento pode ser encontrado nos trabalhos de Park et. al. ${ }^{24}$,Canelas et. al. ${ }^{25}$, Kim et. al. ${ }^{26}$, VillasBôas et. al. ${ }^{28}$ e Park et. al. ${ }^{30}$. A vantagem do uso da solução de metanol gelado na etapa de quenching está na separação efetiva dos metabólitos extracelulares e intracelulares, ao mesmo tempo em que o metabolismo celular é interrompido.

No entanto, Villas-Bôas et. al. (2005) ${ }^{28}$ constataram a relação do uso do metanol gelado com o processo de leakage, ou seja, a saída dos metabólitos da célula para o meio extracelular. Além disto, concluíram que a intensidade deste fenômeno é diretamente proporcional ao tempo de contato da amostra com a solução de metanol, e que alguns compostos são mais suscetíveis a este processo, por exemplo, os aminoácidos.

Carnicer et. al. $(2012)^{31}$ testaram cinco protocolos de quenching (tabela1), para a levedura Pichia pastoris, e em todos os procedimentos testados houve perdas dos metabólitos intracelulares. Os resultados encontrados foram comparados com um estudo anterior realizado por Canelas et. al. $(2008)^{25}$ com a levedura $S$. cerevisiae, a qual mostrou ser mais vulnerável ao uso da solução de quenching. Estes estudos comprovam que o protocolo de quenching deve ser otimizado para cada microorganismo, a fim de minimizar as inevitáveis perdas decorrentes deste processo.

A extração dos metabólitos pode ser alcançada através de altas temperaturas, $\mathrm{pH}$ extremo, solventes orgânicos, por ação mecânica ou pela combinação de todos esses fatores. Durante a etapa de extração as paredes celulares são quimicamente, termicamente ou mecanicamente rompidas para a passagem dos metabólitos para a fase líquida. ${ }^{27}$ Canelas et al $(2009)^{32}$ destacaram três requisitos essenciais para um método de extração eficiente: i) o método adotado deve garantir a integridade da amostra para que apenas os analitos de interesse estejam acessíveis para a análise, ii) este procedimento deve garantir que não ocorram mudanças químicas ou enzimáticas dos metabólitos durante a etapa de extração e/ou etapas posteriores, iii) não pode causar intensa degradação dos metabólitos . 
Park et. al. (2012) ${ }^{30}$, Villas-Bôas et. al. (2005) $)^{28}$ e Canelas et. al. (2009) $)^{32}$ testaram diferentes métodos de extração dos metabólitos intracelulares sendo: metanol puro (Pure Methanol - PM), etanol fervente (Boiling Ethanol - BE), Metanol/Clorofórmio (Methanol/ Chloroform - $\mathrm{CM}$ ), água quente (Hot Water $\mathrm{HW})$, hidróxido de potássio $(\mathrm{KOH})$, ácido perclórico ( Perchloric Acid - PCA), congelamento e descongelamento em metanol (Freezing-Thawing in Methanol - FTM) e acetonitrila/metanol ácidos (Acidic Acetonitrile-Methanol - AANM). Na Tabela 1 são apresentados os métodos de extração testados e aqueles que proporcionaram os melhores resultados segundo os autores. Embora não seja possível afirmar que os metabólitos foram completamente extraídos, já que a concentração inicial destes metabólitos no microrganismo é desconhecida, podem ser verificadas a ausência da atividade enzimática e a extensão da degradação desses metabólitos através de testes de recuperação, como o método de spiking ou adição de padrão. ${ }^{32}$

Tabela 1. Comparação dos procedimentos de extração dos metabólitos intracelulares em microrganismos classificados em ótimo $=x x x$, bom $=x x$ e pouco eficiente $=x$.

\begin{tabular}{|c|c|c|c|c|c|c|c|c|c|c|}
\hline $\begin{array}{c}\text { Métodos de } \\
\text { extração/Autores }\end{array}$ & PM & $\mathrm{BE}$ & $\mathrm{CM}$ & HW & MW & PCA & $\mathrm{KOH}$ & FTM & AANM & Microrganismo \\
\hline Park et $\left.a\right|^{30}$ & $x \mathrm{xx}$ & $x x$ & $x x x$ & $x x x$ & & $x x$ & $x$ & & & $\begin{array}{c}\text { Klebsiella } \\
\text { oxytoca }\end{array}$ \\
\hline Villas-Bôas et $a^{28}$ & $\mathrm{xxx}$ & $x x$ & $x x$ & & $\mathrm{xxx}$ & $x$ & $x$ & & & S. cerevisiae \\
\hline Canelas et $a \beta^{32}$ & & $\mathrm{xxx}$ & $x x x$ & $x x$ & & & & $\mathrm{x}$ & $\bar{x}$ & S. cerevisiae \\
\hline
\end{tabular}

O preparo de amostra em metabolômica envolve dois procedimentos principais: o quenching e a extração. Na Figura 7 é apresentado o fluxo de trabalho envolvendo estas duas etapas. Após a otimização destes protocolos, os metabólitos extraídos são recuperados e podem ser analisados por diferentes métodos analíticos. 


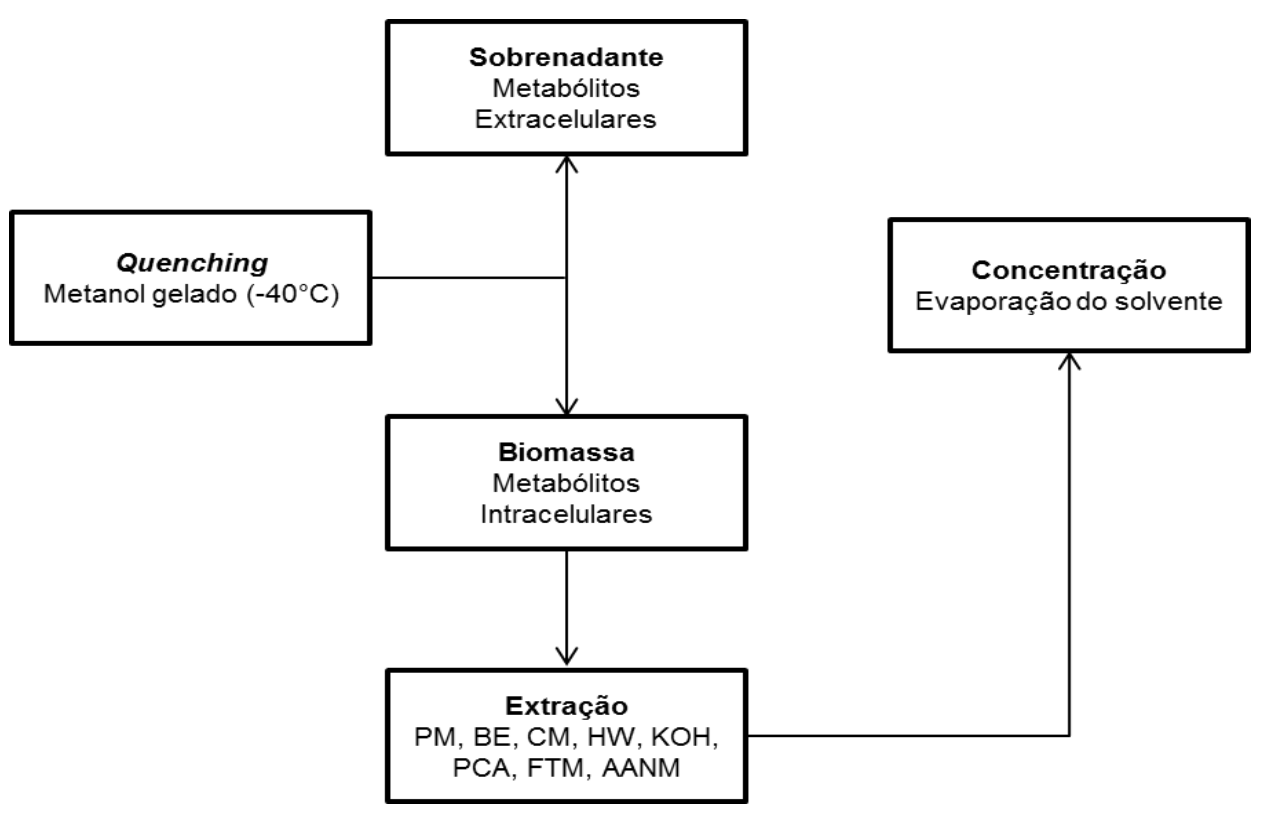

Figura 7. Fluxo de trabalho do preparo de amostra aplicado em metabolômica (adaptado de Villas-Bôas et al, 2005). ${ }^{28}$

\subsubsection{Metabolismo de xilose em leveduras}

Espécies de leveduras, tais como Scheffersomyces stipitis (previamente conhecida como Pichia stipitis), Candida shehatae, C. tenuis, Debaryomyces hansenii, Spathaspora passalidarum e Pachisolen tannophilus, naturalmente consomem e fermentam xilose, e diversos estudos têm sido realizados para melhorar a compreensão do metabolismo de pentoses nestas espécies (Wohlbach et. al., 2011) ${ }^{52}$. Por outro lado, a construção e o melhoramento de linhagens recombinantes de $S$. cerevisiae deve facilitar o desenvolvimento de processos industriais de etanol lignocelulósico, já que linhagens não modificadas geneticamente dessa levedura são responsáveis por praticamente toda a produção mundial de etanol (Basso et. al., 2008) ${ }^{53}$. Linhagens recombinantes de $S$. cerevisiae capazes de fermentar xilose são construídas pela expressão das enzimas XR (xilose redutase) e XDH (xilitol desidrogenase, via oxido-redutiva) ou XI (via da xilose isomerase). Estas enzimas são responsáveis pela conversão de xilose a xilulose, um metabólito que a levedura é capaz de converter a etanol (Almeida et. al., 2011) ${ }^{54}$. Linhagens construídas pela simples expressão desses genes são capazes de produzir etanol, 
entretanto, com baixo rendimento. Assim, independente da via utilizada, outras modificações se mostraram necessárias para aumentar a produtividade do processo (Karhumaa et. al., 200555; Kuyper et. al., 200556; Runquist et. al.,

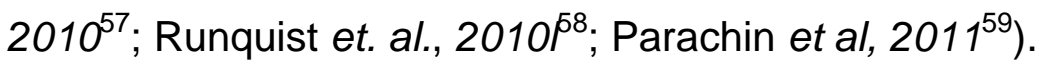

Apesar de várias abordagens terem sido utilizadas, com variável taxa de sucesso, o uso de uma abordagem que inclua a coleta, análise e integração quantitativa de dados biológicos em larga escala através de ferramentas ômicas (genômica, transcriptômica, metabolômica), pode resultar na construção de modelos biologicamente mais relevantes e preditivos para melhorar a capacidade fermentativa de $S$. cerevisiae ${ }^{60}$.

A abordagem da metabolômica pode ser usada para traçar novas estratégias para o desenvolvimento de microrganismos mais eficientes e modificados através da engenharia genética. No entanto, para a realização da análise metabolômica de leveduras é necessário o desenvolvimento e otimização dos protocolos analíticos envolvidos em cada etapa do processo, desde o preparo até a análise das amostras. Métodos analíticos devem ser desenvolvidos para a identificação e quantificação dos metabólitos presentes na via de fermentação da xilose (Figura 8). 


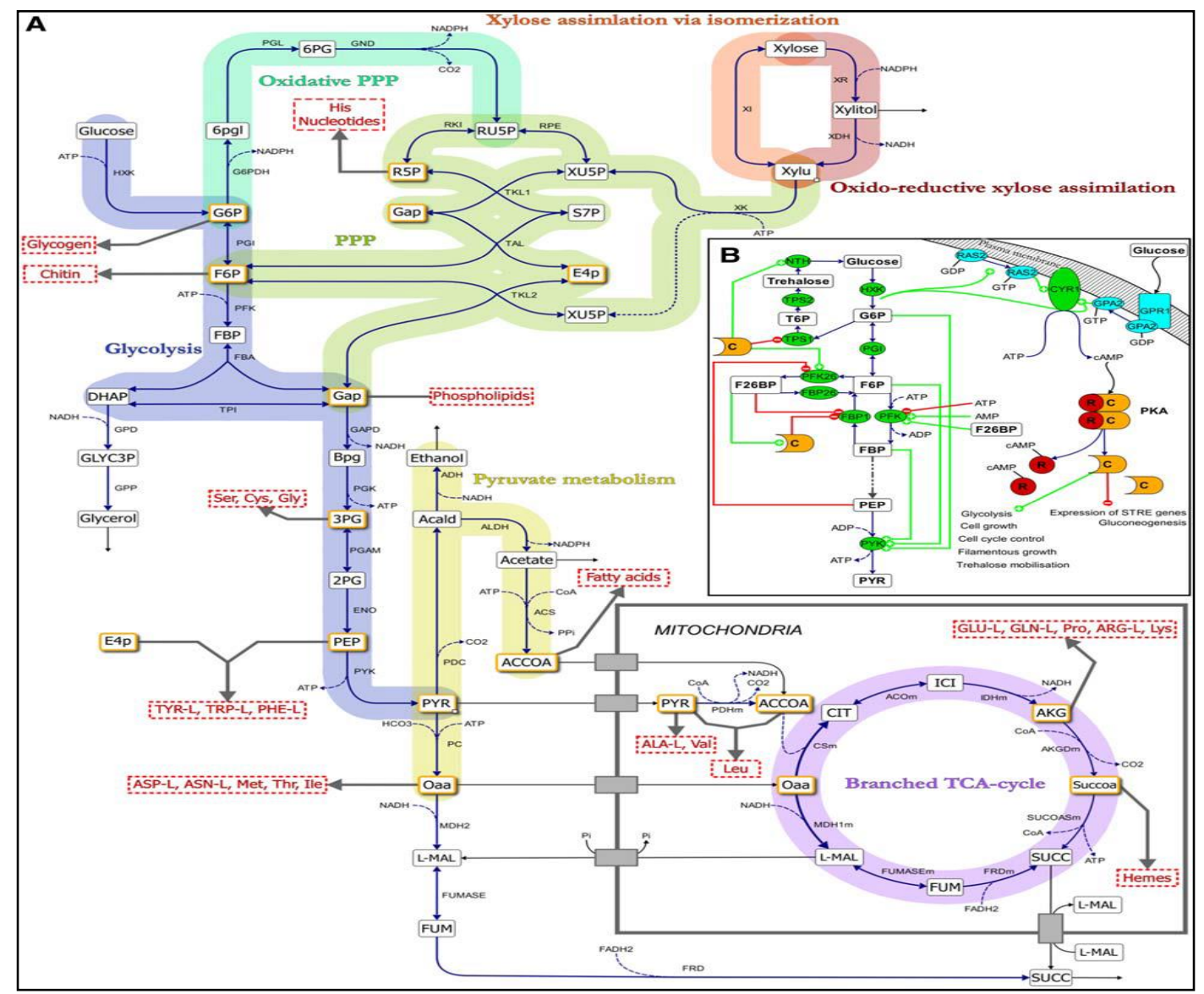

Figura 8. Visão geral das principais reações metabólicas no metabolismo do carbono central (adaptado de Bergdahl et al, 2012). ${ }^{61}$

Desta forma, o presente trabalho buscou desenvolver protocolos analíticos em metabolômica para a identificação de metabólitos presentes na via de fermentação da xilose por leveduras. Métodos de quenching e extração dos metabólitos de leveduras foram realizados e os metabólitos extraídos foram analisados por métodos desenvolvidos utilizando a cromatografia líquida de ultra-alta eficiência (UHPLC), com avaliação de três modos de separação, seguidos por detecção por espectrometria de massas tandem (MS/MS). 
OBJETIVOS 


\section{Objetivos}

O objetivo principal do presente trabalho foi desenvolver e otimizar um protocolo de análise de metabólitos produzidos na via de fermentação de xilose por leveduras.

\subsection{Objetivos Específicos}

Os objetivos específicos deste trabalho foram:

- Otimizar as etapas de preparo de amostra e extração de metabólitos;

- Desenvolver métodos analíticos baseados em cromatografia líquida e espectrometria de massas para identificação dos metabólitos;

- Aplicar o protocolo de análises desenvolvido e otimizado em amostras reais contendo xilose convertida por leveduras. 
MATERIAIS

\author{
E \\ MÉTODOS
}




\section{MATERIAIS E MÉTODOS}

\subsection{Reagentes e Soluções}

Os padrões de metabólitos utilizados foram adquiridos da SigmaAldrich com pureza $\geq 95 \%$. O nome, a sigla e a fórmula molecular destes padrões estão listados abaixo:

- Acetil Co-enzima A sal de lítio, (ACCOA), $\mathrm{C}_{23} \mathrm{H}_{38} \mathrm{~N}_{7} \mathrm{O}_{17} \mathrm{P}_{3} \mathrm{~S} \cdot \mathrm{xLi}^{+}$;

- Acetaldeído, (Acald), $\mathrm{C}_{2} \mathrm{H}_{4} \mathrm{O}$

- Ácido Alfacetoglutárico, (AKG), $\mathrm{C}_{5} \mathrm{H}_{6} \mathrm{O}_{5}$;

- Ácido D-Málico, (L-MAL), $\mathrm{C}_{4} \mathrm{H}_{6} \mathrm{O}_{5}$;

- Ácido Oxaloacético, (Oaa) , $\mathrm{C}_{4} \mathrm{H}_{4} \mathrm{O}_{5}$;

- D-(+)-Glicose, $\mathrm{C}_{6} \mathrm{H}_{12} \mathrm{O}_{6}$;

- D-(+)-Xilose, $\mathrm{C}_{5} \mathrm{H}_{10} \mathrm{O}_{5}$;

- D-Glicose-6-Fosfato (solução), (G6P), $\mathrm{C}_{6} \mathrm{H}_{13} \mathrm{O}_{9} \mathrm{P}$;

- D-Frutose-6-Fosfato sal de disódico hidratado, (F6P), $\mathrm{C}_{6} \mathrm{H}_{11} \mathrm{Na}_{2} \mathrm{O}_{9} \mathrm{P} \cdot \mathrm{xH}_{2} \mathrm{O}$;

- Di-hidroxiacetona Fosfato Hemimagnésio sal hidratado, (DHAP), $\mathrm{C}_{3} \mathrm{H}_{5} \mathrm{MgO}_{6} \mathrm{P} \cdot \mathrm{xH}_{2} \mathrm{O}$;

- DL-Gliceraldeído-3-Fosfato, (GAP), $\mathrm{C}_{3} \mathrm{H}_{7} \mathrm{O}_{6} \mathrm{P}$;

- D-Ribose-5-Fosfato sal disódico dihidratado, (R5P), $\mathrm{C}_{5} \mathrm{H}_{9} \mathrm{Na}_{2} \mathrm{O}_{8} \mathrm{P} \cdot 2 \mathrm{H}_{2} \mathrm{O}$;

- D-Ribulose-5-Fosfato sal disódico, (RU5P), $\mathrm{C}_{5} \mathrm{H}_{9} \mathrm{Na}_{2} \mathrm{O}_{8} \mathrm{P}$;

- D-Xilulose, (Xylu), $\mathrm{C}_{5} \mathrm{H}_{10} \mathrm{O}_{5}$;

- Ácido Fosfo(enol)pirúvico sal monopotássico, (PEP), $\mathrm{C}_{3} \mathrm{H}_{4} \mathrm{KO}_{6} \mathrm{P}$;

- Glicerol, $\mathrm{C}_{3} \mathrm{H}_{8} \mathrm{O}_{3}$;

- Piruvato de Sódio, (PYR), $\mathrm{C}_{3} \mathrm{H}_{3} \mathrm{NaO}_{3}$;

- Xilitol, $\mathrm{C}_{5} \mathrm{H}_{12} \mathrm{O}_{5}$. 
Os solventes e reagentes utilizados no preparo de soluções para a realização dos experimentos encontram-se listados abaixo:

- Ácido Fórmico, $\mathrm{CO}_{2} \mathrm{H}_{2}$, pureza $\geq 95 \%$, Sigma-Aldrich;

- Ácido Trifluoro Acético, $\mathrm{CF}_{3} \mathrm{COOH}$, pureza $\geq 99 \%$, Sigma-Aldrich;

- Acetato de amônio, $\mathrm{CH}_{3} \mathrm{COONH}_{4}, 98 \%$ p.a., Vetec;

- Acetonitrila, $\mathrm{CH}_{3} \mathrm{CN}$, pureza $\geq 99 \%$, Sigma-Aldrich;

- Formiato de amônio, $\mathrm{HCO}_{2} \mathrm{NH}_{4}$, pureza $\geq 99 \%$, Sigma-Aldrich;

- Solução de Hidróxido de Amônio, $\geq 25 \%$ em Água, $\mathrm{NH}_{4} \mathrm{OH}$, aditivo eluente para LC-MS, Fluka;

- Tributilamina, $\mathrm{C}_{12} \mathrm{H}_{27} \mathrm{~N}$, pureza $\geq 99,5 \%, \mathrm{GC}$, Sigma-Aldrich;

- Trietilamina, pureza $\geq 99,5 \%, G C$, Sigma-Aldrich;

- Água ultrapura obtida em sistema Milli-Q Direct 16 Millipore (resisitividade $18,2 \mathrm{M} \Omega . \mathrm{cm})$;

- Metanol, $\mathrm{CH}_{4} \mathrm{O}$, pureza $\geq 99,5 \% \%$, GC, Sigma-Aldrich;

- Mono Etilenoglicol, $\mathrm{C}_{2} \mathrm{H}_{6} \mathrm{O}_{2}$, p.a., Vetec.

Os padrões de metabólitos foram pesados em balança analítica ( $A B$ 265-S/FACT, Mettler Toledo) e diluídos em 3,0 mL de água ultra pura (Milli-Q), com exceção dos compostos: GAP, G6P, Xylu e glicerol que foram adquiridos em solução. A concentração da maior parte das soluções foi de $1 \mathrm{mg} / \mathrm{mL}$, no entanto, o padrão RU5P não possuía quantidade suficiente para atingir a concentração utilizada. Os volumes pipetados e as concentrações em $\mathrm{mg} / \mathrm{mL}$ e $\mathrm{mol} / \mathrm{L}$, destes padrões, encontram-se na Tabela 2. As soluções preparadas foram armazenadas a $-20^{\circ} \mathrm{C}$ em vials de $8 \mathrm{~mL}$ para posterior diluição e análise. 
Tabela 2. Dados do preparo das soluções estoque dos padrões de metabólitos analisados.

\begin{tabular}{|c|c|c|c|}
\hline Composto & $\begin{array}{c}\text { Massa Pesada } \\
(\mathrm{mg})\end{array}$ & $\begin{array}{c}\text { Concentração } \\
(\mathrm{mg} / \mathrm{mL})\end{array}$ & $\begin{array}{c}\text { Concentração } \\
(\mathrm{mmol} / \mathrm{L})\end{array}$ \\
\hline ACCOA & 3,19 & 1,0633 & 1,31 \\
\hline AKG & 3,10 & 1,0333 & 4,57 \\
\hline L-MAL & 3,18 & 1,0600 & 7,91 \\
\hline Oaa & 3,53 & 1,1767 & 8,85 \\
\hline DHAP & 3,60 & 1,2000 & 1,71 \\
\hline F6P & 3,32 & 1,1067 & 3,64 \\
\hline PEP & 3,26 & 1,0867 & 5,28 \\
\hline G6P & 15,4 & 1,0010 & 3,85 \\
\hline Glicerol $^{\mathrm{a}}$ & 551,7 & 0,9995 & 10,86 \\
\hline GAP & 63,0 & 1,0080 & 5,93 \\
\hline D-Glicose & 3,71 & 1,2367 & 6,87 \\
\hline PYR & 3,97 & 1,3233 & 12,03 \\
\hline R5P & 3,65 & 1,2167 & 3,94 \\
\hline RU5P & 1,97 & 0,6567 & 2,12 \\
\hline Xilose & 3,46 & 1,1533 & 7,69 \\
\hline Xilitol & 3,06 & 1,0200 & 6,71 \\
\hline Xylu ${ }^{a}$ & 303,0 & 1,0011 & 6,67 \\
\hline${ }^{a}$ Volume em $(\mu L)$ & \multicolumn{3}{|l}{} \\
\hline \multicolumn{3}{|l}{}
\end{tabular}

\subsection{Desenvolvimento de métodos analíticos}

\subsubsection{Espectrometria de Massas (MS- Mass Spectrometry)}

A técnica de infusão direta por espectrometria de massas (DIMS - Direct Infusion Mass Spectrometry) foi utilizada para otimizar as condições de análises por MRM (Multiple Reaction Monitoring) para cada padrão de metabólito. Inicialmente foram calculados os valores teóricos das massas (protonada $[\mathrm{M}+\mathrm{H}]^{+}$, desprotonada $[\mathrm{M}-\mathrm{H}]^{-}$e sodiada $[\mathrm{M}+\mathrm{Na}]^{+}$) de cada metabólito de interesse para o experimento de full scan (MS), estes dados estão apresentados na Tabela 3. 
Tabela 3. Valor teórico das massas dos padrões de metabólitos de interesse.

\begin{tabular}{|c|c|c|c|c|}
\hline Composto & Massa Molar & {$\left[\mathrm{M}+\mathrm{H}^{+}\right.$} & {$[\mathrm{M}-\mathrm{H}]$} & ${ }^{+}$ \\
\hline ACCOA & 809,1258 & 810,1 & 808,1 & 833,1 \\
\hline AKG & 226,0065 & 227,0 & 225,0 & 249,0 \\
\hline L-MAL & 134,0215 & 135,0 & 133,0 & 157,0 \\
\hline Oaa & 133,0137 & 134,0 & 132,0 & 156,0 \\
\hline Acald & 44,0262 & 45,0 & 43,0 & 67,0 \\
\hline DHAP & 701,7008 & 702,7 & 700,7 & 724,7 \\
\hline F6P & 303,9936 & 305,0 & 303,0 & 327,0 \\
\hline PEP & 205,9383 & 206,9 & 205,0 & 229,0 \\
\hline G6P & 260,0297 & 261,0 & 259,0 & 283,0 \\
\hline Glicerol & 92,0473 & 93,0 & 91,0 & 115,0 \\
\hline GAP & 169,9980 & 171,0 & 169,0 & 193,0 \\
\hline D-Glicose & 180,0634 & 181,1 & 179,0 & 203,0 \\
\hline PYR & 109,9980 & 111,0 & 109,0 & 133,0 \\
\hline R5P & 308,9963 & 310,0 & 308,0 & 332,0 \\
\hline RU5P & 310,0042 & 311,0 & 309,0 & 333,0 \\
\hline Xilose & 150,0528 & 151,1 & 149,0 & 173,0 \\
\hline Xilitol & 152,0685 & 153,1 & 151,0 & 175,0 \\
\hline Xylu & 150,0530 & 151,1 & 149,0 & 173,0 \\
\hline
\end{tabular}

Em seguida, as soluções dos padrões individuais e em uma mistura foram infundidos no espectrômetro de massas com fonte de ionização por electrospray (ESI) nos modos: negativo (ESI-(-)-MS) e positivo (ESI-(+)-MS), e analisador do tipo triplo quadrupolo (QqQ) (TQD, Waters). As análises foram realizadas infundindo os padrões com solução aquosa contendo $0,1 \%$ de ácido fórmico para a análise de MS em modo positivo (ESI(+)-MS) e $0,1 \%$ de hidróxido de amônio para análise de MS em modo negativo (ESI(-)-MS), e uma fase orgânica composta por $5 \%$ de acetonitrila (ACN).

Os parâmetros instrumentais do espectrômetro de massas utilizados estão descritos a seguir: vazão da amostra: $0,4 \mathrm{~mL} / \mathrm{min}$, voltagem do capilar: + $3500 \mathrm{~V}$, temperatura de solvatação: $450^{\circ} \mathrm{C}$, temperatura da fonte: $130^{\circ}$, fluxo do gás do cone: $20 \mathrm{~L} / \mathrm{h}$ e fluxo do gás de solvatação: $700 \mathrm{~L} / \mathrm{h}$.

A mistura de padrões e os compostos individuais injetados foram preparados a partir das soluções estoque contidos na tabela 3. Foram pipetados $100 \mu \mathrm{L}$ de cada padrão para um balão volumétrico de $10 \mathrm{~mL}$, cujo volume foi completado com água ultra pura, obtendo-se uma concentração final 
de $10 \mu \mathrm{g} / \mathrm{mL}$ de uma mistura contendo 18 padrões de metabólitos. Os padrões individuais foram diluídos nas concentrações 10, 25, 50 e $100 \mu \mathrm{g} / \mathrm{mL}$. As Tabelas 4 e 5 indicam os valores das concentrações em $\mu \mathrm{M}$ dos padrões na mistura e dos compostos analisados individualmente, respectivamente.

Tabela 4. Concentração dos padrões de metabólitos diluídos para o preparo da mistura de $10 \mu \mathrm{g} \cdot \mathrm{mL}^{-1}$.

\begin{tabular}{|c|c|}
\hline Composto & $\begin{array}{c}\text { Concentração } \\
(\boldsymbol{\mu M})\end{array}$ \\
\hline ACCOA & 13,14 \\
\hline AKG & 45,72 \\
\hline L-MAL & 79,09 \\
\hline Oaa & 88,46 \\
\hline Acald & 23,89 \\
\hline DHAP & 17,10 \\
\hline F6P & 36,40 \\
\hline PEP & 52,77 \\
\hline G6P & 51,33 \\
\hline Glicerol & 787,28 \\
\hline GAP & 59,29 \\
\hline D-Glicose & 68,68 \\
\hline PYR & 120,31 \\
\hline R5P & 39,37 \\
\hline RU5P & 21,18 \\
\hline Xilose & 76,86 \\
\hline Xilitol & 67,08 \\
\hline Xylu & 66,72 \\
\hline
\end{tabular}


Tabela 5. Concentração dos padrões de metabólitos diluídos individualmente.

\begin{tabular}{|c|c|c|}
\hline Composto & $\begin{array}{c}\text { Concentração } \\
(\boldsymbol{\mu g} / \mathbf{m L})\end{array}$ & $\begin{array}{c}\text { Concentração } \\
(\boldsymbol{\mu M})\end{array}$ \\
\hline ACCOA & 25,0 & 32,85 \\
\hline AKG & 25,0 & 114,30 \\
\hline L-MAL & 10,0 & 79,09 \\
\hline Oaa & 10,0 & 88,46 \\
\hline Acald & 25,0 & 59,73 \\
\hline DHAP & 10,0 & 17,10 \\
\hline F6P & 25,0 & 91,01 \\
\hline PEP & 25,0 & 131,92 \\
\hline G6P & 10,0 & 51,33 \\
\hline Glicerol & 10,0 & 787,28 \\
\hline GAP & 25,0 & 148,24 \\
\hline D-Glicose & 10,0 & 68,68 \\
\hline PYR & 10,0 & 120,31 \\
\hline R5P & 100,0 & 393,75 \\
\hline RU5P & 25,0 & 52,96 \\
\hline Xilose & 50,0 & 384,31 \\
\hline Xilitol & 50,0 & 335,38 \\
\hline Xylu & 10,0 & 66,72 \\
\hline & & \\
\hline
\end{tabular}

Os parâmetros de cone e capilar foram otimizados para cada metabólito a fim de obter íons mais intensos, e consequentemente, a melhor sensibilidade de detecção possível para cada metabólito.

Após a identificação do íon precursor mais intenso referente ao metabólito de interesse, este íon foi submetido ao experimento de espectrometria de massas tandem (MS/MS). Os valores da energia de colisão foram otimizados empiricamente para garantir o fragmento mais intenso e/ou seletivo para cada padrão. Os dados obtidos nesta etapa foram utilizados para configurar os canais do método MRM. 


\subsubsection{Cromatografia líquida de ultra alta eficiência acoplada a espectrometria de massas (UHPLC-MS)}

A separação dos metabólitos foi realizada utilizando a cromatografia líquida de ultra alta eficiência, acoplada a espectrometria de massas (UHPLCMS)(Acquity Xevo TQD, Waters). Foram testadas três diferentes colunas cromatográficas: BEH-amida (Waters), HSS-T3 (Waters) e Aminex (Bio-Rad).

$O$ desenvolvimento do método cromatográfico abordou os seguintes parâmetros: diferentes solventes e vazão de fase móvel, modos de eluição (isocrático e gradiente), utilizando um sistema de solvente binário constituído por uma fase $A$, com solvente aquoso e uma fase $B$ com solvente orgânico e estudos de influência da temperatura e do $\mathrm{pH}$.

\subsubsection{Cromatografia de interação hidrofílica (HILIC- Hydrophilic interaction liquid chromatography)}

A coluna BEH amida com dimensões 2,1 x $150 \mathrm{~mm} \times 1,7 \mu \mathrm{m}$ (Waters) foi utilizada para o desenvolvimento do método (HILIC). Foram testados diferentes composições de fase móvel, em modo gradiente e isocrático. As temperaturas do forno de coluna avaliadas variaram de $35^{\circ} \mathrm{C}$ a $60^{\circ} \mathrm{C}$, e para alguns experimentos foram testados a influência da variação dos valores de $\mathrm{pH}$ (Tabela 6).

O gradiente que obteve melhor separação dos picos cromatográficos para a fase móvel, composta pelos solventes A: Hidróxido de amônio 0,1\% e B: Hidróxido de amônio 0,1\% em acetonitrila, está descrito na Tabela 7, a temperatura do forno de coluna utilizado foi $50^{\circ} \mathrm{C}$. 
Tabela 6. Condições cromatográficas testadas para o desenvolvimento do método HILIC utilizando a coluna BEH amida.

\begin{tabular}{|c|c|c|c|}
\hline Condições & Fase móvel & Sistema & $\mathrm{pH}$ \\
\hline 1 & $\begin{array}{l}\text { Formiato de Amônio } 10 \mathrm{mM}+ \\
75 \% \mathrm{ACN}\end{array}$ & Isocrático & $\begin{array}{c}7,22 / 6,04 / \\
4,5\end{array}$ \\
\hline 2 & $\begin{array}{c}\text { A: Acetonitrila + Formiato de } \\
\text { Amônio } 0,1 \% \text { (aquoso) }(20 / 80) \\
\text { B: Acetonitrila + Formiato de } \\
\text { Amônio } 0,1 \% \text { (aquoso) }(80 / 20)\end{array}$ & Gradiente & - \\
\hline 3 & $\begin{array}{c}\text { Acetato de Amônio } 5 \mathrm{mM}+ \\
\text { Acetonitrila/ } \mathrm{H}_{2} \mathrm{O}(75 / 25)+\mathrm{NH}_{4} \mathrm{OH} \\
0,1 \%\end{array}$ & Isocrático & 9,38 \\
\hline 4 & $\begin{array}{l}\text { A: Formiato de Amônio } 5 \mathrm{mM} \\
\text { (aquoso) + Acetonitrila (10/90) } \\
\text { B: Formiato de Amônio } 5 \mathrm{mM} \\
\text { (aquoso) + Acetonitrila (50/50) }\end{array}$ & Gradiente & - \\
\hline 5 & $\begin{array}{l}\text { A: Formiato de Amônio } 5 \mathrm{mM} \\
\text { (aquoso) + Acetonitrila }(90 / 10) \\
\text { B: Formiato de Amônio } 5 \mathrm{mM} \\
\text { (aquoso) + Acetonitrila }(10 / 90)\end{array}$ & Gradiente & - \\
\hline 6 & $\begin{array}{l}\text { A: Acetato de Amônio } 10 \mathrm{mM} \\
\text { (aquoso) + Acetonitrila }(50 / 50) \\
\text { B: Acetato de Amônio } 10 \mathrm{mM} \\
\text { (aquoso) + Acetonitrila }(90 / 10)\end{array}$ & Gradiente & - \\
\hline 7 & $\begin{array}{l}\text { A: Acetato de Amônio } 15 \mathrm{mM} \\
\text { (aquoso) + Acetonitrila }(50 / 50) \\
\text { B: Acetato de Amônio } 15 \mathrm{mM} \\
\text { (aquoso) + Acetonitrila }(80 / 20)\end{array}$ & Gradiente & - \\
\hline 8 & $\begin{array}{l}\text { A: Hidróxido de Amônio 0,05\% } \\
\text { (aquoso) + Acetonitrila }(90 / 10) \\
\text { B: Hidróxido de Amônio 0,05\% } \\
\text { (aquoso) + Acetonitrila }(50 / 50)\end{array}$ & Gradiente & - \\
\hline 9 & $\begin{array}{c}\text { A: Hidróxido de Amônio } 0,1 \% \\
\text { B: Acetonitrila + Hidróxido de } \\
\text { Amônio } 0,1 \%\end{array}$ & Gradiente & - \\
\hline
\end{tabular}


Tabela 7. Gradiente aplicado no método HILIC otimizado.

\begin{tabular}{|c|c|c|c|c|}
\hline Etapas & $\begin{array}{c}\text { Tempo } \\
(\mathbf{m i n})\end{array}$ & $\begin{array}{c}\text { Fluxo } \\
(\mathbf{m L} / \mathbf{m i n})\end{array}$ & $\begin{array}{c}\text { Eluente A } \\
(\text { vol \%) }\end{array}$ & $\begin{array}{c}\text { Eluente B } \\
(\text { vol \%) }\end{array}$ \\
\hline 1 & Início & 0,2 & 15 & 85 \\
\hline 2 & 6.5 & 0,2 & 50 & 50 \\
\hline 3 & 7.5 & 0,4 & 50 & 50 \\
\hline 4 & 8.0 & 0,2 & 15 & 85 \\
\hline 5 & 12.0 & 0,2 & 15 & 85 \\
\hline
\end{tabular}

\subsubsection{Cromatografia por pareamento iônico (IPC - Ion-pair chromatography)}

Uma coluna de fase reversa com dimensões $2,1 \times 150 \mathrm{~mm} \times 1,8 \mu \mathrm{m}$ HSS-T3 (Waters), do tipo C18 com grupo polar embutido, foi utilizada para o desenvolvimento do método IPC conforme descrito por Buescher et $\mathrm{al}^{51}$ e Luo et $a^{5^{2}}$. Todos os experimentos foram realizados em modo gradiente, sendo a fase móvel A constituída por reagentes do pareamento iônico e para a fase móvel $\mathrm{B}$ o solvente utilizado foi o metanol.

Os reagentes do pareamento iônico testados foram a trietilamina e a tributilamina. Foram testados diferentes composições de fase móvel e valores de $\mathrm{pH}$, e temperaturas do forno de coluna (Tabela 8). 
Tabela 8. Condições cromatográficas testadas para o desenvolvimento do método IPC utilizando a coluna HSS-T3.

\begin{tabular}{|c|c|c|c|}
\hline Condições & Coluna HSS-T3 & $\begin{array}{l}\text { Temperatura } \\
\left({ }^{\circ} \mathrm{C}\right)\end{array}$ & $\mathrm{pH}$ \\
\hline 1 & $\begin{array}{c}\text { A: Trietilamina } 5 \mathrm{mM}+\text { Ácido Fórmico } 10 \\
\mathrm{mM}\end{array}$ & 35 & 3,71 \\
\hline 2 & $\begin{array}{c}\text { A: Trietilamina } 10 \mathrm{mM} \text { + Ácido Fórmico } 20 \\
\mathrm{mM}\end{array}$ & 35 & - \\
\hline 3 & $\begin{array}{l}\text { A: Tributilamina } 2 \mathrm{mM}+\text { Acetato de } \\
\text { Amônio } 5 \mathrm{mM}+5 \% \mathrm{MeOH}\end{array}$ & 45 & 6,2 \\
\hline 4 & $\begin{array}{c}\text { A: Tributilamina } 2 \mathrm{mM}+\text { Ácido Acético } 3 \\
\mathrm{mM}+5 \% \mathrm{MeOH}\end{array}$ & 45 & 5,12 \\
\hline 5 & $\begin{array}{c}\text { A: Tributilamina } 2 \mathrm{mM}+\text { Ácido Acético } 4 \\
\mathrm{mM}+5 \% \mathrm{MeOH}\end{array}$ & 45 & 4,83 \\
\hline 6 & $\begin{array}{c}\text { A: Tributilamina } 5 \mathrm{mM}+\text { Ácido Acético } 10 \\
\mathrm{mM}+5 \% \mathrm{MeOH}\end{array}$ & 45 & 4,81 \\
\hline 7 & $\begin{array}{c}\text { A: Tributilamina } 10 \mathrm{mM} \text { + Ácido Acético } \\
15 \mathrm{mM}\end{array}$ & $35 / 50$ & 5,05 \\
\hline
\end{tabular}

O gradiente que obteve melhor resolução dos picos cromatográficos para a fase móvel composta pelos solventes A: tributilamina $5 \mathrm{mM}+$ Ácido Acético $10 \mathrm{mM}+5 \%$ de $\mathrm{MeOH}$ e B: metanol, estão apresentados na Tabela 9 .

Tabela 9. Gradiente aplicado no desenvolvimento do método IPC.

\begin{tabular}{|c|c|c|c|c|}
\hline Etapas & $\begin{array}{c}\text { Tempo } \\
\text { (min) }\end{array}$ & $\begin{array}{c}\text { Fluxo } \\
(\mathbf{m L} / \mathbf{m i n})\end{array}$ & $\begin{array}{c}\text { Eluente A } \\
\text { (vol \%) }\end{array}$ & $\begin{array}{c}\text { Eluente B } \\
\text { (vol \%) }\end{array}$ \\
\hline 1 & Início & 0,4 & 100 & 0 \\
\hline 2 & 10,00 & 0,4 & 89,5 & 10,5 \\
\hline 3 & 18,00 & 0,4 & 47,4 & 52,6 \\
\hline 4 & 19,00 & 0,4 & 47,4 & 52,6 \\
\hline 5 & 20,00 & 0,4 & 100 & 0 \\
\hline 6 & 25,50 & 0,6 & 100 & 0 \\
\hline 7 & 26,00 & 0,4 & 100 & 0 \\
\hline
\end{tabular}




\subsubsection{Cromatografia por troca iônica (IEC - lon Exchange chromatography)}

Uma coluna Aminex HPX-87H de dimensões 300 x 7,8 mm x 9um (BioRad) foi utilizada para o desenvolvimento do método cromatográfico por troca iônica.

Foram testadas três diferentes FM: ácido trifluoro acético 0,05\% e 0,1\% e ácido fórmico $0,1 \%$, o reagente orgânico usado como modificador foi acetonitrila. A Tabela 10 apresenta as condições cromatográficas testadas para o desenvolvimento da cromatografia IEC, em modo isocrático.

Tabela 10. Condições cromatográficas testadas para o desenvolvimento do método IEC utilizando a coluna Aminex.

\begin{tabular}{|c|c|c|c|}
\hline Condições & Coluna Aminex & $\begin{array}{c}\text { Eluente A } \\
(\text { vol. \%) }\end{array}$ & $\begin{array}{c}\text { Fluxo } \\
(\mathbf{m l} / \mathbf{m i n})\end{array}$ \\
\hline 1 & A: Água + Ácido Fórmico 0,1\% \\
B: Acetonitrila & 100 & 0,6 \\
\hline 2 & $\begin{array}{c}\text { A: Água + TFA 0.05\% } \\
\text { B: Acetonitrila }\end{array}$ & 100 & 0,6 \\
\hline 3 & $\begin{array}{c}\text { A: Água + TFA 0,1\% } \\
\text { B: Acetonitrila }\end{array}$ & 90 & 0,5 \\
\hline
\end{tabular}

\subsection{Preparo das amostras de leveduras}

\subsubsection{Cultivo de leveduras}

O processo de fermentação das leveduras foi realizado no Laboratório de Genética e Biotecnologia (LGB), na unidade da Embrapa Agroenergia. Neste trabalho foram avaliadas duas leveduras: Scheffersomyces stipitis e Spathaspora passalidarum. As condições controladas no fermentador para 0 crescimento celular foram: $28^{\circ} \mathrm{C}$, agitação de $200 \mathrm{rpm}$, fluxo de ar de 0,05-0,1 v/L, $\mathrm{pH} 5,5$ e $_{2}$ inicial com 100\%, sendo consumido no decorrer do tempo de cultivo, até ficar em condição microaeróbica. As amostras para a determinação 
da concentração dos metabólitos intracelulares foram coletadas em três pontos específicos na fase exponencial de crescimento, entre 20 e 40 horas de fermentação microaeróbica (Figura 9).

\section{Scheffersomyces stipitis}

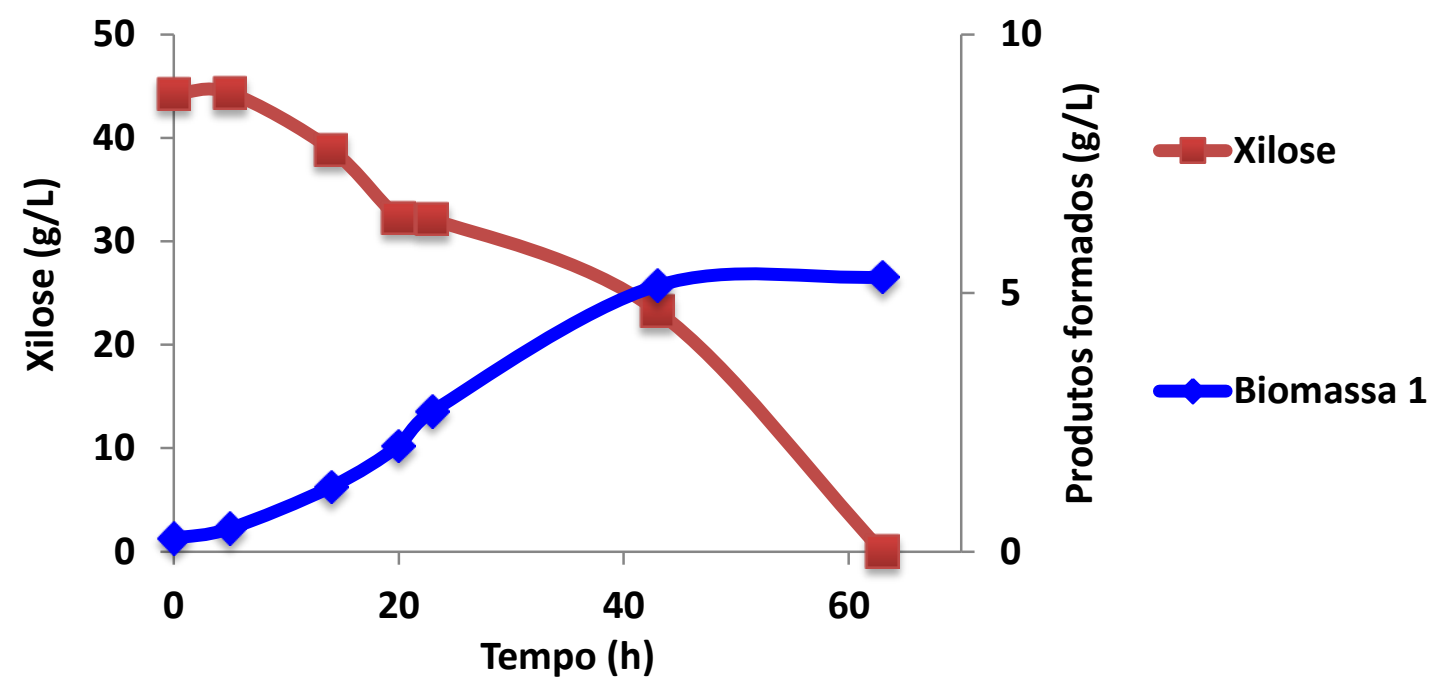

Figura 9. Gráfico de fermentação microaeróbica da levedura Scheffersomyces stipitis.

\subsubsection{Etapas de quenching e extração dos metabólitos}

O preparo de amostra biológica para a análise dos metabólitos intracelulares envolveram duas etapas: a interrupção do metabolismo celular, denominado Quenching e a extração dos metabólitos das células.

A etapa de Quenching seguiu o protocolo adaptado da metodologia de Basti et $a^{\rho^{3}}$ e adaptada. Inicialmente preparou-se uma solução tampão de metanol $(60 \%$ metanol, $10 \mathrm{mM}$ acetato de amônio, $\mathrm{pH} 7,4)$, para a adição da cultura celular. Esta solução foi distribuída em tubos falcon de $15 \mathrm{~mL}$ na proporção de $1 \mathrm{~mL}$ de amostra para $4 \mathrm{~mL}$ de metanol. Os tubos foram presos em um suporte de isopor e colocados dentro um banho termostático contendo etilenoglicol 60\%, (FP 50-MA, da marca Julabo, Germany) a $-40^{\circ} \mathrm{C}$ (Figura 10). Foram realizados testes com três diferentes volumes de amostra, $1 \mathrm{~mL}, 2 \mathrm{~mL}$ e 
$5 \mathrm{~mL}$, a fim de verificar a influência na quantidade de formação do pellet e na concentração dos metabólitos intracelulares. As amostras foram coletadas rapidamente para dentro dos tubos contendo a solução de metanol ainda no banho à $-40^{\circ} \mathrm{C}$. Em seguida a mistura foi centrifugada em uma ultracentrífuga refrigerada (CR-22GIII, da marca Hitachi), a $5000 \mathrm{rpm}$ e $-9^{\circ} \mathrm{C}$ por 5 minutos. $\mathrm{O}$ sobrenadante foi descartado e o pellet resultante foi congelado imediatamente em nitrogênio líquido e estocado a $-80^{\circ} \mathrm{C}$ até a etapa de extração.

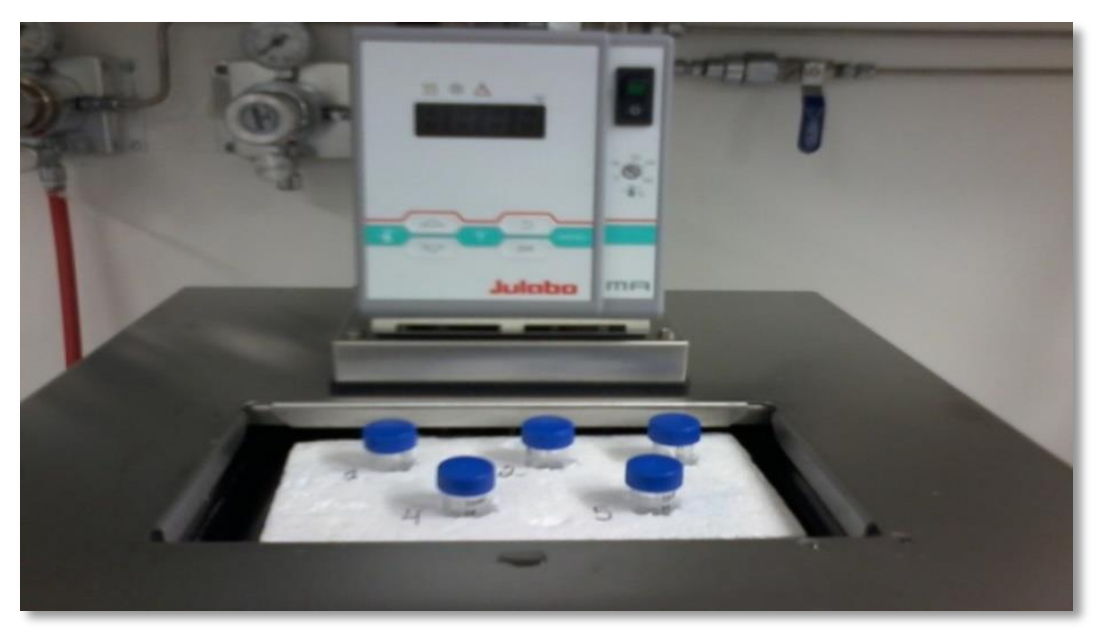

Figura 10. Banho termostático com os tubos falcon contendo a solução tampão de metanol.

Os metabólitos foram extraídos baseado no procedimento do etanol fervente adaptado de Bergdahl et al ${ }^{63}$. Uma solução tampão de etanol (75\% de etanol, $10 \mathrm{mM}$ de acetato de amônio, $\mathrm{pH} 7,4$ ) foi aquecida à aproximadamente $85^{\circ} \mathrm{C}$. Inicialmente as amostras foram retiradas do freezer a $-80^{\circ} \mathrm{C}$ e colocadas no banho termostático a $-40^{\circ} \mathrm{C}$, por 5 minutos. Em seguida foi adicionado etanol quente diretamente no pellet na proporção (1:1). As amostras foram homogeneizadas em um agitador orbital tipo vortex (Lab dancer da marca Ikawerke). A etapa subsequente consistiu na incubação da amostra por 3 minutos a $85^{\circ} \mathrm{C}$ com agitação vigorosa constante. Dois instrumentos para o processo de incubação foram testados: o banho metabólico tipo Dubnoff Reciprocante (MA 093, da marca Marconi) e o termoagitador para tubo eppendorf de $2 \mathrm{~mL}$ (Thermoximer comfort, da marca Eppendorf). 
Após esta etapa, as células foram resfriadas a $-40^{\circ} \mathrm{C}$ no banho termostático e centrifugadas em uma microcentrífuga refrigerada (5424-R da marca Eppendorf), a $5000 \mathrm{rpm} \mathrm{e}-9^{\circ} \mathrm{C}$ por 3 minutos. Os restos celulares foram descartados e o sobrenadante foi transferido para um novo tubo tipo eppendorf de $2 \mathrm{~mL}$. As amostras foram concentradas em um concentrador de amostras à vácuo (Centrivap DNA concentrator, da marca Labconco) e estocadas a $-80^{\circ} \mathrm{C}$.

\subsubsection{Reconstituição dos metabólitos para análise por UHPLC-MS}

Foram realizados testes para a escolha do solvente e do volume da reconstituição da amostra. Para tal as amostras foram reconstituídas em: i) 600 $\mu \mathrm{L}$ de uma solução acetonitrila/água (50/50) (v/v), ii) $175 \mu \mathrm{L}$ de $\mathrm{H}_{2} \mathrm{O}$ Milli-Q e iii) $200 \mu \mathrm{L}$ de $\mathrm{H}_{2} \mathrm{O}$ Milli-Q. Em seguida as amostras foram agitadas em vortex, e foram submetidas ao ultrassom por 5 minutos, a temperatura ambiente. As amostras foram centrifugadas em micro centrífuga de bancada (Mini Spin da marca Eppendorf) por 5 minutos a 13,4 rpm. Os sobrenadantes foram então separados e colocados em um vial do tipo total recovery e posteriormente analisados por UHPLC-MS/MS. 


\section{RESULTADOS}

E

DISCUSSÃO 


\section{RESULTADOS E DISCUSSÃO}

\subsection{Desenvolvimento de método por Espectrometria de Massas}

A primeira etapa no desenvolvimento do método analítico consistiu na obtenção dos espectros de massas (fullscan) de dezoito padrões de metabólitos (Figura 11) que compõem a via metabólica de fermentação da xilose.

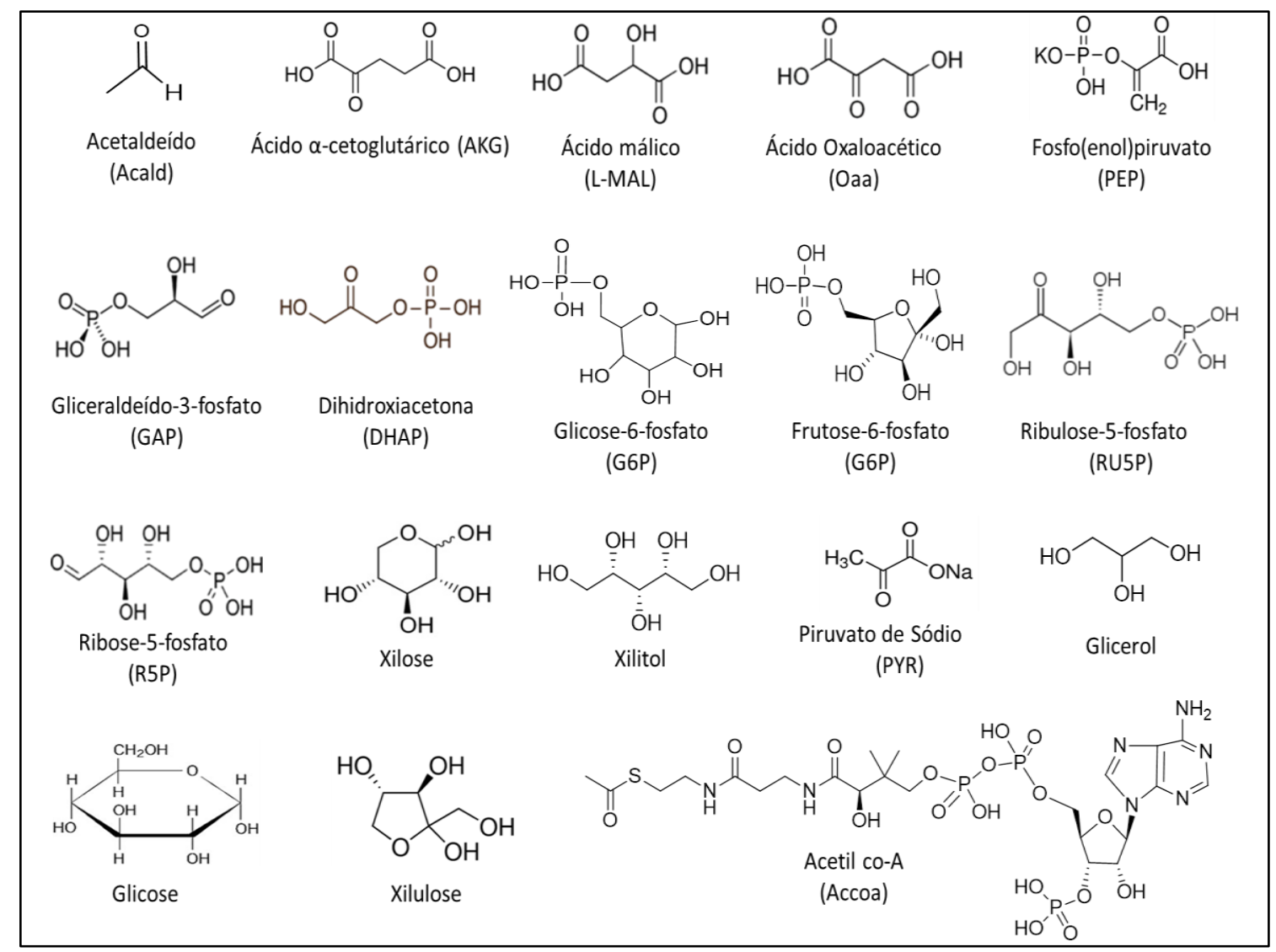

Figura 11. Estrutura química dos padrões analisados.

Inicialmente foi infundida a mistura dos padrões de metabólitos, nos modos de ionização ESI(+)-MS e ESI(-)-MS, sendo os espectros de massas adquiridos no modo fullscan (ou MS-Scan). Durante esses experimentos ficou evidenciado que a maior parte dos metabólitos ionizaram melhor por ESI(-)-MS, e portanto, o modo negativo foi selecionado para este trabalho. Os íons identificados no 
espectro de massas da mistura de padrões de metabólitos utilizando ESI(-)-MS (Figura 12), foram atribuídos aos íons precursores e são referentes aos metabólitos: L-MAL, AKG, PEP, GAP, Acooa, G6P ou F6P, R5P ou RU5P. Os demais metabólitos não foram detectados, provavelmente devido ao efeito de supressão iônica. Uma vez que todos os componentes da amostra são introduzidos simultaneamente na fonte de ionização, a intensidade do sinal de um composto facilmente ionizável pode ser tão intensa a ponto de suprimir a intensidade do sinal de um composto pouco ionizável.

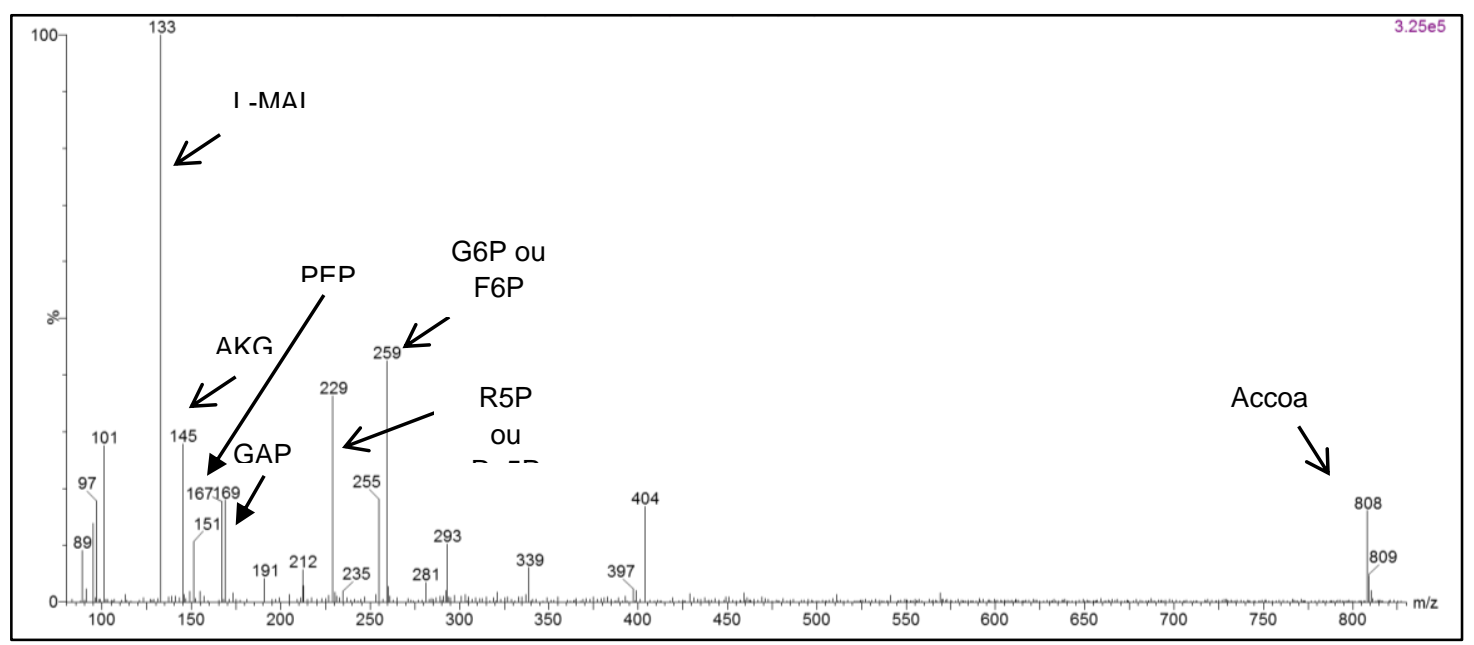

Figura 12. Espectro de massas por ESI(-)-MS da mistura dos padrões de metabólitos (ácido málico - L-MAL, ácido alfacetoglutárico - AKG, gliceraldeído3-fosfato - GAP, fosfo(enol)piruvato - PEP, glicose-6-fosfato - G6P, frutose-6fosfato - F6P, ribose-5-fosfato - R5P, ribulose-5-fosfato - Ru5P)

A fim de garantir uma melhor ionização para os 18 compostos de interesse e evitar o efeito de supressão iônica, cada metabólito foi infundido individualmente (dados não apresentados). Os parâmetros analíticos, como voltagem do capilar e cone, foram ajustados empiricamente a fim de obter a melhor condição de detecção para cada metabólito.

O capilar tem uma voltagem necessária para a formação dos íons nas fontes de ionização. Embora inicialmente tenha se tentado ajustá-lo, observouse que este parâmetro teve pouca influência na ionização dos metabólitos, não 
havendo ganho efetivo na intensidade do sinal detectado. Portanto, foi utilizado a voltagem de 3,5 KV para o capilar em todos os experimentos.

A voltagem do cone é fundamental na detecção do composto, pois há uma diferença de potencial entre o capilar e o cone, a qual atrai os íons com carga oposta para dentro do espectrômetro de massas. Caso a voltagem do cone esteja muito alta, o íon pode fragmentar na fonte, e, portanto, não ser detectado com sua razão massa/carga $(\mathrm{m} / \mathrm{z})$. As condições otimizadas do cone para cada metabólito analisado nos modos de ionização negativo estão descritas na Tabela 11.

Tabela 11. Valores experimentais da voltagem do cone dos padrões de metabólitos nos modo ESI(-)-MS.

\begin{tabular}{|c|c|}
\hline Composto & $\begin{array}{c}\text { Cone } \\
\text { (V) }\end{array}$ \\
\hline ACCOA & 60 \\
\hline AKG & 18 \\
\hline L-MAL & 18 \\
\hline Oaa & 15 \\
\hline Acald & 20 \\
\hline DHAP & 25 \\
\hline F6P & 32 \\
\hline PEP & 20 \\
\hline G6P & 32 \\
\hline Glicerol & 18 \\
\hline GAP & 20 \\
\hline Glicose & 15 \\
\hline PYR & 20 \\
\hline R5P & 30 \\
\hline RU5P & 30 \\
\hline Xilose & 10 \\
\hline Xilitol & 25 \\
\hline Xylu & 10 \\
\hline & \\
\hline &
\end{tabular}




\subsubsection{Espectrometria de massas tandem (MS/MS) e Multiple Reaction Monitoring (MRM)}

Os pares de isômeros F6P/G6P, R5P/RU5P, GAP/DHAP, Xilose/Xylu, são indistinguíveis através de experimentos MS, já que os valores de $\mathrm{m} / \mathrm{z}$ dos íns precursores gerados são os mesmos. Desta forma a espectrometria de massas tandem (MS/MS) é uma estratégia valiosa, desde que os isômeros apresentem um perfil de fragmentação diferente.

Os experimentos de MS/MS foram realizados ajustando-se os valores da energia de colisão para cada analito de interesse a fim de obter o valor de $\mathrm{m} / \mathrm{z}$ do íon fragmento mais intenso e/ou seletivo. A partir destas informações o método MRM foi configurado.

O aumento da energia de colisão acelera os íons e consequentemente ocorre o aumento da intensidade dos choques entre ele e o gás presente na cela de colisão. Isto pode acarretar na formação de vários fragmentos advindos de uma mesma molécula. No caso de experimentos de MRM é importante que haja a formação de um fragmento específico da molécula e que esteja em alta intensidade após o experimento de MS/MS.

A figura 13 mostra dois espectros de massas por ESI(-)-MS/MS para o padrão DHAP. Para o primeiro experimento foi utilizado energia de colisão 10 $\mathrm{eV}$ e para o segundo experimento a energia utilizada foi de $18 \mathrm{eV}$. O espectro de massas referente à energia de colisão $10 \mathrm{eV}$ (Figura 13a) apresentou um único íon fragmento mais intenso $\circ \mathrm{m} / \mathrm{z} 96.8$, enquanto que o espectro de massas referente a energia de colisão $18 \mathrm{eV}$ (Figura 13b) apresentou dois íons fragmentos intensos $\mathrm{m} / \mathrm{z} 96.9$ e $\mathrm{m} / \mathrm{z} 78.8$, sendo este último o mesmo íon fragmento observado para o PEP (Figura 13c). Portanto, neste caso a condição experimental utilizando a energia de colisão de $10 \mathrm{eV}$ foi determinada para os experimentos de MRM para detecção do DHAP. 
a)

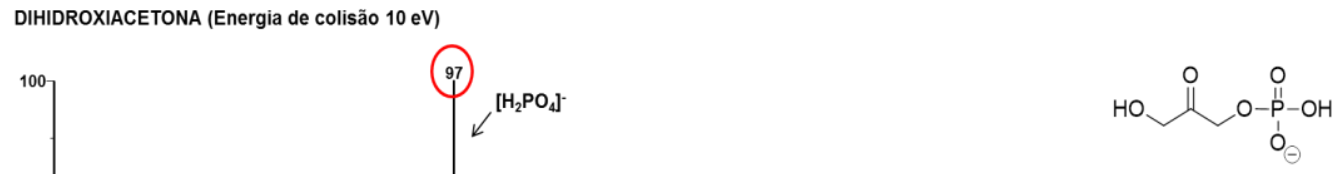

b)

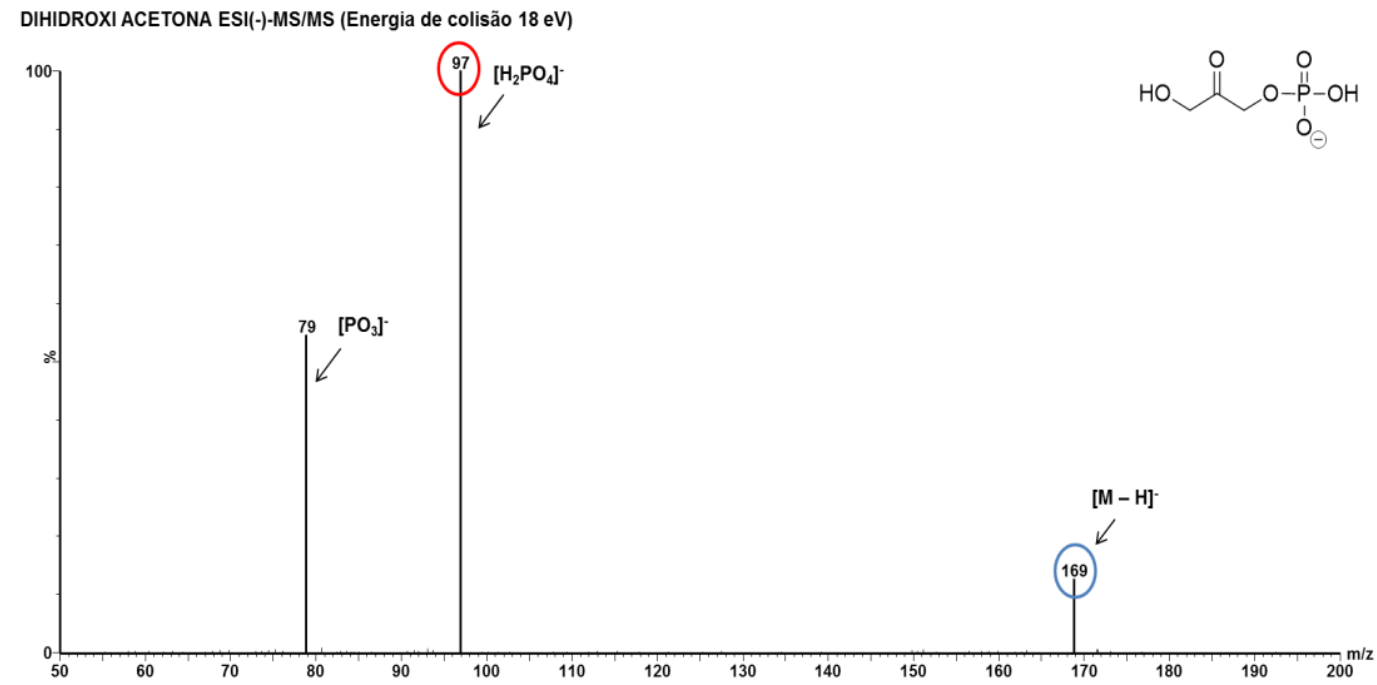

c)

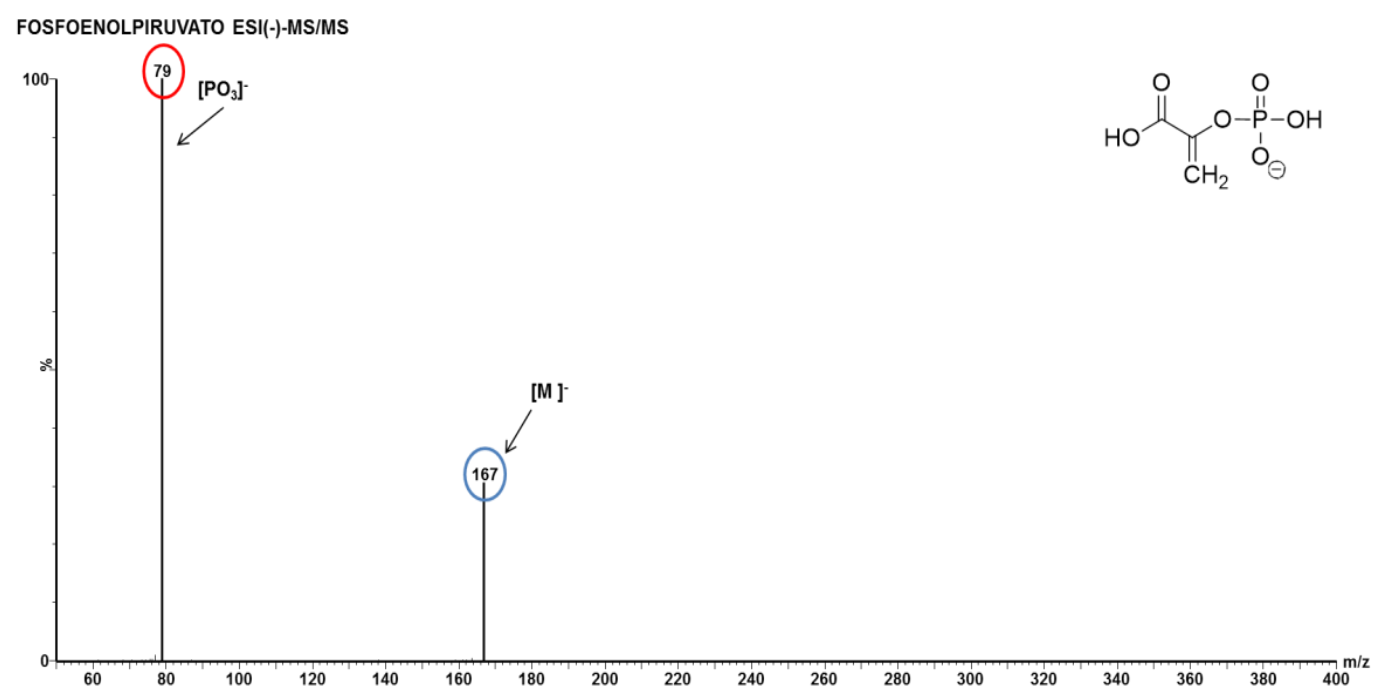

Figura 13. Espectros de massas por ESI(-)-M (c) ; do metabólito DHAP: a) energia de colisão $10 \mathrm{eV}$ b) energia de colisão $18 \mathrm{eV}$. c) Espectro de massas por ESI(-)-MS/MS do metabólito PEP com energia de colisão 10 eV. 
Os metabólitos que contém o grupo fosfato geram os fragmentos: $\mathrm{m} / \mathrm{z} 97 \mathrm{e}$ $\mathrm{m} / \mathrm{z} 79$, estes correspondem aos íons $\left[\mathrm{H}_{2} \mathrm{PO}_{4}\right]^{-}$e $\left[\mathrm{PO}_{3}\right]^{-}$, respectivamente. Já para os ácidos orgânicos em geral, o padrão de fragmentação é a descarboxilação e/ou a eliminação de água. ${ }^{64}$

A fragmentação de compostos com estruturas similares implica em transições não específicas, o que pode dificultar a identificação e quantificação dos analitos na amostra. $O$ ácido oxaloacético, por exemplo, possui íon molecular $m / z 131\left([\mathrm{M}-\mathrm{H}]^{-}\right)$e íon fragmento $\mathrm{m} / \mathrm{z} 87$ ([M-H-44]) (Figura 16), resultado da perda da molécula de gás carbônico. $O$ aumento na energia de colisão pode gerar outro íon fragmento $\mathrm{m} / \mathrm{z} 43$ devido à perda de $\mathrm{CO}_{2}$. No entanto a mesma transição $87 \rightarrow 43$ ocorre com o piruvato (Figura 25).

A Tabela 12 apresenta os parâmetros analíticos otimizados no espectrômetro de massas, para todos os métodos analisados, incluindo: $\mathrm{m} / \mathrm{z}$ íon precursor, $\mathrm{m} / \mathrm{z}$ íon fragmento e energia de colisão. Os valores de $\mathrm{m} / \mathrm{z}$ dos íons fragmentos $[\mathrm{M}-\mathrm{H}]^{-}$mais intensos e da energia de colisão foram comparados e estão condizentes com os encontrados na literatura.

Dentre os 18 padrões analisados, quatro compostos não puderam ser testados nos métodos cromatográficos: acetaldeído, acetil co-enzima $A$, ribulose-5-fosfato e ácido oxaloacético. O íon fragmento do padrão acetaldeído não pode ser identificado no espectro de massas, tendo em vista que o valor $m / z$ do íon precursor $(59,7)$, por ser muito baixo, sofre interferência do solvente e de contaminantes comuns nesta faixa de massas. Os padrões acetil coenzima $A$, ribulose-5-fosfato e ácido oxaloacético sofreram o processo de degradação e desta forma não puderam ser utilizados. Sendo assim catorze padrões de metabólitos foram testados para o desenvolvimento do método cromatográfico. 
Tabela 11. Condições experimentais otimizadas para experimentos de MRM dos padrões de metabólitos utilizando ESI(-)-MS/MS.

\begin{tabular}{|c|c|c|c|}
\hline Composto & Q1 $(\mathbf{m} / \mathbf{z})$ & Q3 $(\mathbf{m} / \mathbf{z})$ & $\begin{array}{c}\text { Energia de Colisão } \\
(\mathbf{e V})\end{array}$ \\
\hline ACCOA & 808.1 & 408 & 40 \\
\hline AKG & 144.6 & 56.8 & 15 \\
\hline L-MAL & 132.6 & 114.8 & 10 \\
\hline Oaa & 130.8 & 86.8 & 6 \\
\hline Acald & 59.7 & Não detectado & - \\
\hline DHAP & 169 & 97 & 18 \\
\hline F6P & 258.6 & 96.8 & 18 \\
\hline PEP & 166.6 & 78.8 & 10 \\
\hline G6P & 258.7 & 96.8 & 20 \\
\hline Glicerol & 91.0 & 59.1 & 18 \\
\hline GAP & 168.8 & 96.8 & 18 \\
\hline Glicose & 179.1 & 58.9 & 18 \\
\hline PYR & 86.8 & 42,8 & 8 \\
\hline R5P & 228.8 & 96.8 & 20 \\
\hline RU5P & 228.8 & 79.0 & 20 \\
\hline Xilose & 148.9 & 59.0 & 14 \\
\hline Xilitol & 151.0 & 58.9 & 20 \\
\hline Xylu & 149.0 & 59.0 & 14 \\
\hline
\end{tabular}

O objetivo desta etapa foi otimizar os parâmetros do espectrômetro de massas para cada metabólito e desenvolver o método MRM a fim de obter um método cromatográfico com maior seletividade e sensibilidade. Os espectros de massas ESI(-)-MS/MS dos padrões de metabólitos estão apresentados nas figuras 14 a 30 , os valores de $\mathrm{m} / \mathrm{z}$ circulados em azul correspondem aos íons precursores e os valores $\mathrm{m} / \mathrm{z}$ circulados em vermelho correspondem aos íons fragmentos selecionados para o MRM. 


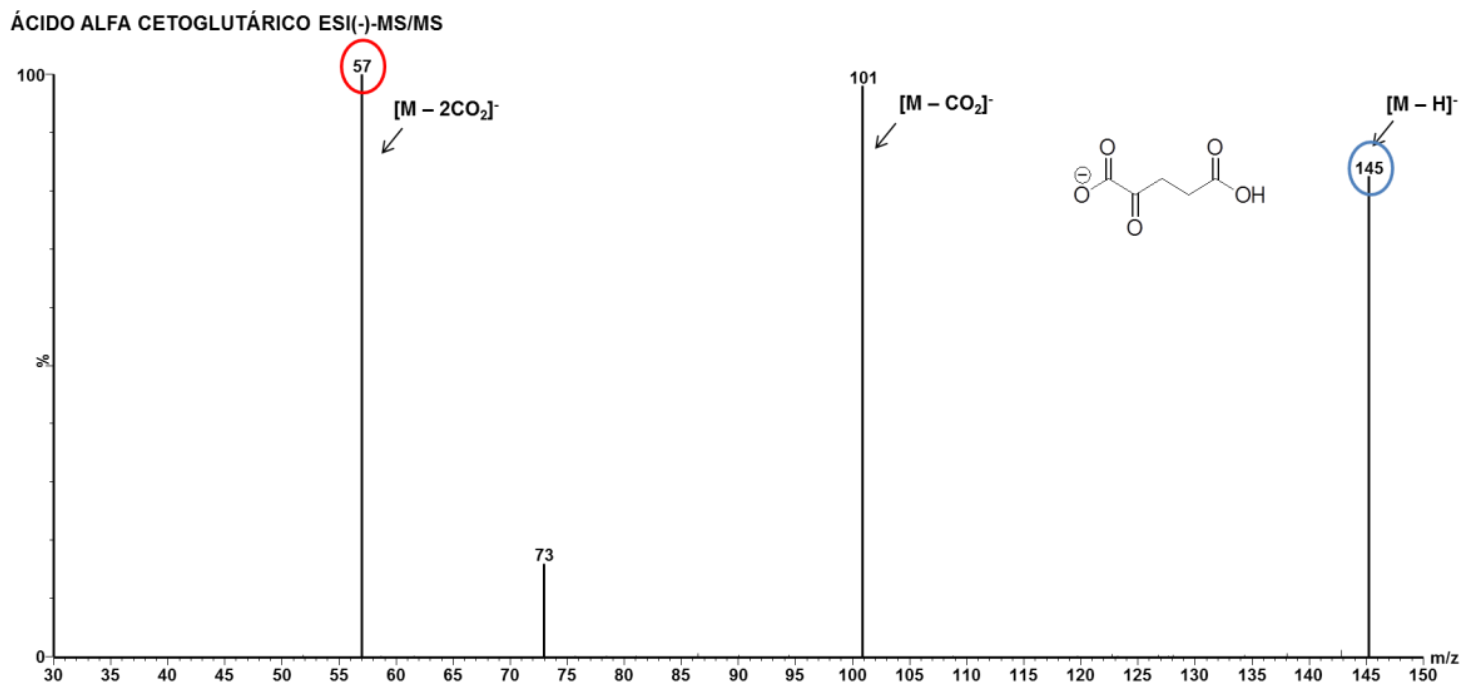

Figura 14. Espectro de massas por ESI(-)-MS/MS do padrão ácido alfa cetoglutárico ( $m / z$ 145) (energia de colisão 15 eV).

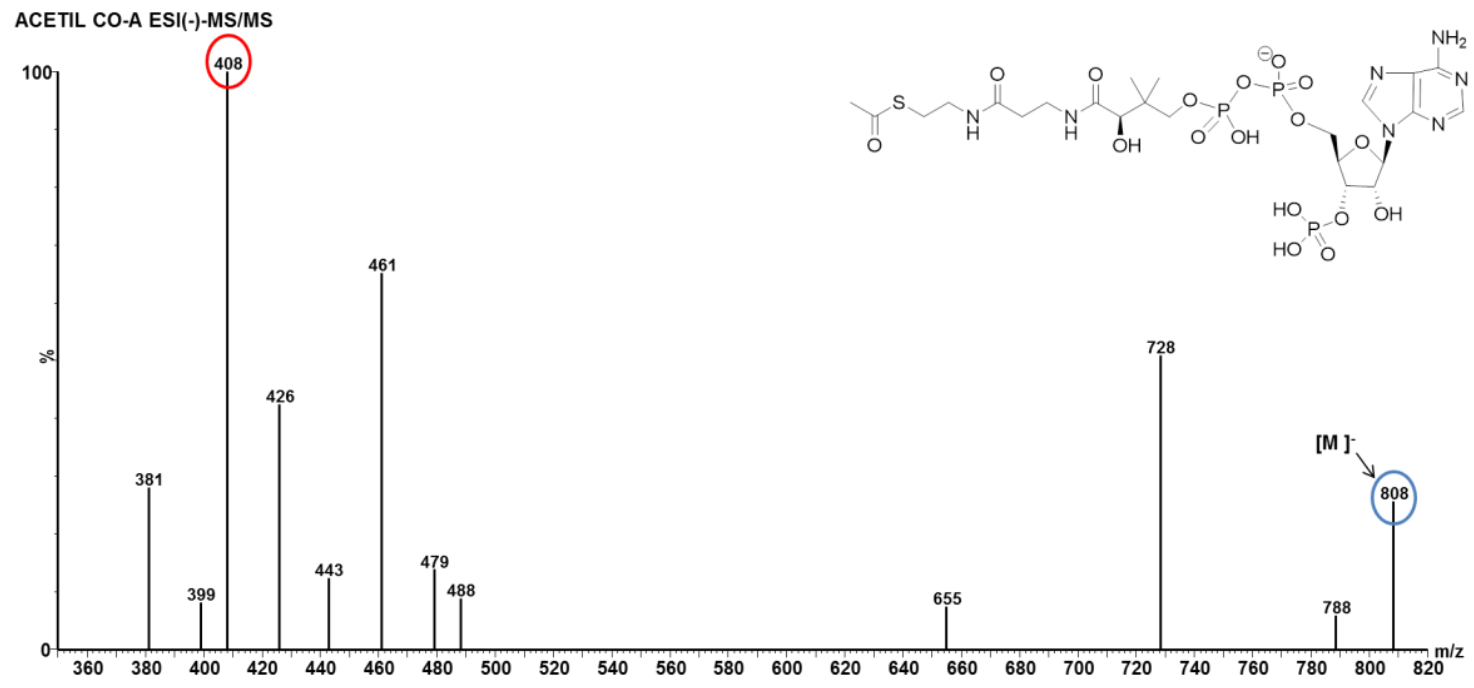

Figura 15. Espectro de massas por ESI(-)-MS/MS do padrão acetil co-a $(\mathrm{m} / \mathrm{z}$ 808) (energia de colisão 40 eV). 


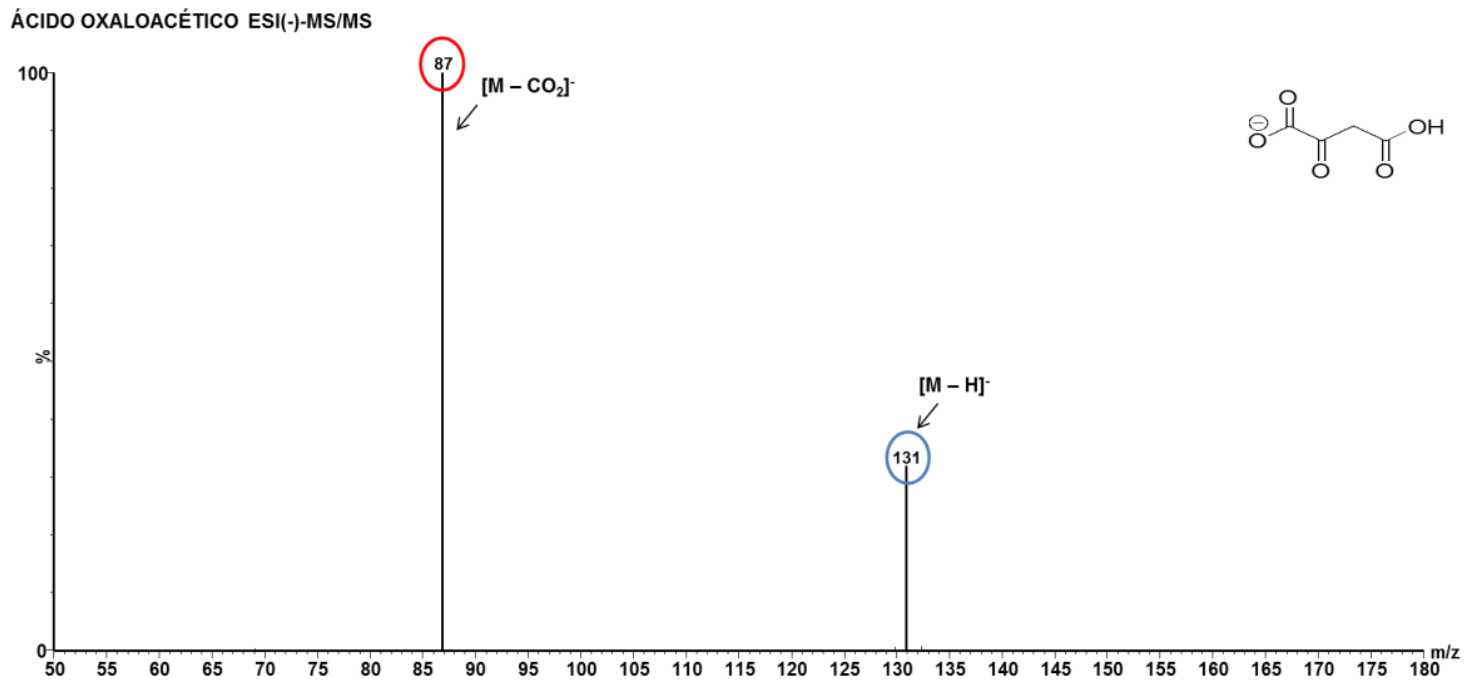

Figura 16. Espectro de massas por ESI(-)-MS/MS do padrão ácido oxaloacético $(\mathrm{m} / \mathrm{z} 131)$ (energia de colisão $6 \mathrm{eV})$.

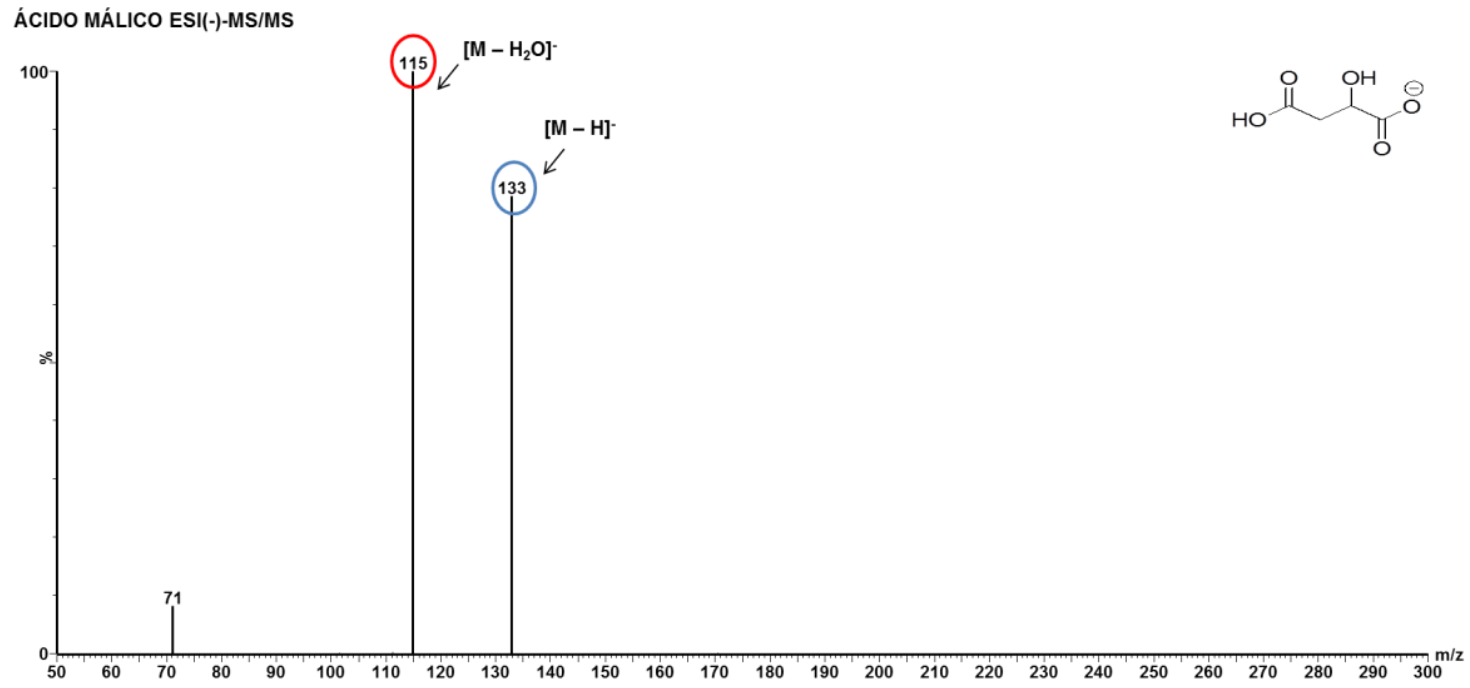

Figura 17. Espectro de massas por ESI(-)-MS/MS do padrão ácido málico ( $\mathrm{m} / \mathrm{z}$ 133) (energia de colisão $10 \mathrm{eV}$ ). 
DIHIDROXI ACETONA ESI(-)-MS/MS

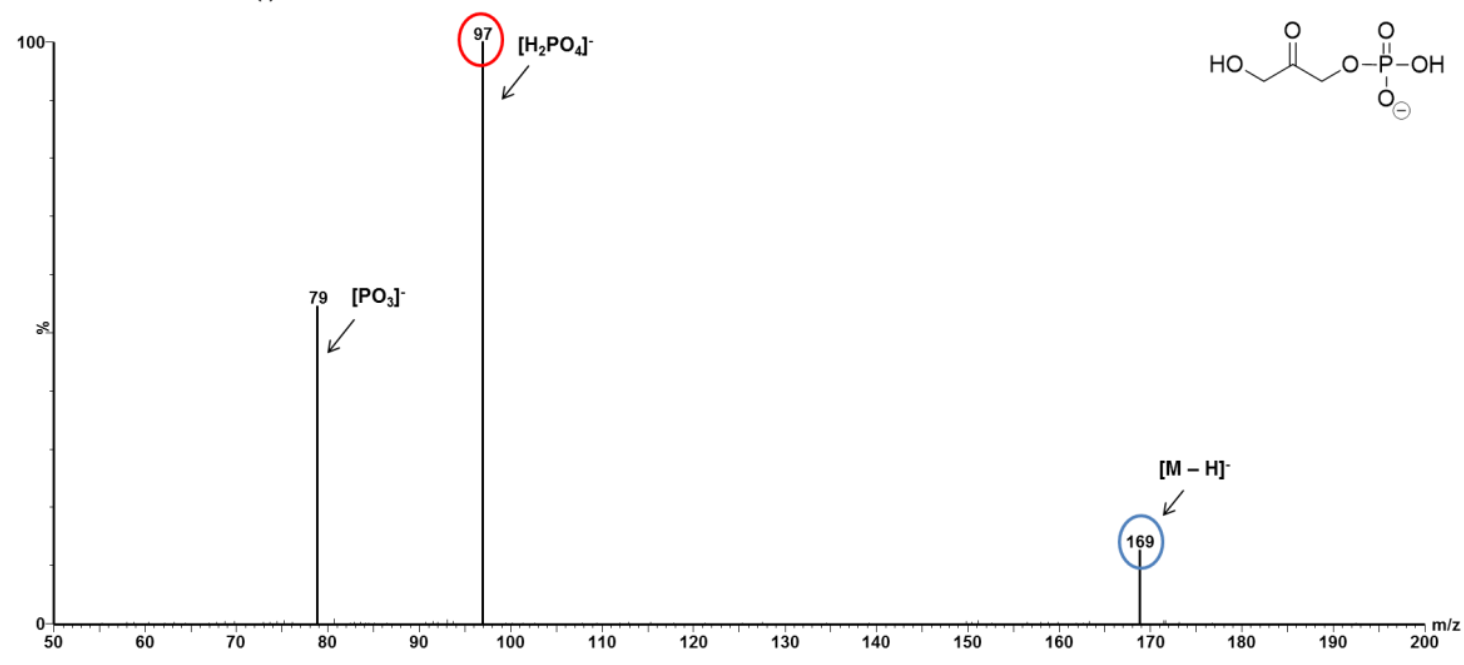

Figura 18. Espectro de massas por ESI(-)-MS/MS do padrão dihidroxiacetona fosfato $(\mathrm{m} / \mathrm{z} 169)$ (energia de colisão $18 \mathrm{eV}$ ).

FOSFOENOLPIRUVATO ESI(-)-MS/MS

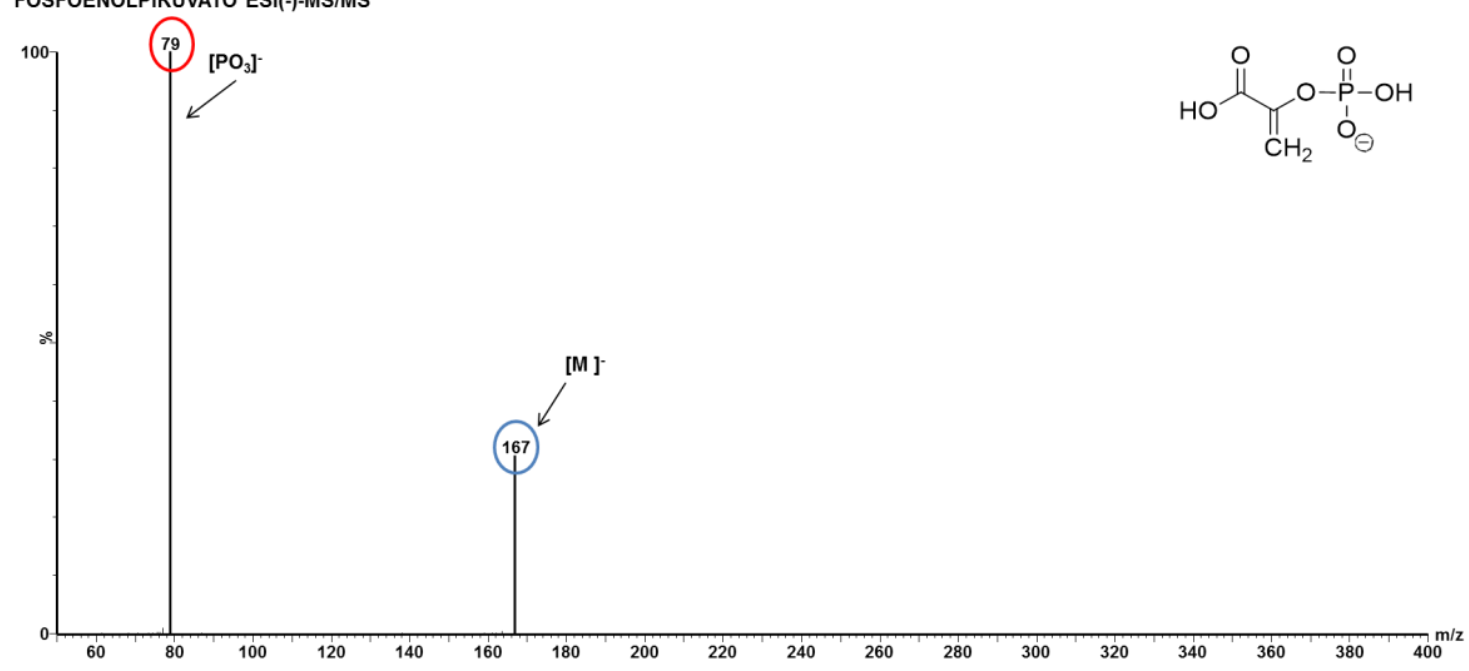

Figura 19. Espectro de massas por ESI(-)-MS/MS do padrão fosfo(enol)piruvato $(\mathrm{m} / \mathrm{z} 167)$ (energia de colisão $10 \mathrm{eV}$ ). 
FRUTOSE-6-FOSFATO ESI(-)-MS/MS

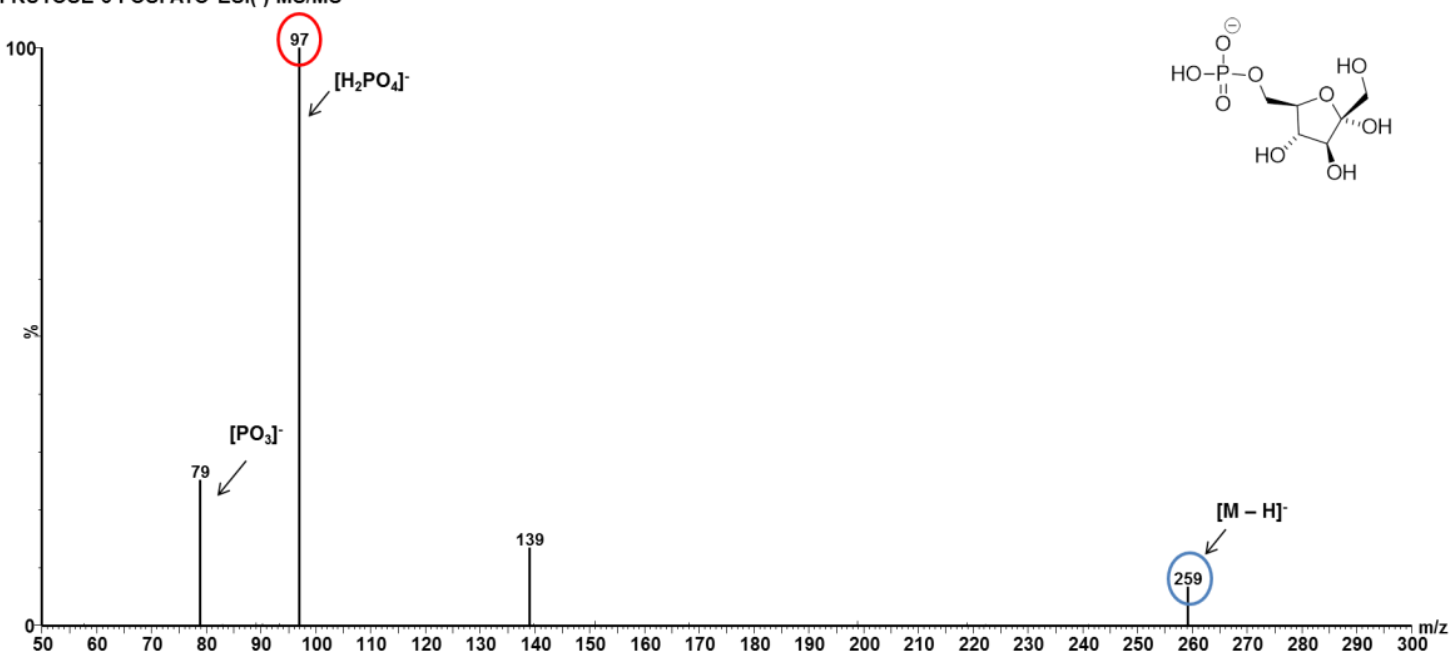

Figura 20. Espectro de massas por ESI(-)-MS/MS do padrão frutose-6-fosfato ( $m / z$ 259) (energia de colisão $18 \mathrm{eV}$ ).

GLICOSE-6-FOSFATO ESI(-)-MS/MS

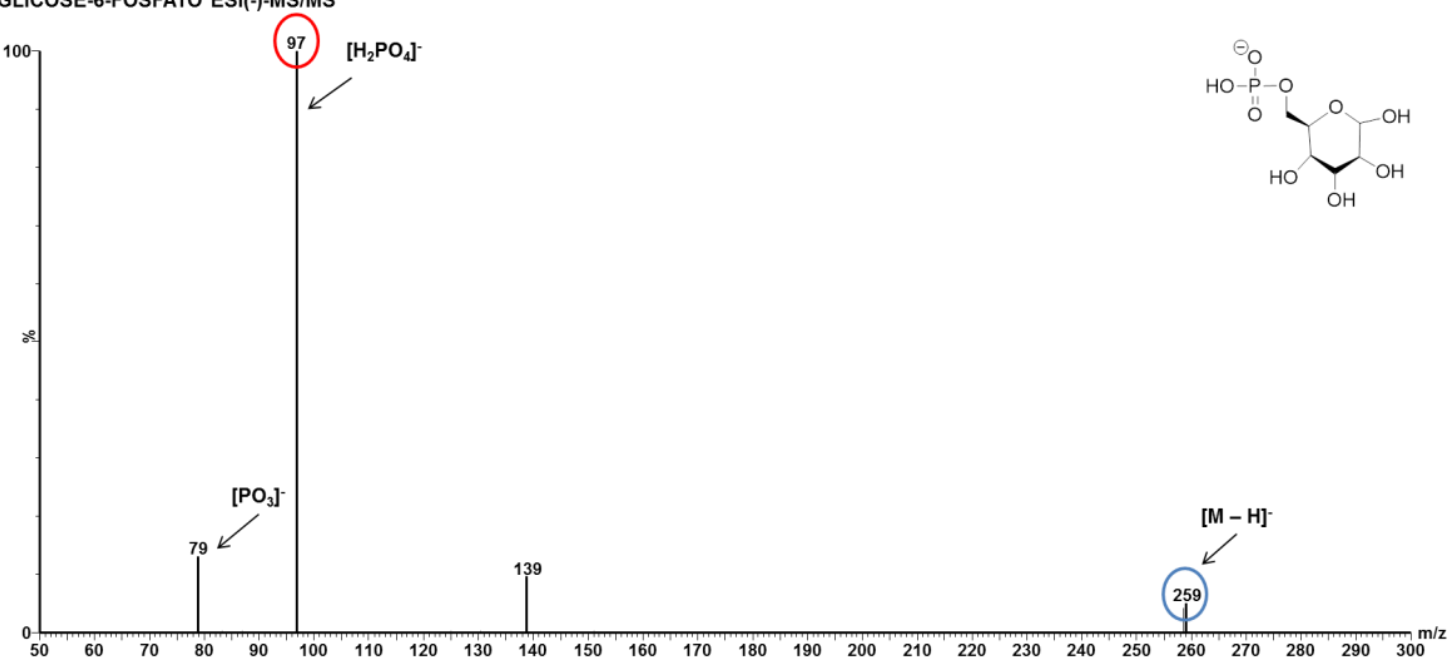

Figura 21. Espectro de massas por ESI(-)-MS/MS do padrão glicose-6-fosfato ( $m / z$ 259) (energia de colisão $20 \mathrm{eV}$ ). 


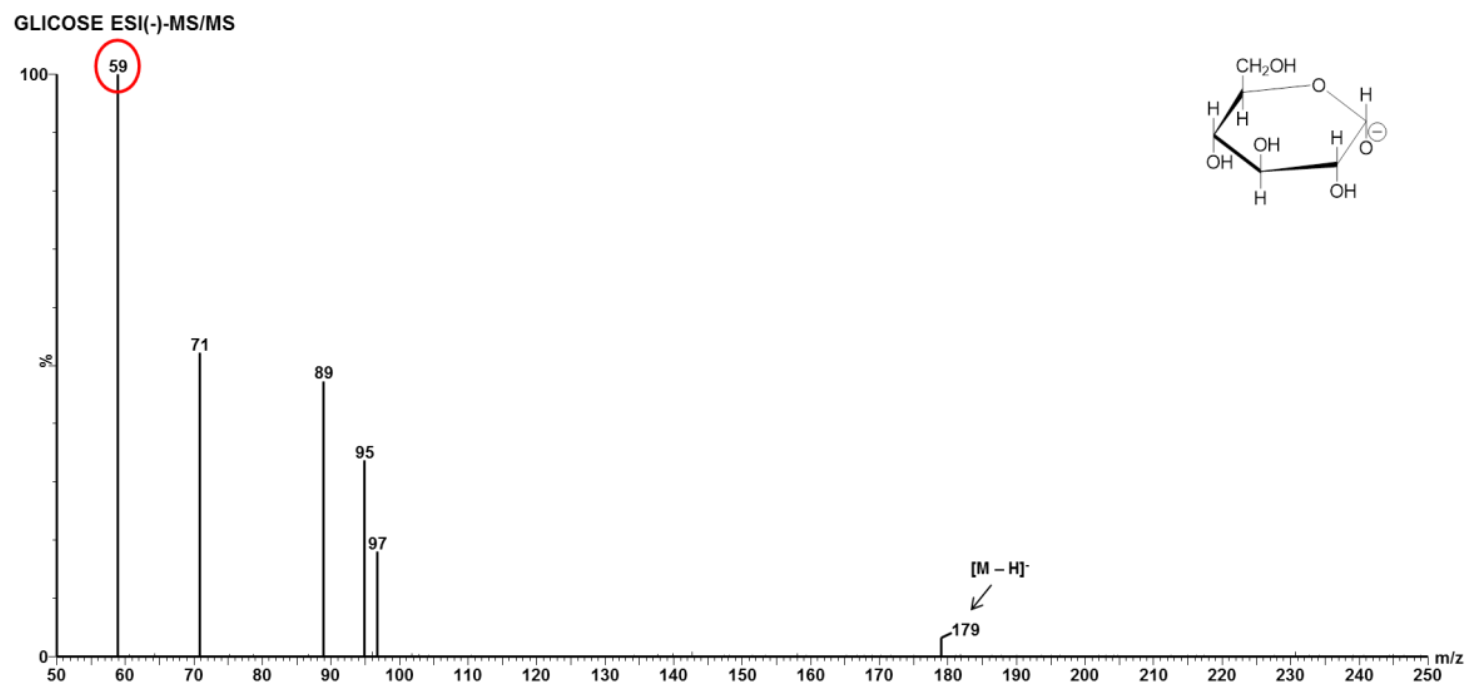

Figura 22. Espectro de massas por ESI(-)-MS/MS do padrão glicose $(\mathrm{m} / z$ 179) (energia de colisão $18 \mathrm{eV}$ ).

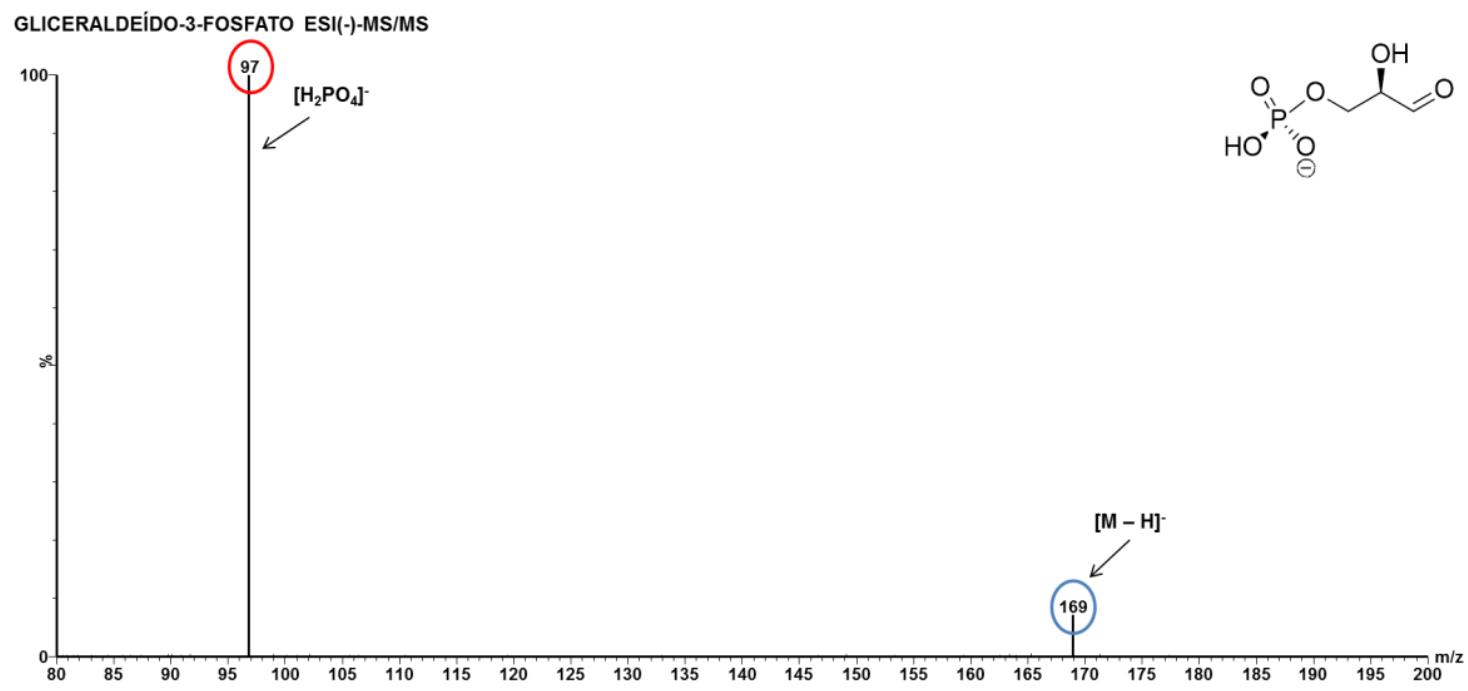

Figura 23. Espectro de massas por ESI(-)-MS/MS do padrão gliceraldeído-3fosfato $(m / z 169)$ (energia de colisão $18 \mathrm{eV})$. 


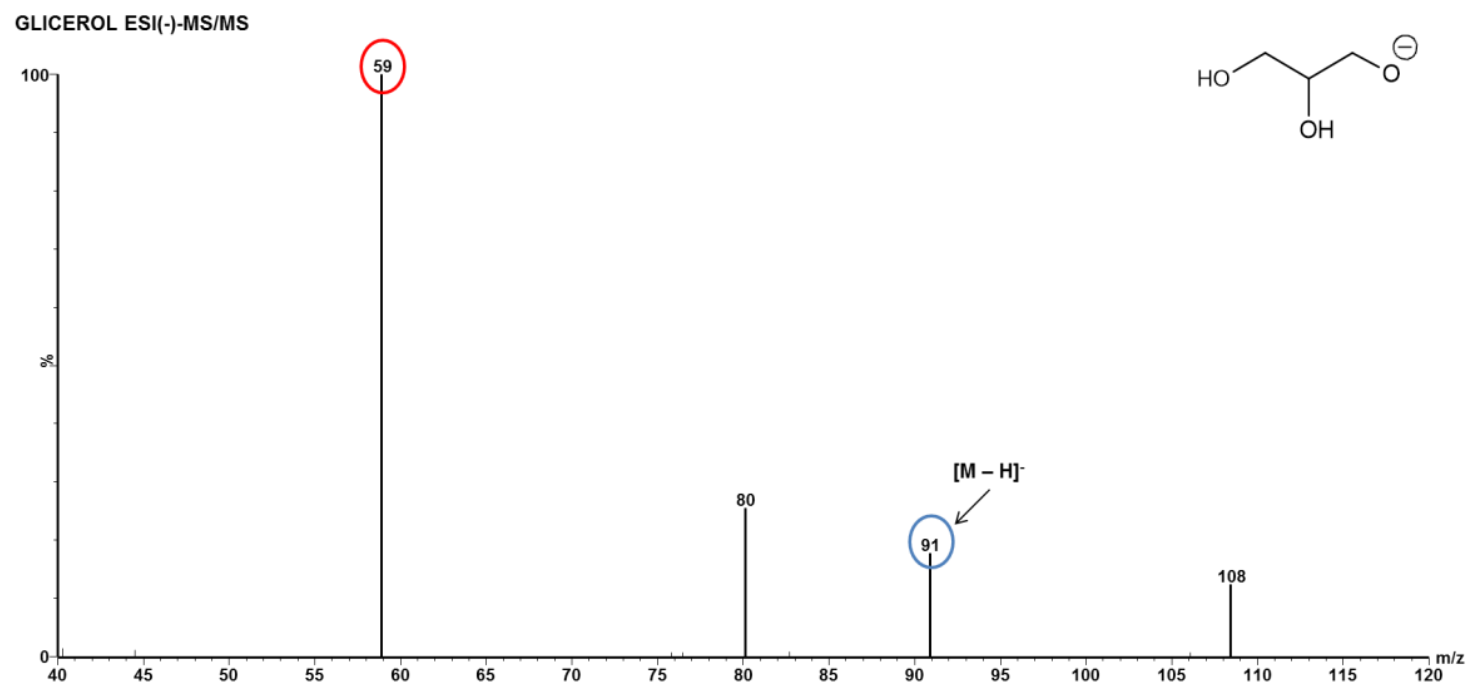

Figura 24. Espectro de massas por ESI(-)-MS/MS do padrão glicerol $(\mathrm{m} / \mathrm{z} 91)$ (energia de colisão $18 \mathrm{eV}$ ).

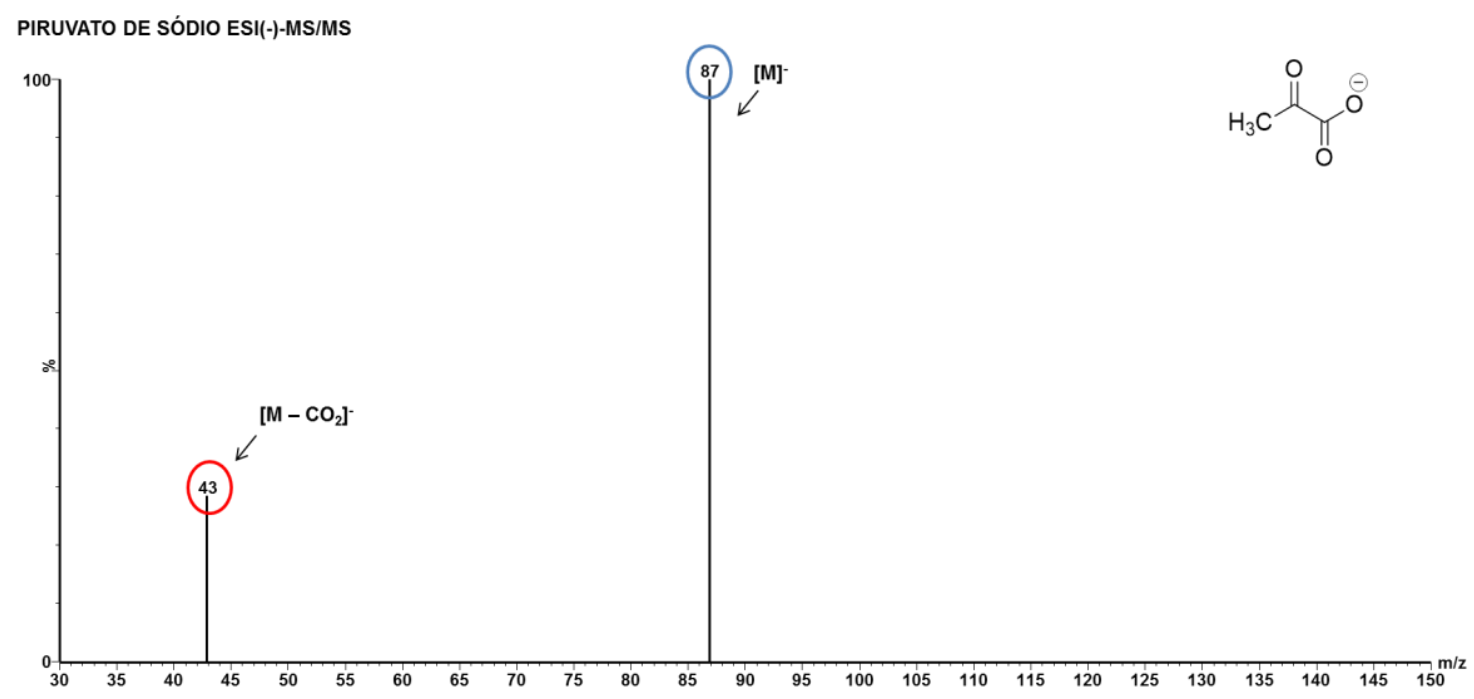

Figura 25. Espectro de massas por ESI(-)-MS/MS do padrão piruvato de sódio $(\mathrm{m} / \mathrm{z} 87)$ (energia de colisão $8 \mathrm{eV}$ ). 
RIBULOSE-5-FOSFATO ESI(-)-MS/MS

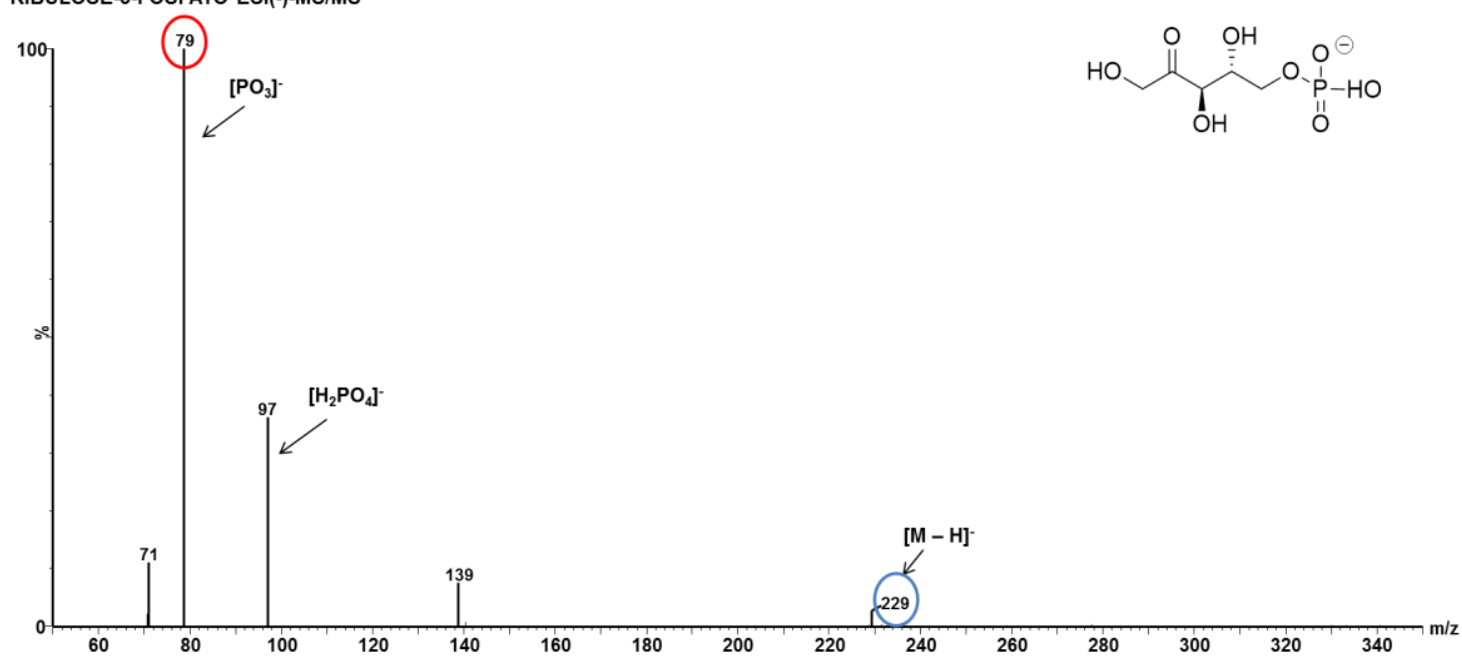

Figura 26. Espectro de massas por ESI(-)-MS/MS do padrão ribulose-5-fosfato ( $m / z$ 229) (energia de colisão $20 \mathrm{eV}$ ).

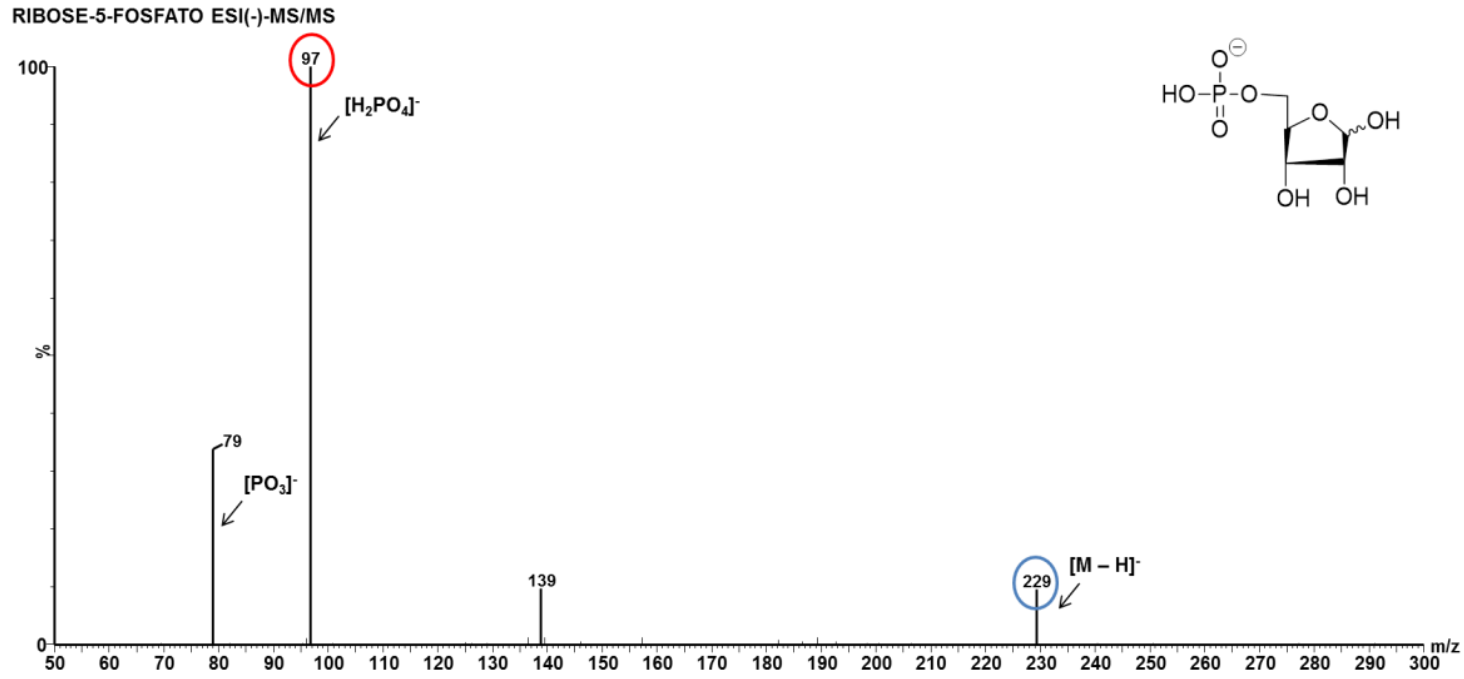

Figura 27. Espectro de massas por ESI(-)-MS/MS do padrão ribose-5-fosfato ( $m / z$ 229) (energia de colisão $20 \mathrm{eV}$ ). 
XILOSE ESI(-)- MS/MS

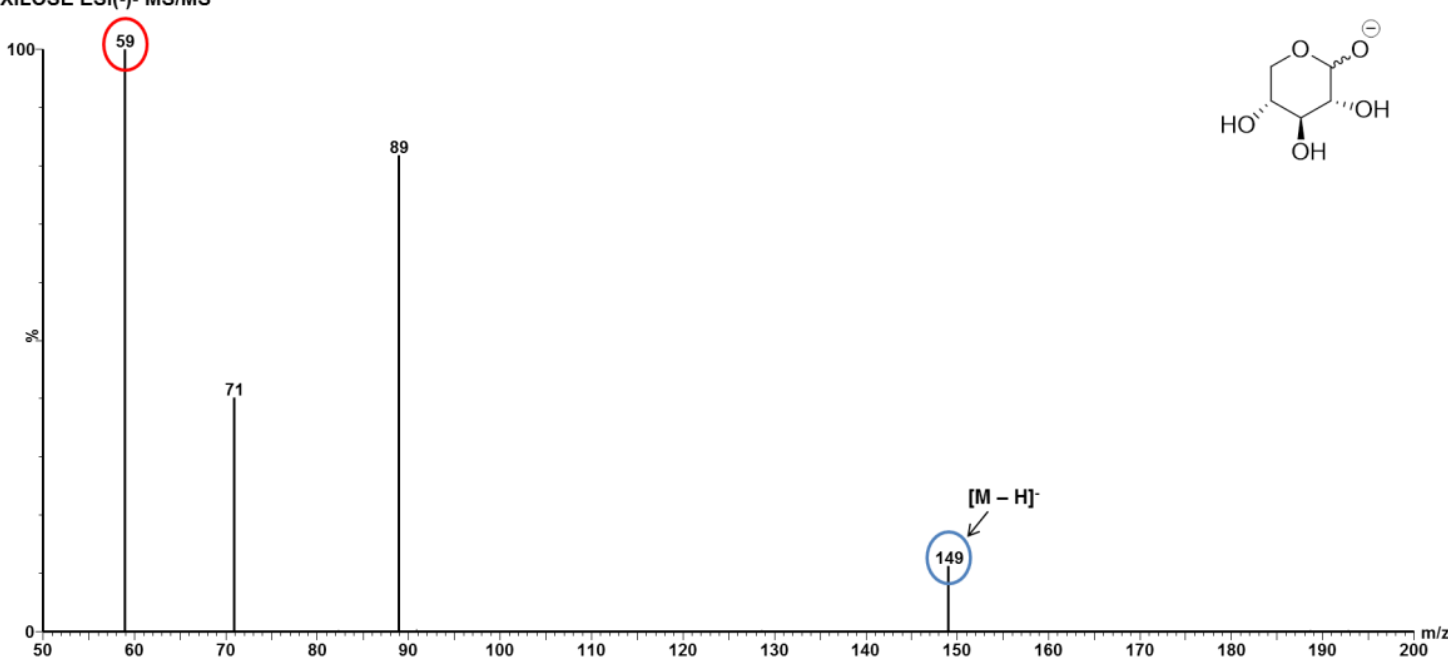

Figura 28. Espectro de massas por ESI(-)-MS/MS do padrão xilose $(m / z 149)$ (energia de colisão $14 \mathrm{eV}$ ).

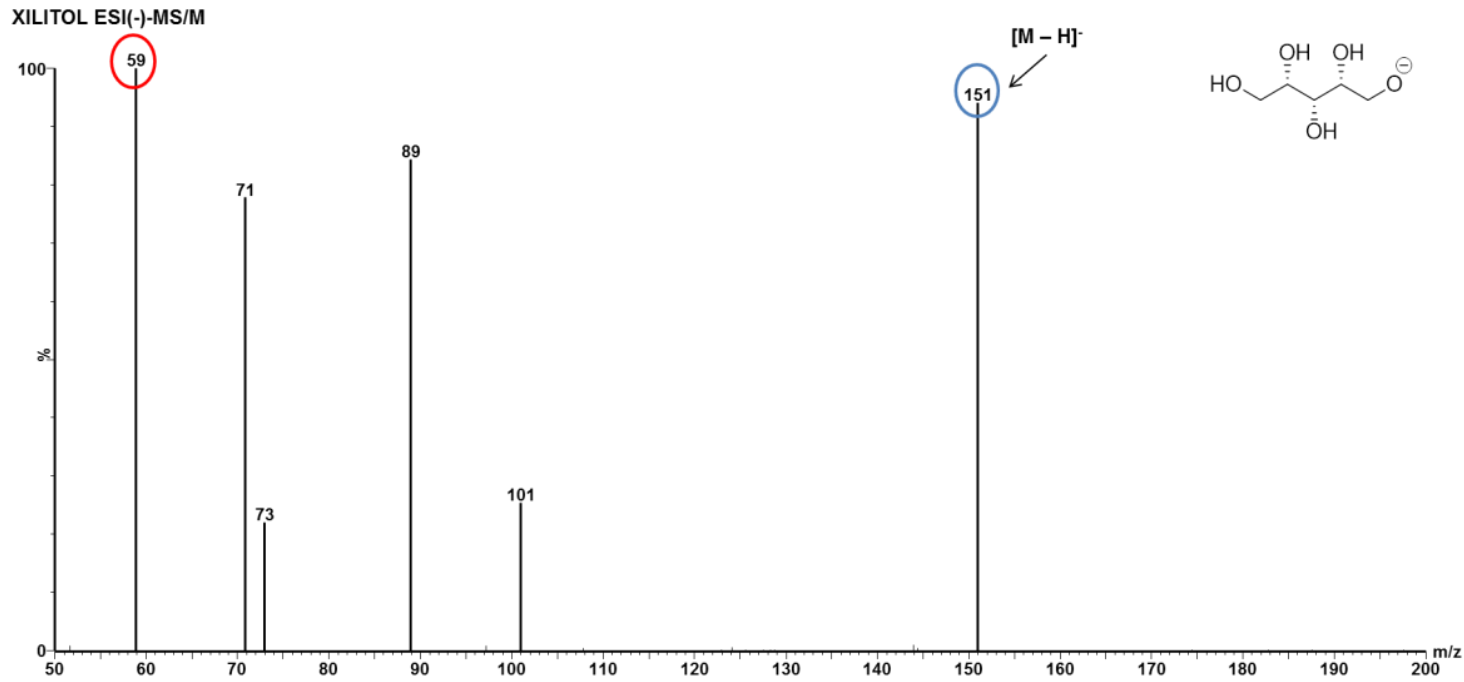

Figura 29. Espectro de massas por ESI(-)-MS/MS do padrão xilitol $(\mathrm{m} / \mathrm{z} 151)$ (energia de colisão $20 \mathrm{eV}$ ). 


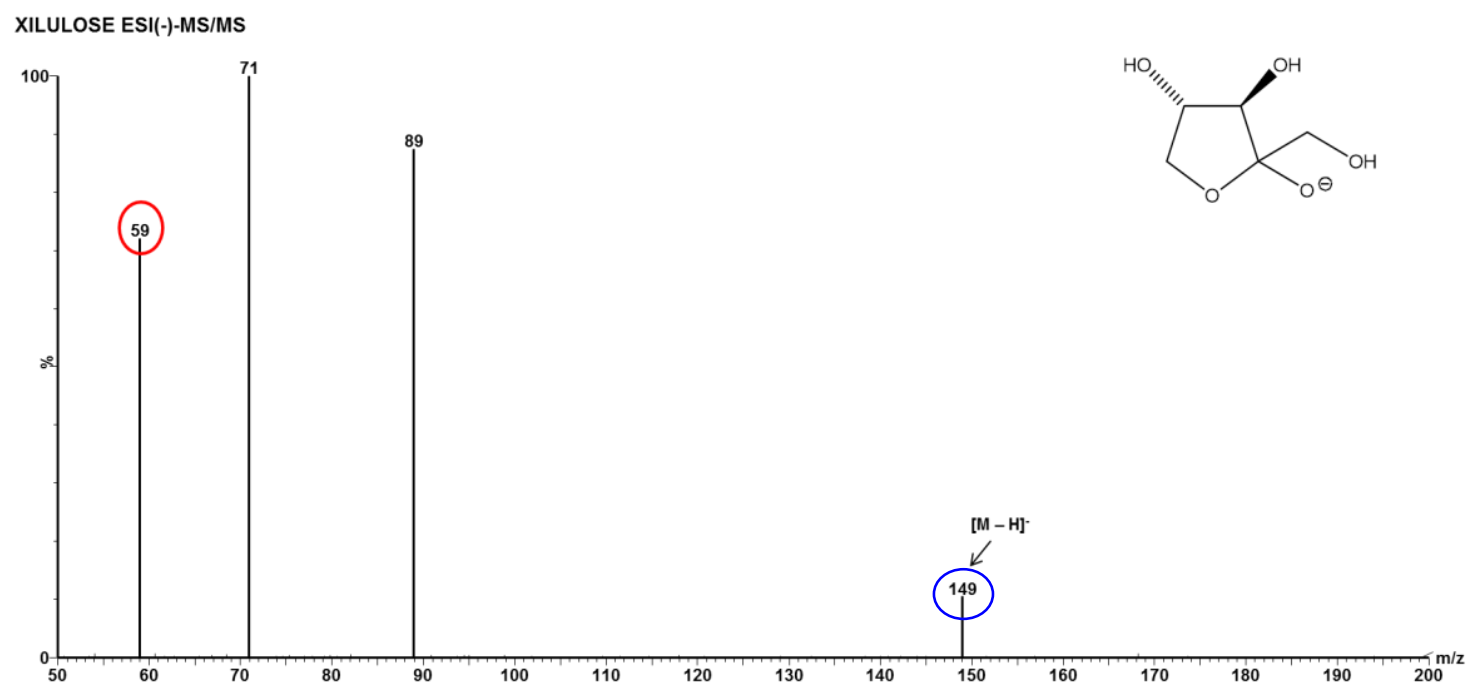

Figura 30. Espectro de massas por ESI(-)-MS/MS do padrão xilulose ( $\mathrm{m} / \mathrm{z}$ 149) (energia de colisão 14 eV).

\subsection{Desenvolvimento do método por UHPLC-MS}

Após a otimização do método MS, a próxima etapa consistiu na seleção do método cromatográfico. Para tal foram testados três diferentes modos de separação, os quais estão apresentados a seguir.

\subsubsection{Cromatografia de interação Hidrofílica (HILIC - Hydrophilic Interaction Liquid Chromatography)}

O método HILIC foi desenvolvido utilizando a coluna BEH Amida (Waters) e testando-se diferentes composições de fase móvel, em modo gradiente e isocrático, variando-se a temperatura e valores de $\mathrm{pH}$. Inicialmente o potencial da coluna amida foi testado para a separação de catorze padrões de metabólitos, incluindo os açúcares fosfatados, os ácidos orgânicos, monossacarídeos e álcoois. Em geral, na cromatografia HILIC utiliza-se como 
solvente de eluição a mistura de água e acetonitrila a qual são adicionados sais de amônio como modificador. Para este trabalho foram testados dois principais sais utilizados por $\mathrm{Li}$ et $a^{\beta 6}$ : formiato de amônio e acetato de amônio, adicionados nas soluções em diferentes proporções de acetonitria e água. Além destes foram testados também gradientes de eluição com hidróxido de amônio em água como fase $A$, e hidróxido de amônio em acetonitrila como fase B.

A Figura 31 apresenta três composições diferentes de fase móvel testada para a separação de uma mistura contendo catorze padrões de metabólitos (PYR, glicerol, L-MAL, AKG, xilose, Xylu, xilitol, PEP, GAP, DHAP, glicose, R5P, G6P e F6P), sendo: a) A: hidróxido de amônio 0,1\% B: ACN + hidróxido de amônio $0,1 \%$, b) $\mathrm{A}: \mathrm{ACN} / \mathrm{H}_{2} \mathrm{O} 50 / 50$ + acetato de amônio $10 \mathrm{mM}$ B: $\mathrm{ACN} / \mathrm{H}_{2} \mathrm{O} 90 / 10$ + acetato de amônio $10 \mathrm{mM}$ e c) $\mathrm{A}$ : $\mathrm{ACN} / \mathrm{H}_{2} \mathrm{O} 90 / 10$ + formiato de amônio $5 \mathrm{mM}$ + hidróxido de amônio 0.1\% B: ACN/ $\mathrm{H}_{2} \mathrm{O}$ 10/90 + formiato de amônio $5 \mathrm{mM}+$ hidróxido de amônio $0.1 \%$.

O cromatograma obtido com o uso do hidróxido de amônio $0,1 \%$ em modo gradiente (Figura 31a), apresentou boa separação apenas para os compostos neutros: glicerol, xilulose, xilose, xilitol e glicose. No entanto os compostos fosfatados e os ácidos málico e alfa cetoglutárico não foram separados. Utilizando-se o acetato de amônio (Figura 31b) os isômeros não separaram e diversos compostos co-eluiram. Por exemplo, nota-se a co-eluição do ácido málico e da di-hidroxiacetona quando utilizou-se o acetato de amônio na fase móvel. Com o uso do formiato de amônio como modificador, além da co-eluição de diversos desses padrões, alguns não foram identificados (Figura 31c). 
a)

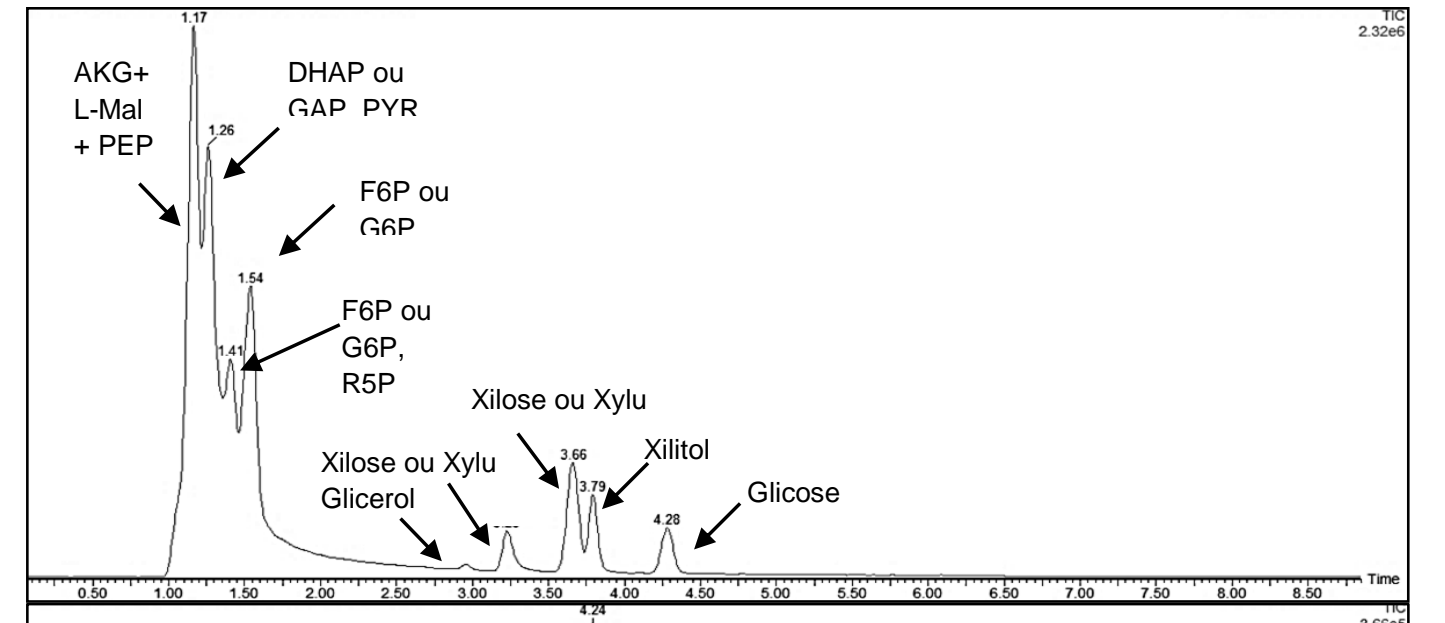

b)

c)

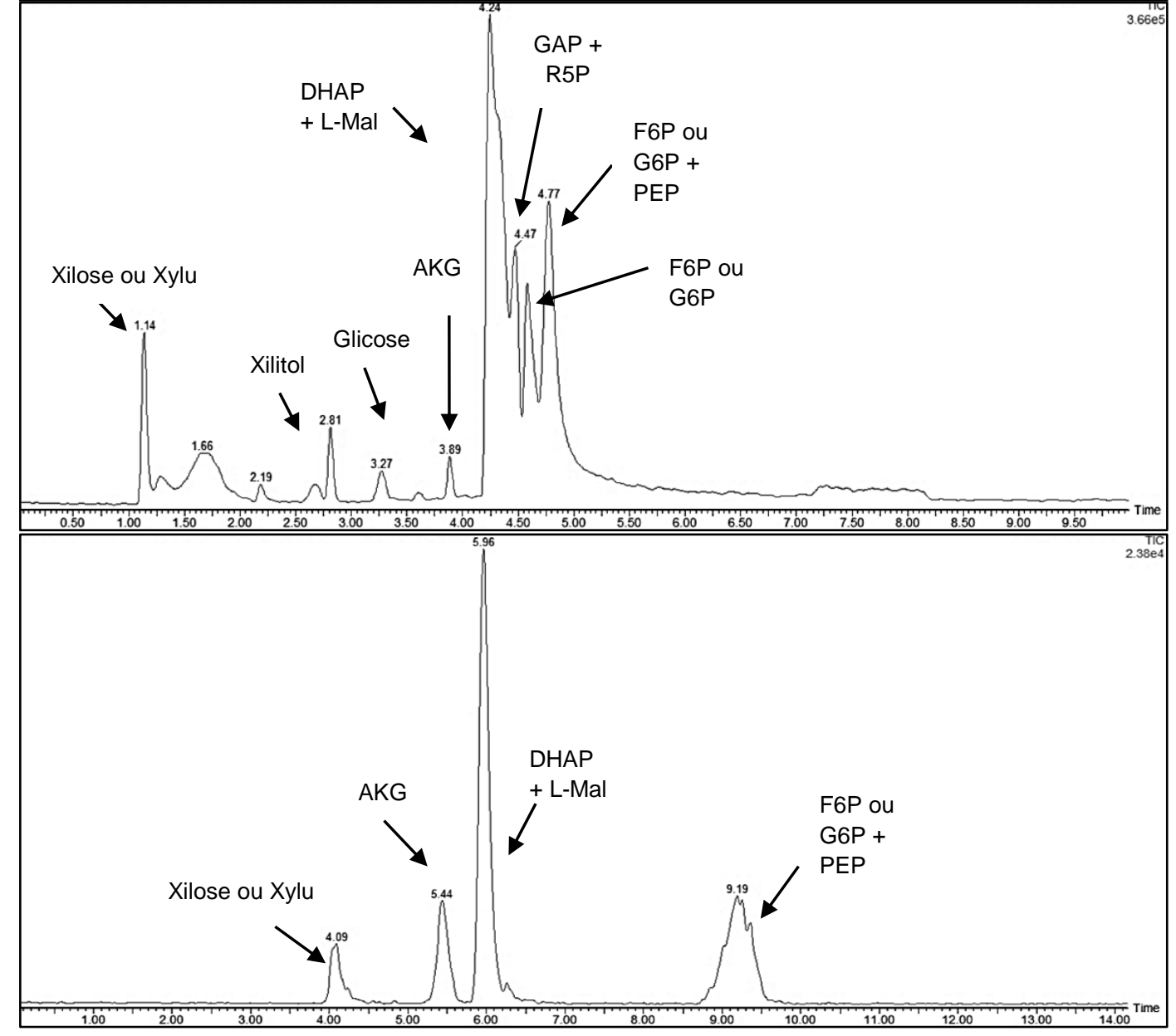

Figura 31. Cromatogramas da mistura de 14 padrões de metabólitos: a) FM: A: $\mathrm{NH}_{4} \mathrm{OH}$ 0,1\% B: ACN $+\mathrm{NH}_{4} \mathrm{OH} 0,1 \%$. b) FM: A: ACN:H $\mathrm{H}_{2} \mathrm{O}(50: 50)+\mathrm{AcNH}_{4}$ 10 mM B: $A C N: \mathrm{H}_{2} \mathrm{O}(90: 10)+\mathrm{AcNH} 4$ 10mM. c) FM: $\mathrm{A}: \mathrm{ACN}: \mathrm{H}_{2} \mathrm{O}(90: 10)+$ FormNH $5 \mathrm{mM}+\mathrm{NH}_{4} \mathrm{OH}$ 0.1\% B: $\mathrm{ACN}: \mathrm{H}_{2} \mathrm{O}(10: 90)+$ FormNH4 $5 \mathrm{mM}+$ $\mathrm{NH}_{4} \mathrm{OH} 0,1 \%$. 
Foram realizados testes com cinco padrões de diferentes classes químicas: frutose-6-fosfato, glicose-6-fosfato, ácido málico, xilulose e glicose. Estes padrões foram injetados individualmente em modo gradiente utilizando como composição de FM (A: Hidróxido de amônio 0,1\% e B: Acetonitrila + Hidróxido de amônio 0,1\%) (Figuras 32 e 33). Foi observado que as variações no gradiente e na temperatura, com o objetivo de melhorar a intensidade e 0 formato do pico para esses compostos, favoreceram apenas os padrões da glicose e da xilulose que apresentaram picos bem definidos e mais intensos (Figura $33 \mathrm{a}, \mathrm{b}$ ).

a)

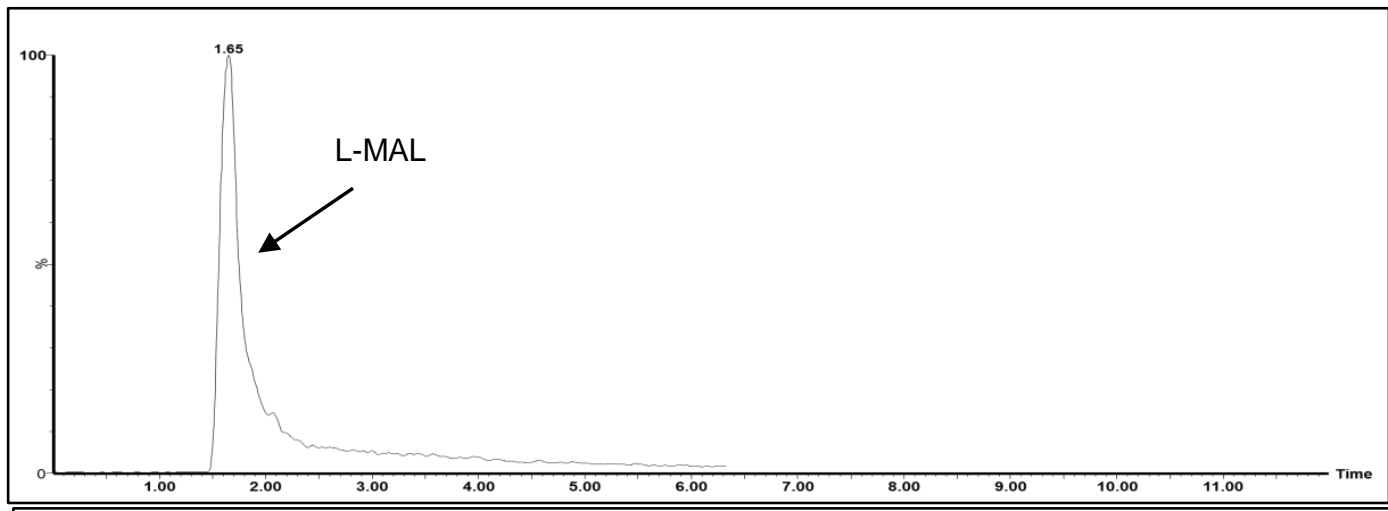

b)

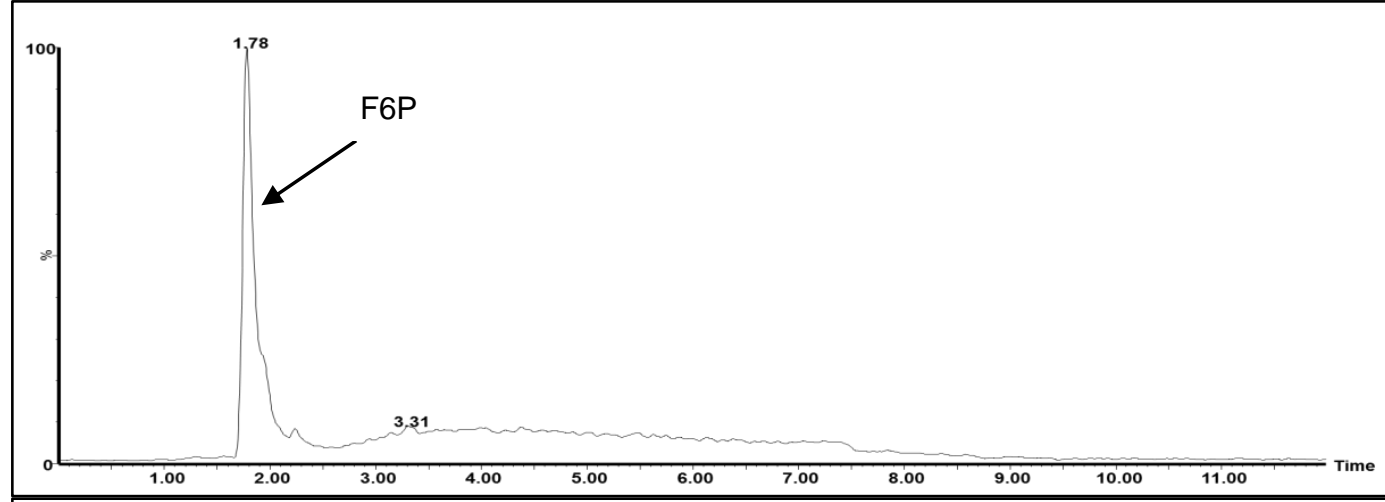

c)

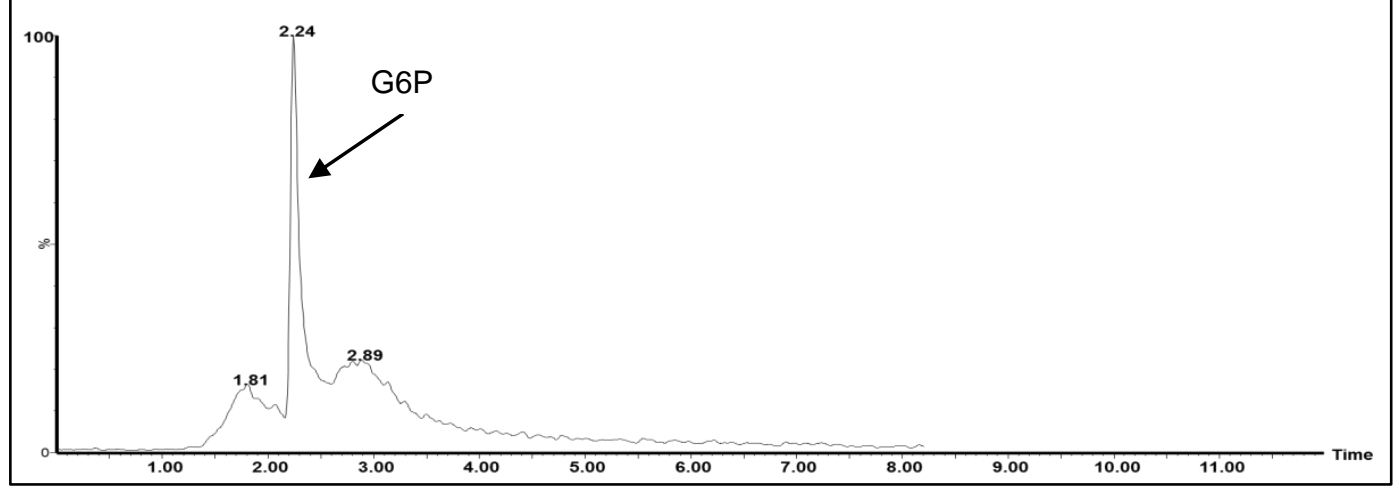

Figura 32. Cromatogramas de íons totais (TIC) dos padrões individuais: a) ácido málico - L-MAL; b) frutose-6-fostato - F6P; c) glicose-6-fosfato - G6P. 
a)

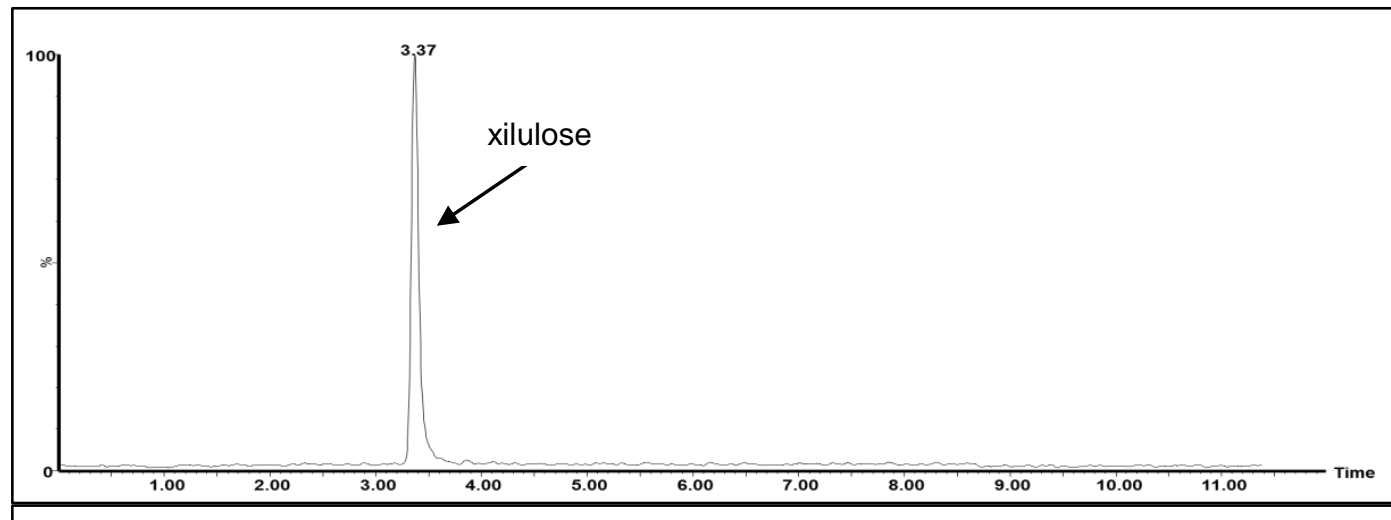

b)

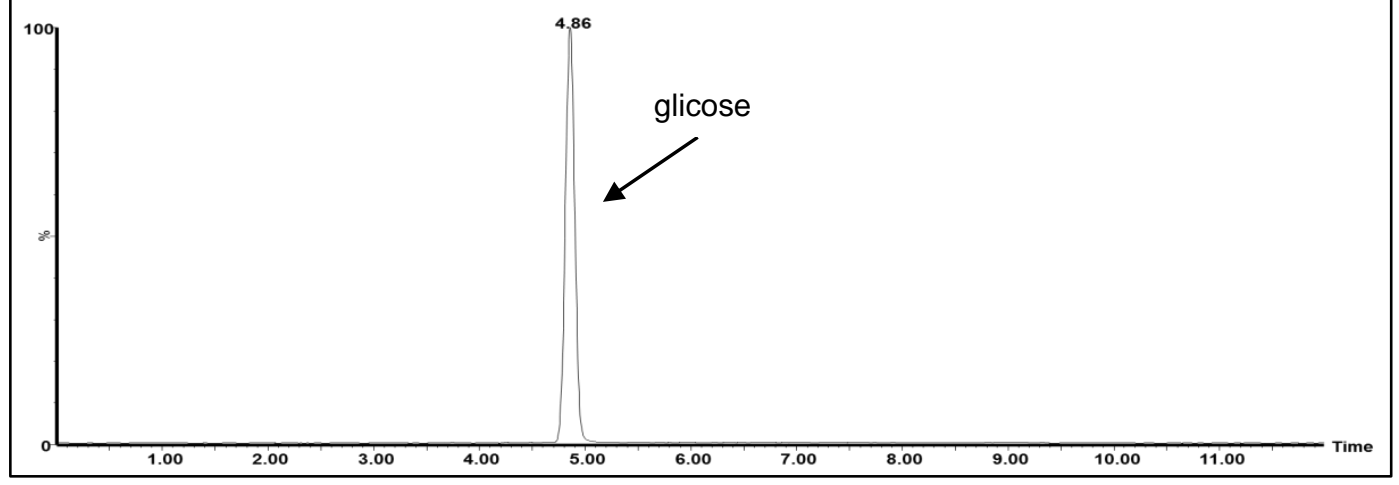

Figura 33. Cromatogramas de íons totais (TIC) dos padrões individuais: a) Xilulose e b) Glicose.

A partir destes resultados os compostos foram separados em dois grupos distintos de acordo com suas características químicas e modo de interação com a coluna cromatográfica. Um grupo foi formado pelos monossacarídeos, xilitol e glicerol e o outro grupo composto pelos ácidos orgânicos e os açúcares fosfatados. Desta forma foi desenvolvido um método utilizando a coluna BEH amida para separar cinco metabólitos neutros: xilose, xilulose, glicose, glicerol, e xilitol.

A Figura 34 apresenta o cromatograma da mistura dos cinco padrões de metabólitos a concentração de $50 \mu \mathrm{g} / \mathrm{mL}$, analisados pelo método HILIC otimizado. Diferentes tempos de retenção foram obtidos para os isômeros xilose e xilulose, confirmando a eficiência da separação que apresentou boa resolução cromatográfica com picos bem definidos. A identificação dos tempos de retenção dos isômeros foi realizada injetando esses compostos individualmente (Figura 35). 
a)

15_02) 23 3_Mix_grupo 2_R4 Sm (Mn, 3x3)
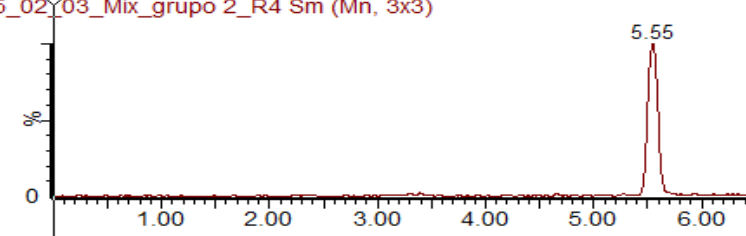

MRM of 5 Channels ES$179.1>58.9$ (Glicose)

b)

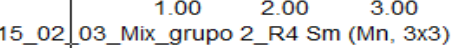

15_02_03_Mix_grupo 2_R4 Sm (Mn, 3x3)

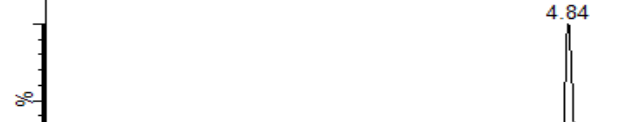

8.008 .00

$9.0010 .00 \quad 11.00$

MRM of 5 Channels ES-
$151>58.9$ (Xilitol) $151>58.9$ (Xilitol)
$2.38 \mathrm{e} 4$

c)
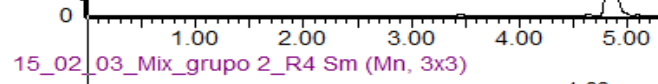

$6.00+7.00$

8.00

9.00

$10.00 \quad 11.00$

5_02 03 Mix grupo 2 R4 Sm (Mn, 3x3)

$149>59$ (D-xilulose)

xilulose xilose

d)
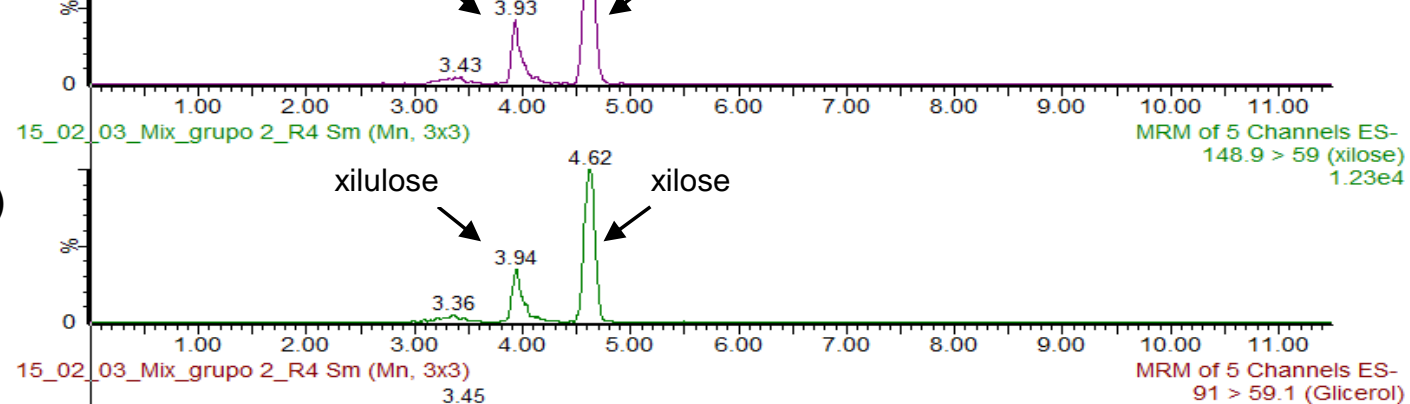

e)

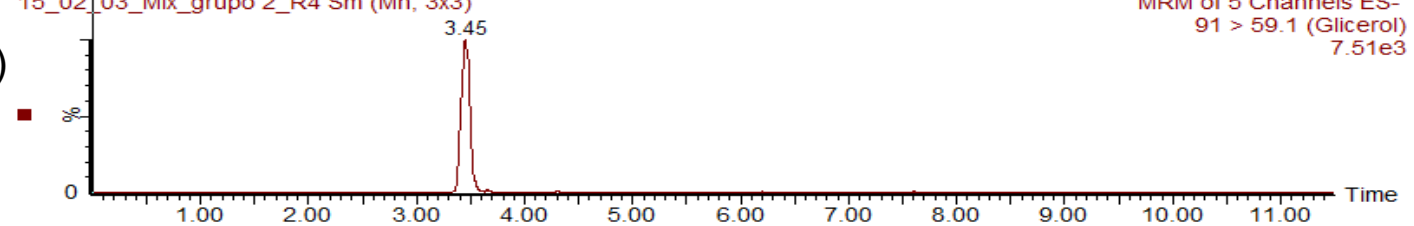

Figura 34. Cromatograma dos canais de MRM do método HILIC utilizando como FM (A: Hidróxido de amônio 0,1\% e B: Acetonitrila + Hidróxido de amônio 0,1\%) para a mistura de cinco padrões de metabólitos: a) glicose 179,1 >58,9, b) xilitol $151>58.9$, c) xilulose $149>59$, d) xilose 148,9 > 59, e) glicerol $91>$ 59,1 . 
a)

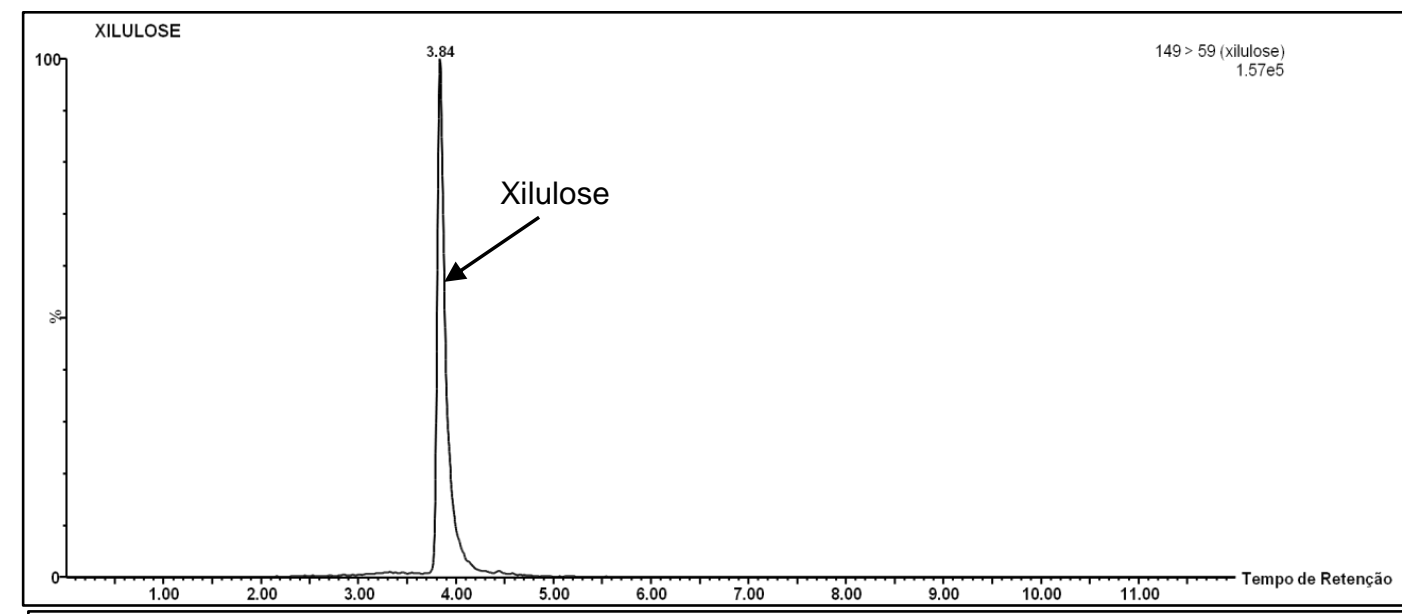

b)

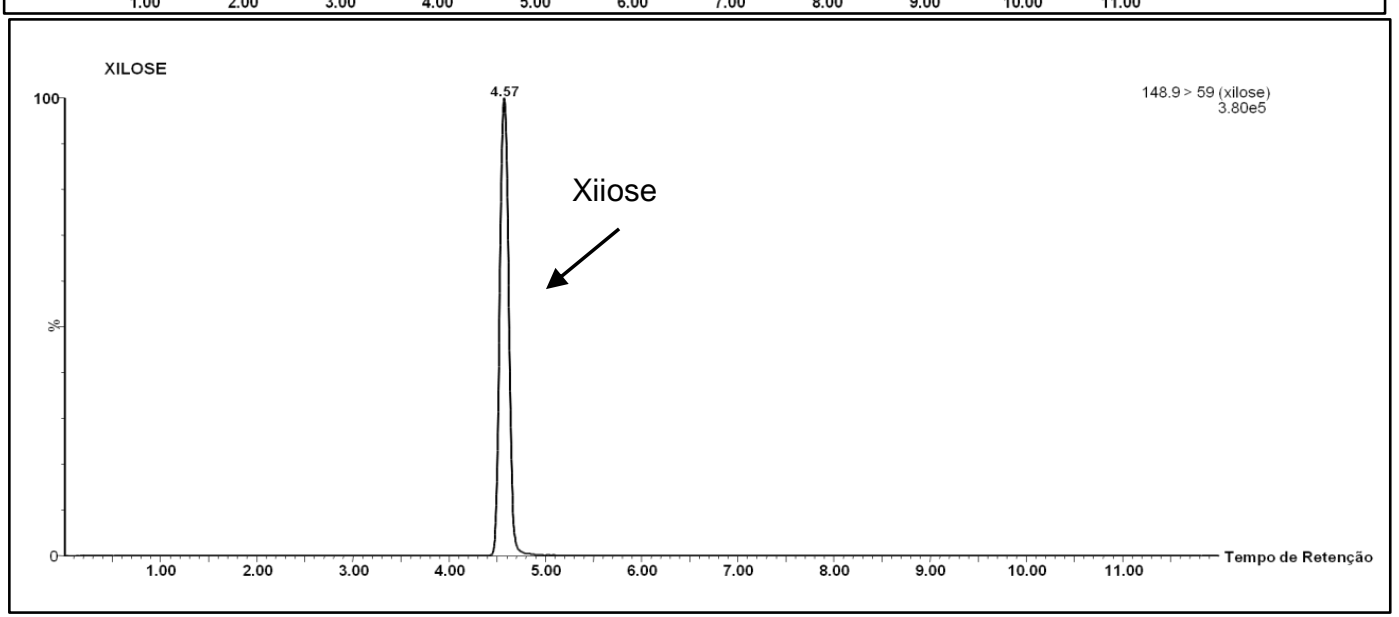

Figura 35. Cromatograma de íons totais (TIC) do método HILIC utilizando como FM (A: Hidróxido de amônio 0,1\% e B: Acetonitrila + Hidróxido de amônio $0,1 \%$ ) dos compostos: a) xilulose e b) xilose.

\subsubsection{Cromatografia por Pareamento lônico (IPC- ion pair chromatography)}

A cromatografia por pareamento iônico basea-se na separação de espécies facilmente ionizáveis em colunas de fase reversa. Em geral utiliza-se alquil aminas voláteis como reagente de pareamento iônico, que juntamente com um ácido orgânico compõe a fase aquosa. Utiliza-se um composto polar como modificador orgânico, como o metanol ou propan-2-ol. O íon par reagente interage com a fase estacionária, deixando-a carregada com a carga oposta do 
analito de interesse, aumentando significativamente o tempo de retenção e a seletividade da coluna de fase reversa.

A coluna HSS-T3 (Waters) foi utilizada no desenvolvimento do método por pareamento iônico. Foram testados dois reagentes para a formação do par iônico, a trietilamina (TEA) e a tributilamina (TBA), em diferentes composições de fases móvel, pH e temperatura da coluna, em modo isocrático e gradiente.

Luo et $a l^{64}$ testaram diferentes tipos de alquil aminas, como reagentes de par iônico, para a separação de metabólitos como os açúcares fosfato e ácidos orgânicos e observaram que o tamanho da cadeia alquil está diretamente relacionado com o tempo de eluição do analito. Entre todas as alquilaminas investigadas a tributilamina apresentou melhor retenção dos compostos, aliado a sensibilidade e uma boa resolução dos picos cromatográficos.

A Figura 36 apresenta as estruturas das duas alquil aminas testadas neste método. A TBA possui um grupo alquil maior que a TEA e este fato implica no aumento do caráter hidrofóbico da molécula, e consequentemente em uma maior interação com a coluna. O mecanismo de interação do modo de separação IPC é apropriado para análise de pentoses e hexoses fosfatadas e ácida orgânicos, desta forma nove padrões foram avaliados a partir deste método, sendo eles: AKG, DHAP, F6P, G6P, GAP, R5P, L-MAL, PEP, PYR.

(a) Trietilamina

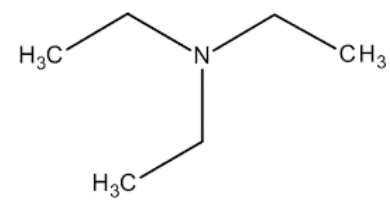

(b) Tributilamina

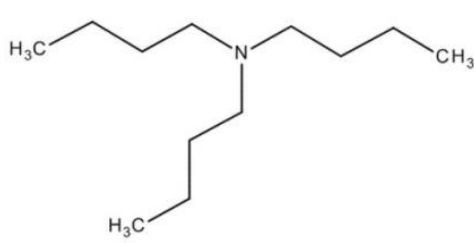

Figura 36. Estrutura das moléculas dos reagentes do par iônico. a) Trietilamina (TEA), b) Tributilamina (TBA).

Inicialmente foi utilizado como fase móvel, uma solução de trietilamina $5 \mathrm{mM}$ e ácido fórmico $10 \mathrm{mM}$ (Figura 37 a,b, respectivamente). No entanto os padrões não ficaram retidos na coluna e foram eluídos no início da análise 
cromatográfica. A concentração de TEA foi aumentada para $10 \mathrm{mM}$, a fim de melhorar a separação. Os resultados obtidos com o uso da TEA $10 \mathrm{mM}$ também não foram satisfatórios. $O$ aumento da concentração resultou em uma melhora pouco significativa na resolução dos picos cromatrográficos, mas mesmo assim os compostos foram eluídos rapidamente, não havendo uma separação satisfatória dos metabólitos testados. Desta forma o uso da trietilamina (TEA) foi abandonado neste estudo, e os testes passaram a ser realizados com a tributilamina (TBA).

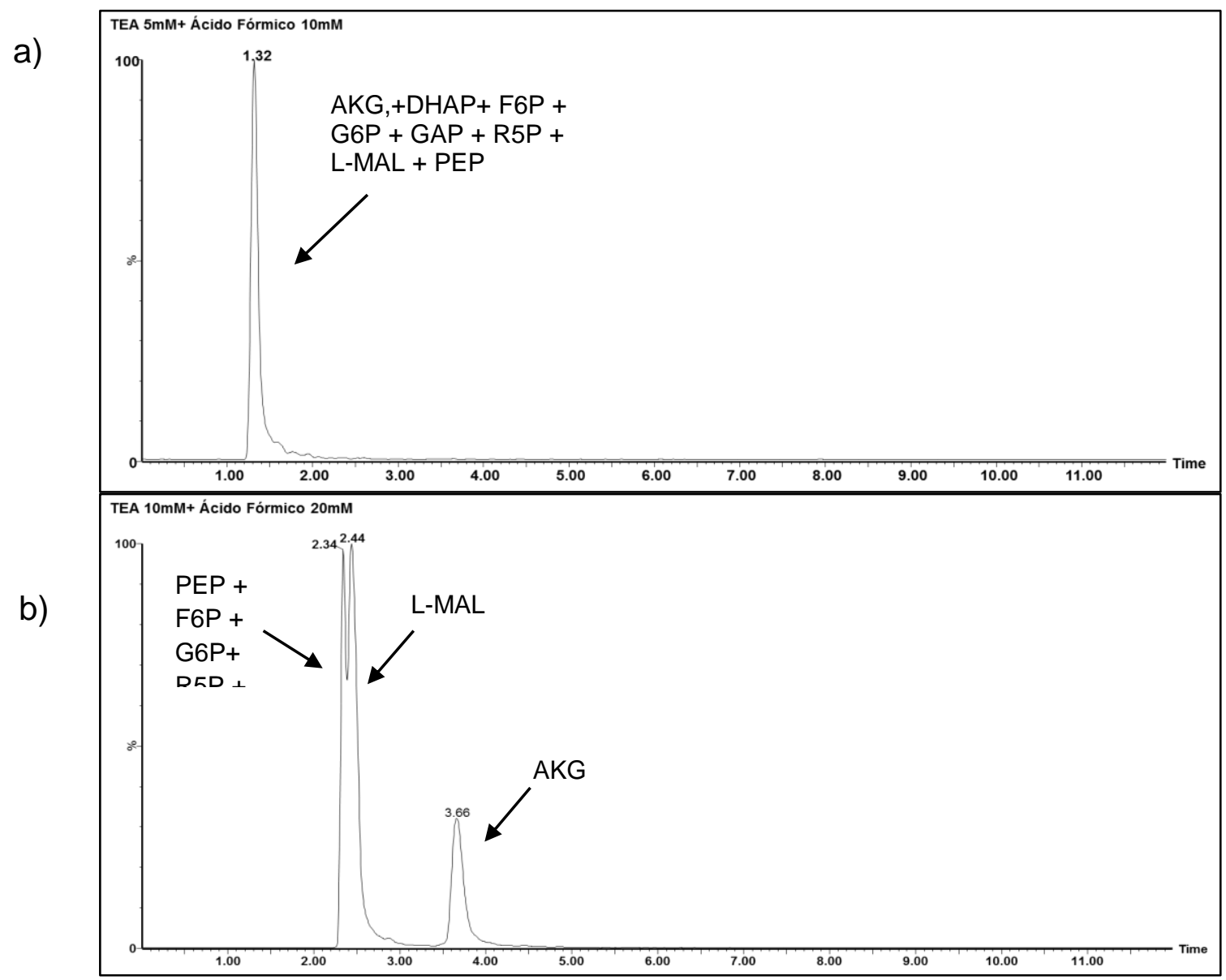

Figura 37. Cromatograma da mistura de oito padrões de metabólitos: (a) Trietilamina $5 \mathrm{mM}$ + ácido fórmico $20 \mathrm{mM}$, (b) Trietilamina $10 \mathrm{mM}$ + ácido fórmico $20 \mathrm{mM}$. 
Os resultados encontrados com o uso da tributilamina como reagente de par iônico, são coerentes com os encontrados na literatura. De fato, bons resultados foram conseguidos principalmente em relação aos compostos fosfatados. Foram testados metanol e acetonitrila como eluente orgânico no método cromatográfico (Figura 38), sendo que o metanol (Figura 38a) apresentou melhor resultado de separação quando comparado a acetonitrila (Figura 38b), principalmente em relação aos compostos: AKG e L-MAL, DHAP e GAP.

a)

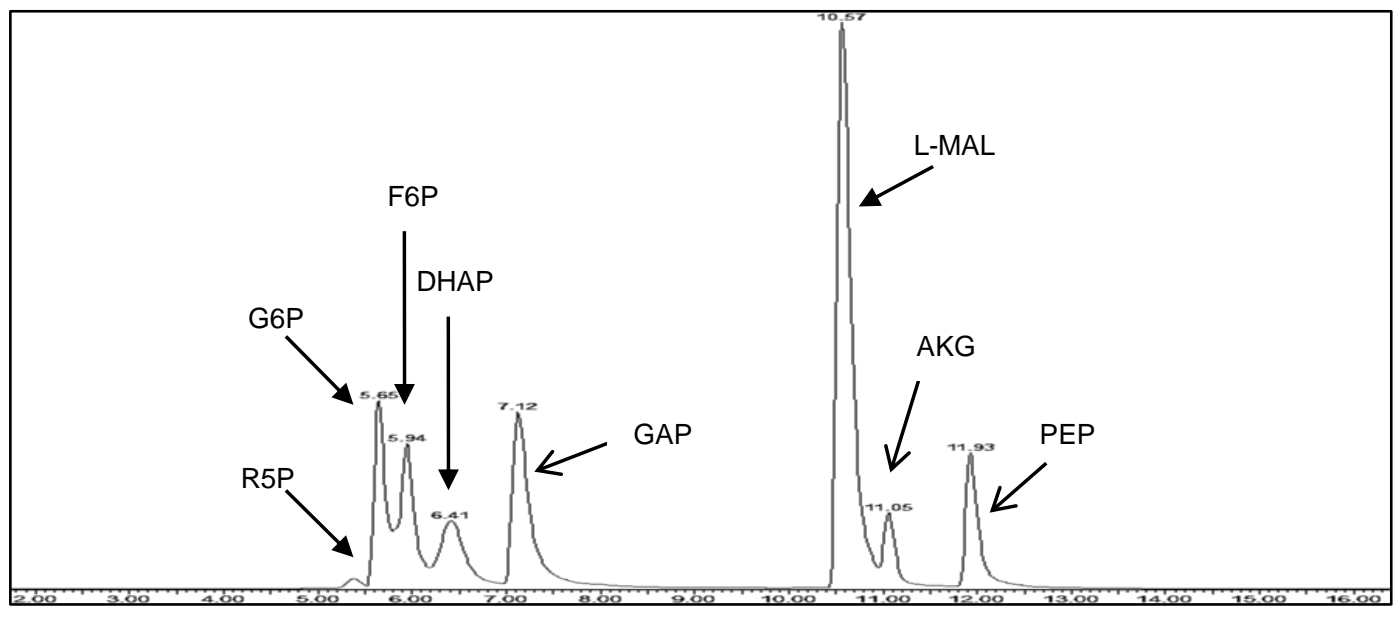

b)

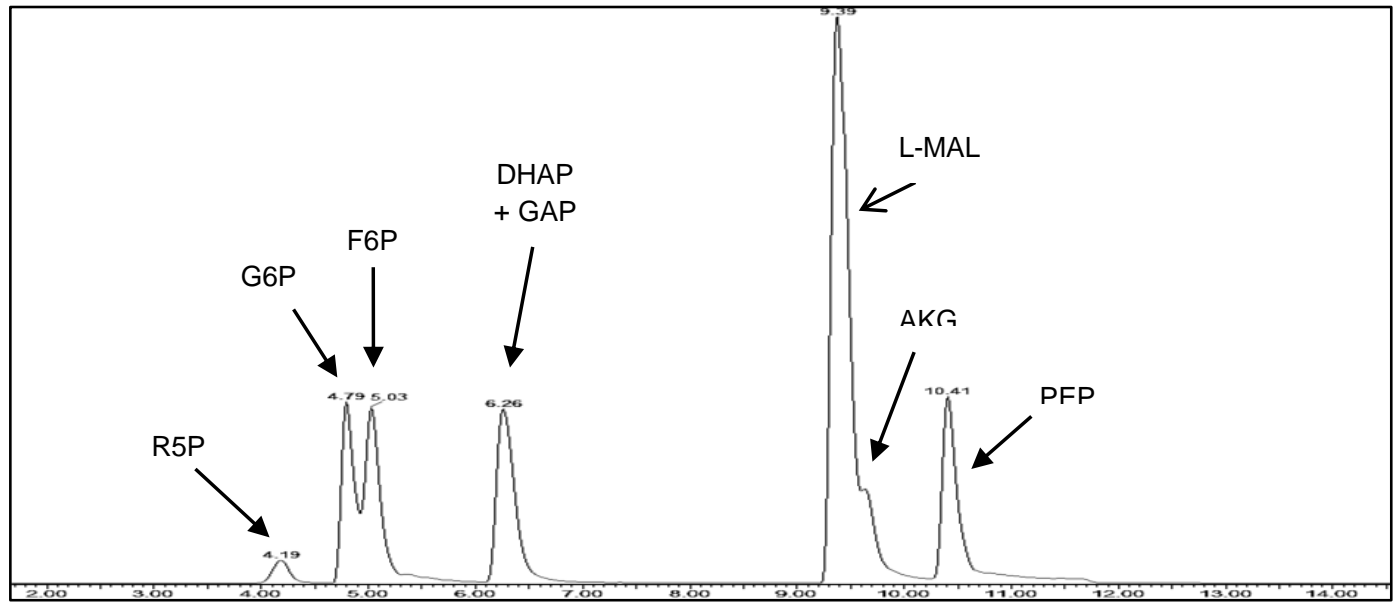

Figura 38. Cromatogramas dos íons totais (TIC) da mistura de oito padrões de metabólitos por ESI(-)-MS/MS no modo MRM: A: TBA 2 mM + Ácido Acético 4 mM, B: (a) Metanol (b) Acetonitrila (o eixo horizontal é o tempo de retenção em minutos). 
Foram testados os modos isocrático (Figura 39a) e gradiente (Figura 39b) da FM A: TBA $2 \mathrm{mM}$ + Ácido Acético 4 mM, B: Metanol, e constatou-se uma melhor separação dos picos cromatográficos utilizando o modo gradiente.

a)

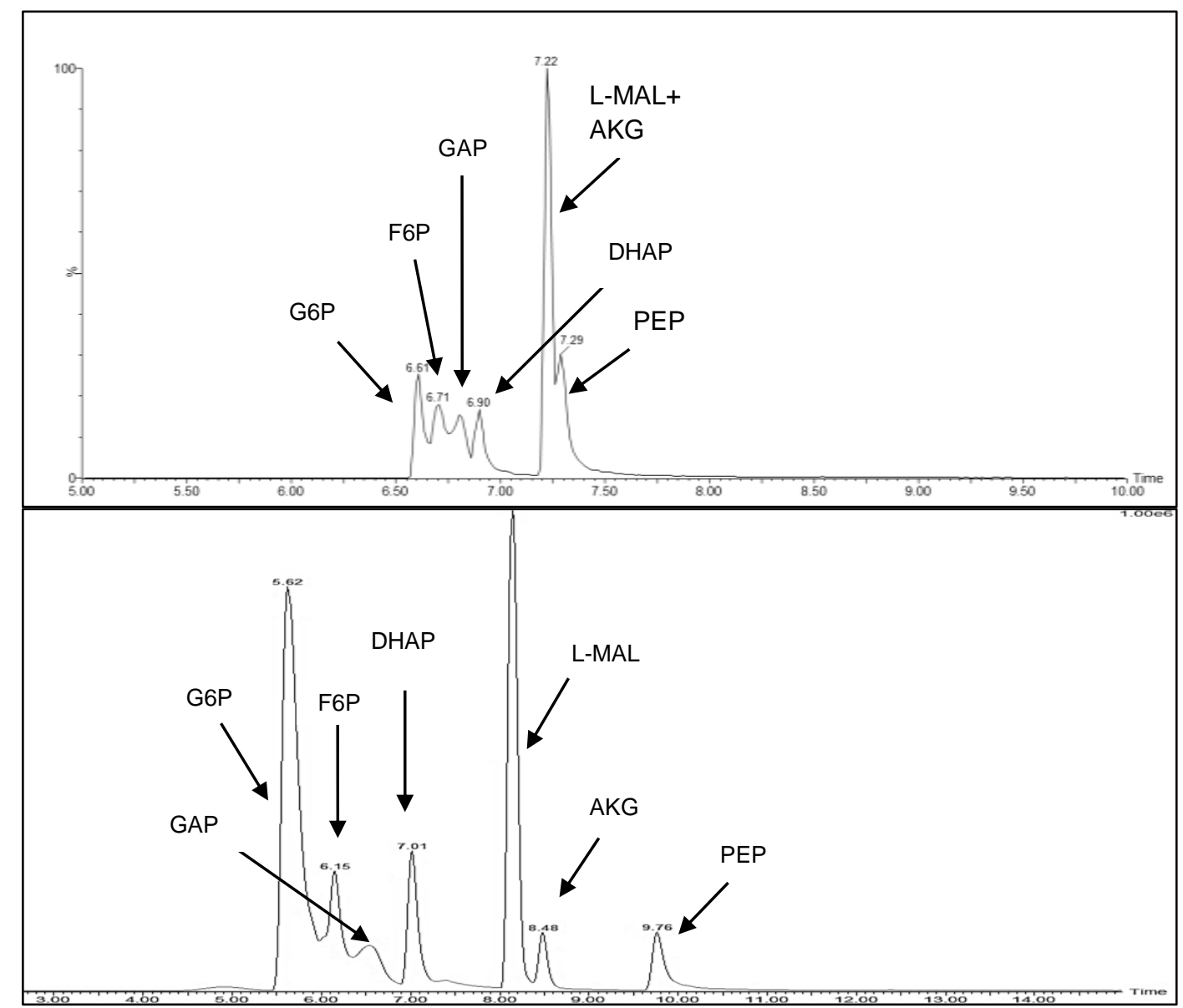

Figura 39. Cromatogramas de íons totais (TIC) da mistura de oito padrões de metabólitos FM: TBA $2 \mathrm{mM}$ + Ácido Acético $4 \mathrm{mM}$, nos modos: (a) Isocrático, (b) Gradiente. (eixo horizontal é o tempo de retenção em minutos).

A influência da variação do $\mathrm{pH}$ no método cromatográfico foi testada utilizando três soluções aquosas de TBA contendo $3 \mathrm{mM}$ de ácido acético, $\mathrm{pH}=5.1$ (Figura 40a), $4 \mathrm{mM}$ de ácido acético, $\mathrm{pH}=4.8$ (Figura 40b) e $5 \mathrm{mM}$ de acetato de amônio, $\mathrm{pH}=6,2$ (Figura 40c). A separação dos açúcares fosfatados sofreu pouca influência para diferentes valores de $\mathrm{pH}$. Apenas o composto ribose-5-fosfato apresentou alteração significante. Os compostos contendo 
grupos carboxílicos sofreram alteração no perfil cromatográfico mesmo para uma pequena variação do $\mathrm{pH}$. A fase móvel com $\mathrm{pH}=4.8$ (Figura 40b), mostrou ser a mais apropriado para a separação dos metabólitos.

a)

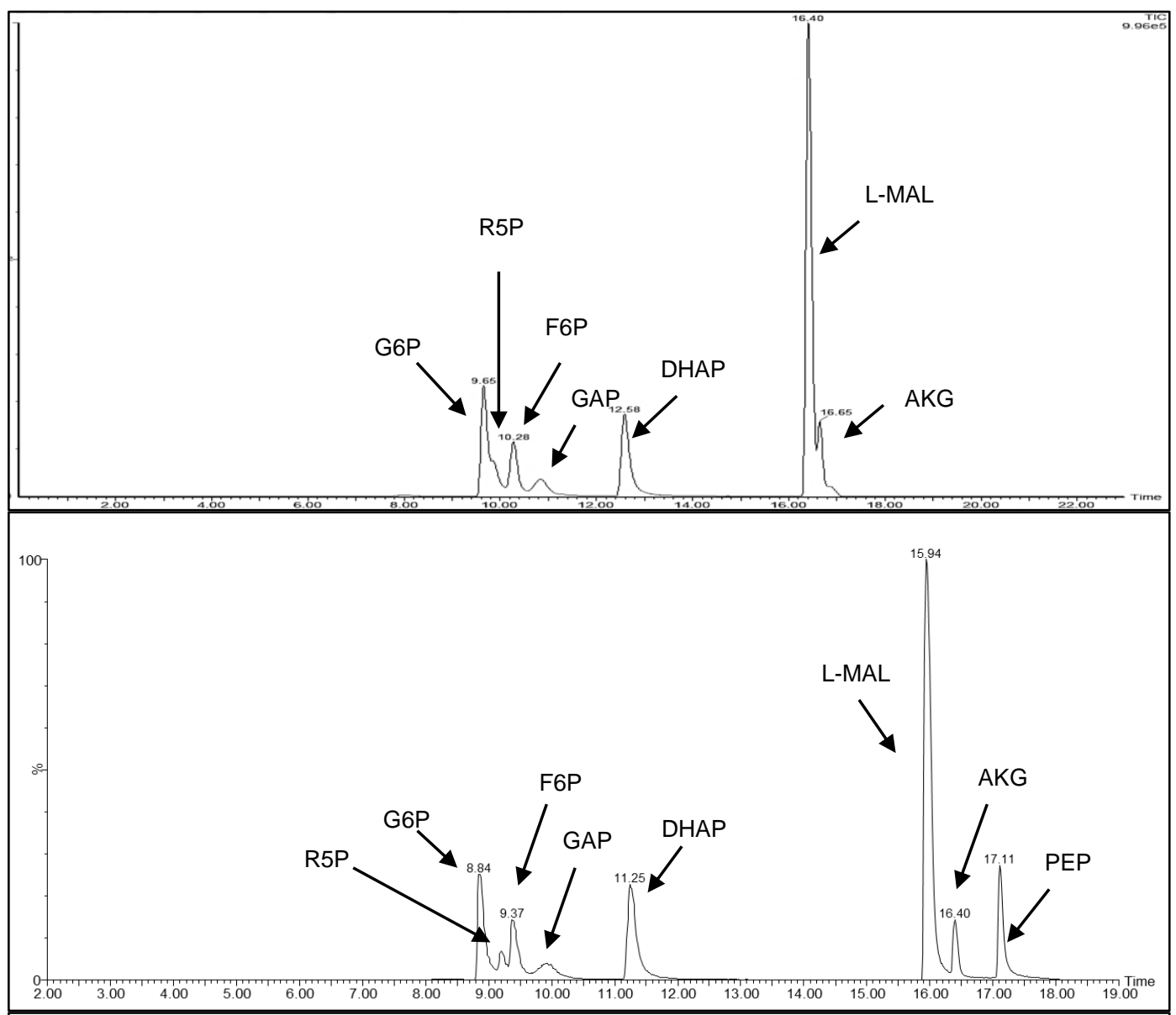

c)

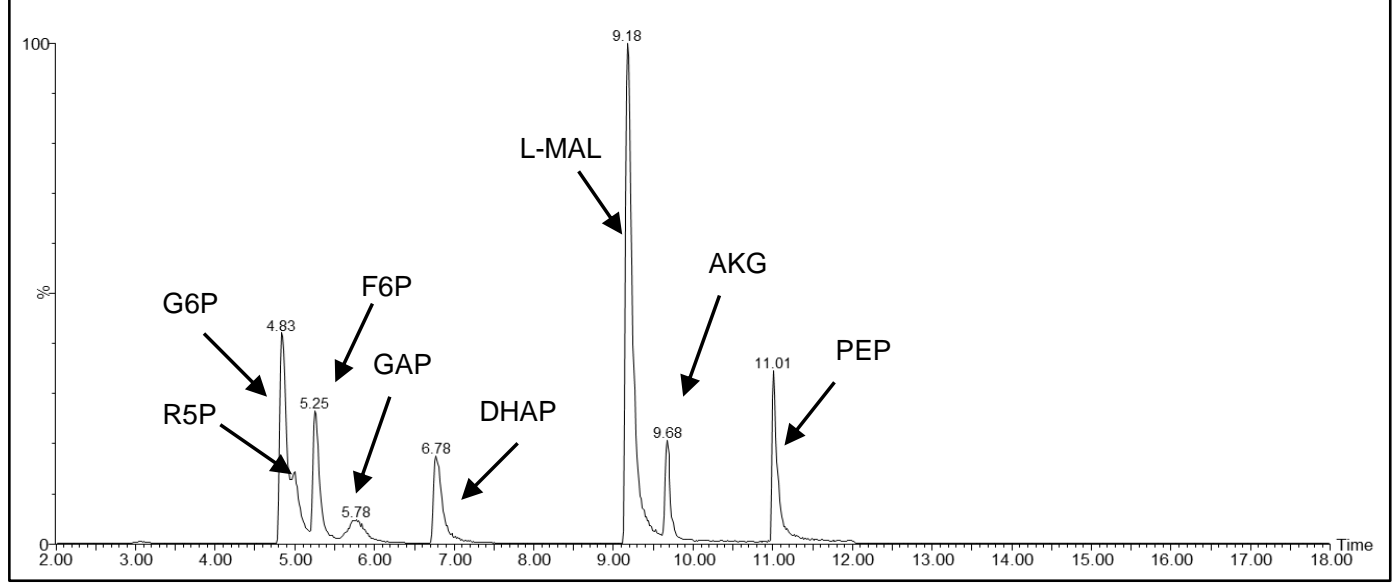

Figura 40. Cromatogramas de íons totais (TIC) da mistura de oito padrões de metabólitos: (a) fase móvel: TBA $2 \mathrm{mM}+$ Ácido Acético $3 \mathrm{mM}, \mathrm{pH}=5.1$ (b) fase móvel: TBA $2 \mathrm{mM}+$ Ácido Acético $4 \mathrm{mM}, \mathrm{pH}=4.8$ (c) fase móvel: TBA $2 \mathrm{mM}+$ Acetato de Amônio $5 \mathrm{mM}, \mathrm{pH}=6,2$. 
O aumento na concentração do reagente formador do pareamento iônico está diretamente relacionado com a capacidade de retenção. Na Figura 41 são apresentados os cromatogramas da mistura de padrões utilizando três diferentes concentrações de tributilamina: $2 \mathrm{mM}$ (Figura 41a), $5 \mathrm{mM}$ (Figura 41b) e 10 mM (Figura 41c). O cromatograma que apresentou melhor separação cromatográfica, principalmente em relação aos isômeros contendo o grupo fosfato, foi adquirido com a utilização de $10 \mathrm{mM}$ de tributilamina. No entanto a desvantagem do método IPC está na contaminação do reagente do pareamento iônico, a tributilamina, no espectrômetro de massas. As análises não podem ser realizadas utilizando o modo positivo, pois a molécula de TBA ioniza gerando um sinal muito intenso $(\mathrm{m} / \mathrm{z} 186)$ referente ao seu íon precursor.

Desta forma, a fim de preservar o equipamento a fase móvel do método otimizado na cromatografia IPC consistiu na utilização da menor concentração de tributilamina possível, FM: (A) $5 \mathrm{mM}$ TBA + $10 \mathrm{mM}$ Ácido Acético $+5 \% \mathrm{MeOH}$ (B) Metanol. (Figura 41b). 


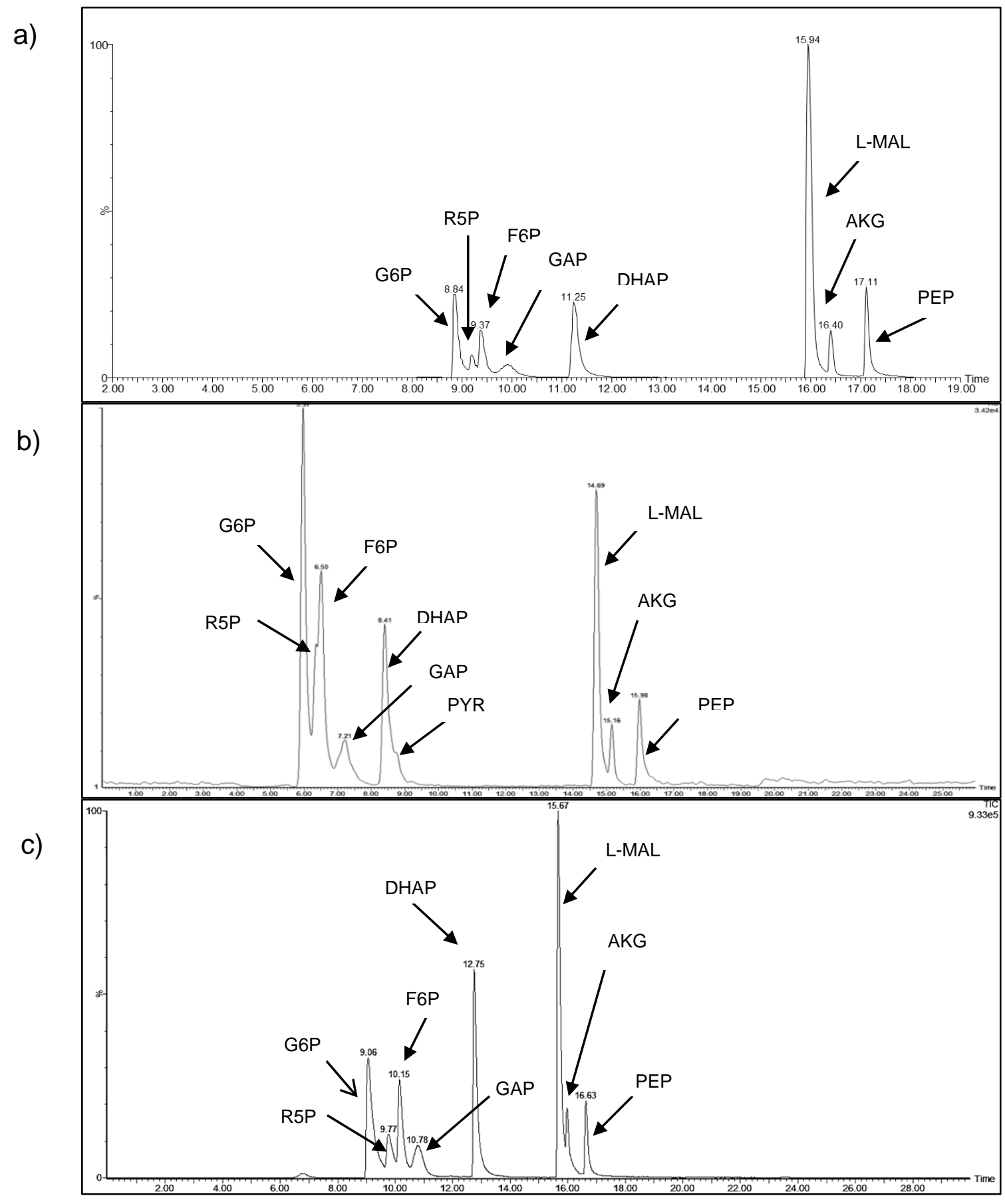

Figura 41. Cromatogramas de íons totais (TIC) (a) fase móvel: TBA $2 \mathrm{mM}+$ Ácido Acético $4 \mathrm{mM}+5 \% \mathrm{MeOH}$ (b) fase móvel: TBA $5 \mathrm{mM}+$ Ácido Acético 10 mM (c) fase móvel: TBA 10mM + Ácido Acético 15 mM. 


\subsubsection{Cromatografia por troca iônica (IEC - Ion Exchange chromatography)}

Com o intuito de definir um método capaz de separar todos os metabólitos em uma mesma corrida, o método IEC foi testado utilizando a coluna aminex (Bio-Rad). Embora fabricada para o uso em HPLC, esta coluna foi adaptada para o desenvolvimento do método por UHPLC-MS. Os protocolos de análise desta coluna sugerem o uso de uma solução aquosa de ácido sulfúrico como fase móvel, tendo em vista que o a faixa de trabalho desta coluna varia de 1 a 3 unidades de $\mathrm{pH}$. No entanto o ácido sulfúrico não é indicado para o uso no espectrômetro de massas, desta forma dois outros ácidos foram testados como fase móvel, o ácido trifluoro acético e o ácido fórmico.

A utilização de ambos os ácidos foram comparados (Figura 42 a, b) e os cromatogramas apresentados indicam baixa seletividade tanto para o ácido fórmico quanto para o ácido trifluoro acético. As condições cromatrográficas testadas, temperatura ambiente e um fluxo isocrático de $0,6 \mathrm{~mL} / \mathrm{min}$, não foram capazes de separar os padrões de metabólitos analisados. Em ambos os casos os compostos com o grupo fosfato e o fosfoenolpiruvato foram co-eluídos primeiro. Na Figura $42 a$ os monossacarídios xilose, xilulose, e glicose, não foram detectados, assim como os compostos PYR, glicerol e xilitol. Os picos com melhores resoluções para ambos os eluentes foram do ácido málico e do ácido alfacetoglutárico, no entanto a utilização do ácido fórmico apresentou picos com maior área e intensidade para estes dois compostos, por isso foi escolhido como FM para a realização de outros testes. 
a)

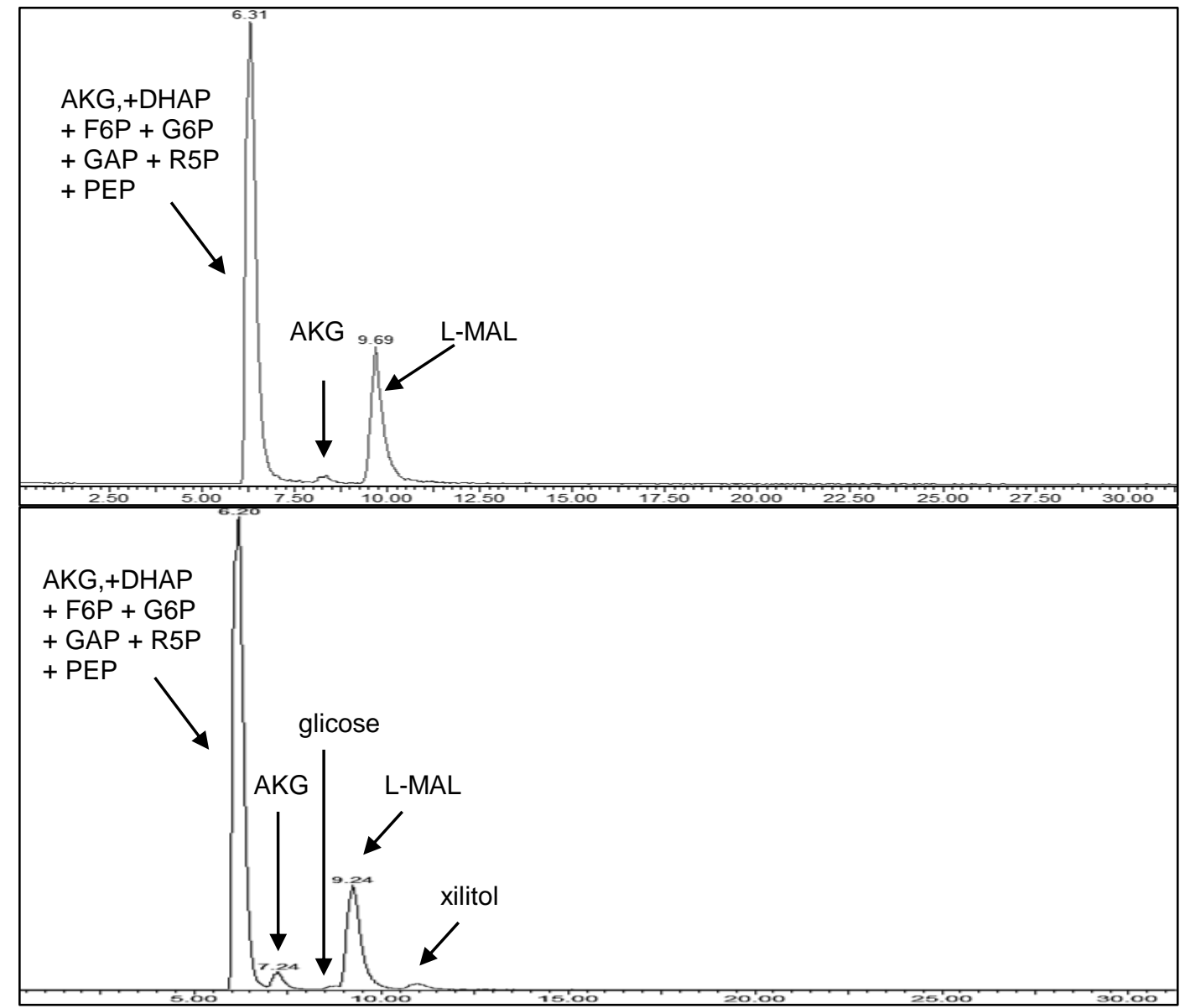

Figura 42. Cromatogramas de íons totais (TIC) da mistura de catorze padrões de metabólitos em modo isocrático, à temperatura ambiente: (a) Ácido Trifluoroacético 0,05\%, (b) Ácido fórmico 0,1\%.

Foram testados dois sistemas isocráticos com a solução de ácido fórmico $0,1 \%$. A figura 43 a apresenta um sistema isocrático, composto por $90 \%$ de $\mathrm{A}$ (ácido fórmico $0,1 \%$ ) e $10 \%$ de $\mathrm{B}$ (acetonitrila) à temperatura ambiente $\mathrm{e}$ vazão de $0,5 \mathrm{~mL} / \mathrm{min}$. A figura 43b corresponde a um sistema isocrático com $100 \%$ de ácido fórmico 0,1\%, a temperatura ambiente e fluxo de 0,6 mL/min. 0 uso da acetonitrila afetou apenas o tempo de retenção dos analitos. Com a ausência da acetonitrila os açúcares fosfatados, por exemplo, passaram a ser eluídos em um tempo de retenção menor, de 7.1 minutos (Figura 43a) para 6.19 minutos (Figura 43b). No entanto, as alterações realizadas não 
melhoraram a separação dos catorze padrões testados, tendo o perfil cromatográfico permanecido inalterado.

a)

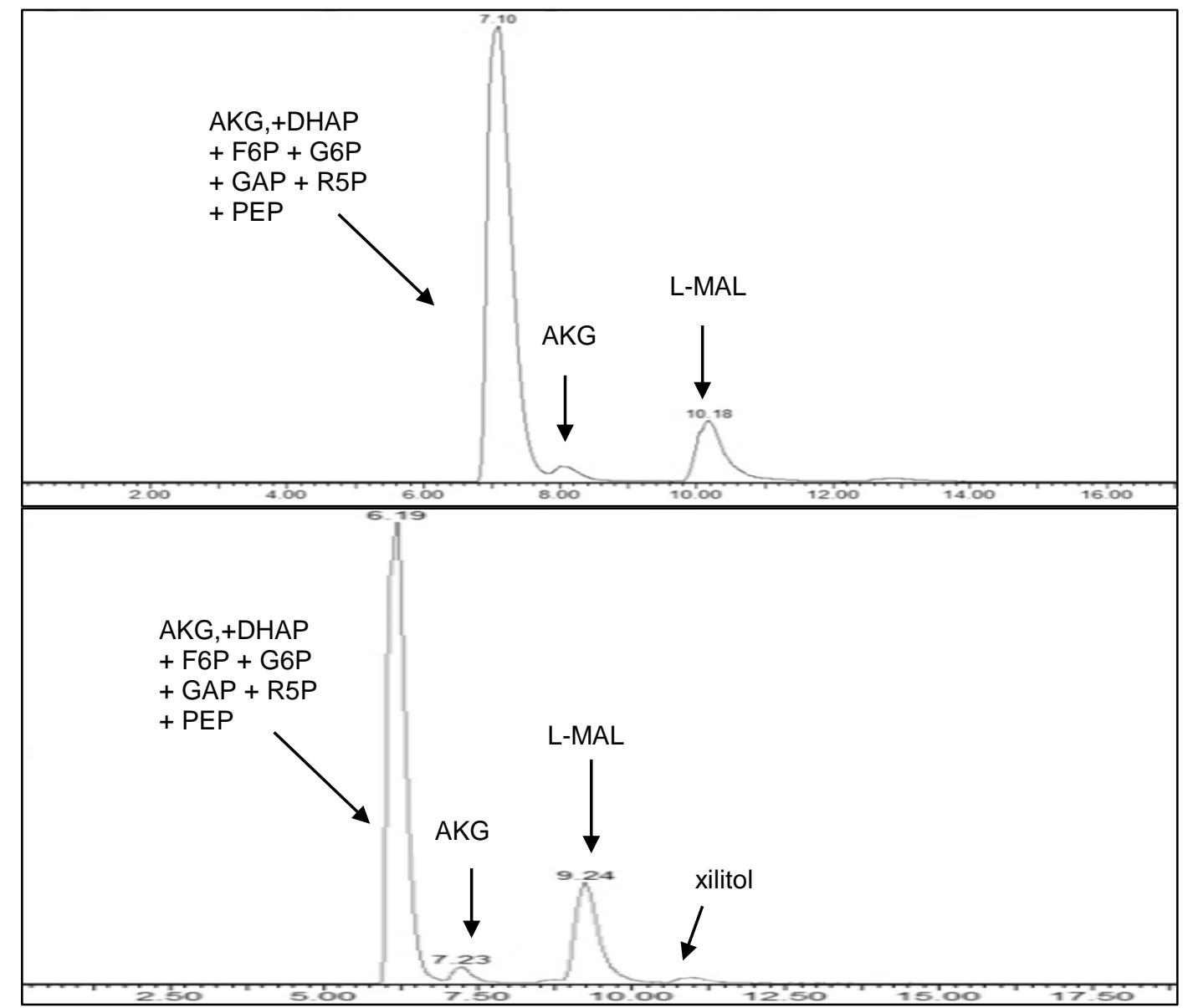

Figura 43. Cromatogramas de íons totais (TIC) da mistura de catorze padrões de metabólitos, à temperatura ambiente. (a) A: $90 \%$ de ácido fórmico $0,1 \%, B$ : $10 \%$ de acetonitrila (b) $100 \%$ de ácido fórmico $0,1 \%$.

Os experimentos com a coluna aminex não foram promissores para os compostos: glicose, xilose, xilulose, xilitol, glicerol e piruvato, por isso foi preparada uma mistura a uma concentração de $50 \mu \mathrm{g} / \mathrm{mL}$ contendo os ácidos orgânicos, e as pentoses e hexoses fosfatos, totalizando oito compostos. Este grupo foi analisado com ácido fórmico $0,1 \%$ como eluente em modo isocrático, em duas temperaturas: $45^{\circ} \mathrm{C}$ (Figura $44 \mathrm{a}$ ) e $65^{\circ} \mathrm{C}$ (Figura 44b). A variação na temperatura ocasionou uma leve diminuição nos tempos de retenção (eixo 
horizontal em minutos) dos ácidos orgânicos e uma melhora na intensidade do sinal dos padrões. $\mathrm{O}$ ácido málico e o ácido alfacetoglutárico puderam ser identificados neste método mais os outros seis compostos não foram separados (pico 1 da Figura 44 a e b). Sendo assim está técnica não é indicada para a análise dos metabólitos presentes nas vias metabólicas de fermentação de xilose em leveduras.

O insucesso do método de separação por cromatografia de troca iônica pode ser atribuído às características físicas da coluna aminex. A diminuição do tamanho de partícula da coluna está relacionada ao aumento da sua eficiência. Desta forma, as colunas com as quais se obteve boa separação cromatográfica no desenvolvimento dos métodos otimizados, possuem tamanho de partículas menores quando comparados à coluna aminex.

a)

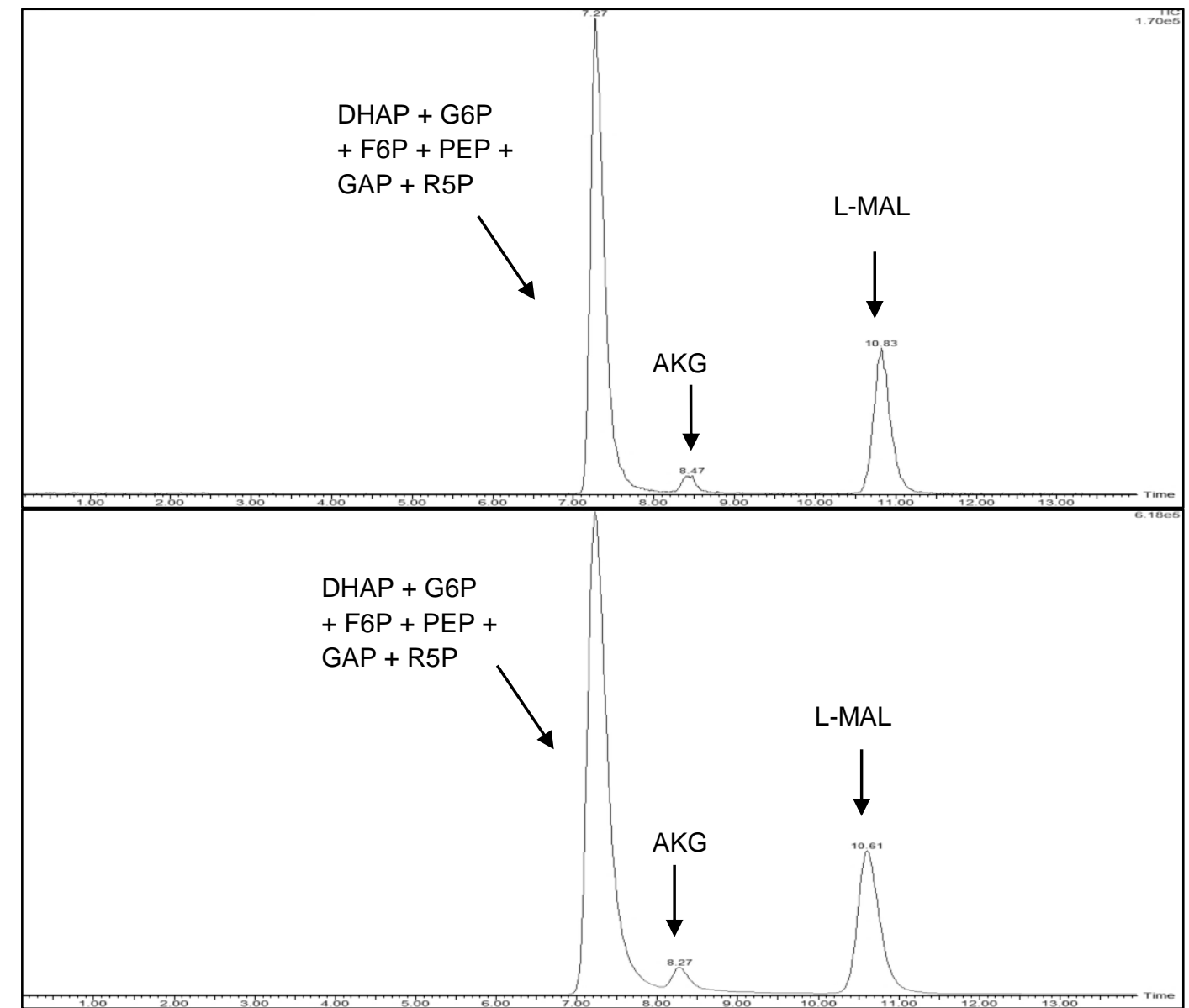

Figura 44. Cromatogramas de íons totais (TIC) da mistura de oito padrões de metabólitos em modo isocrático, $\mathrm{FM}$ ácido fórmico $0,1 \%$. (a) $45^{\circ} \mathrm{C}$ (b) $65^{\circ} \mathrm{C}$. 


\subsection{Análises das Amostras Biológicas por UHPLC- MS/MS}

Os padrões utilizados na otimização dos métodos por UHPLC-MS/MS estão indicados na Figura 45. Desta forma, é possível notar que os metabólitos presentes em grande parte da via fermentativa podem ser detectados. Após a etapa de desenvolvimento de métodos analíticos, os dois métodos cromatográficos, HILIC e IPC, que apresentaram os melhores resultados, foram utilizados para a análise por UHPLC-MS/MS dos metabólitos produzidos por duas espécies de leveduras fermentadoras de xilose: Scheffersomyces stipitis e Spathaspora passalidarum.

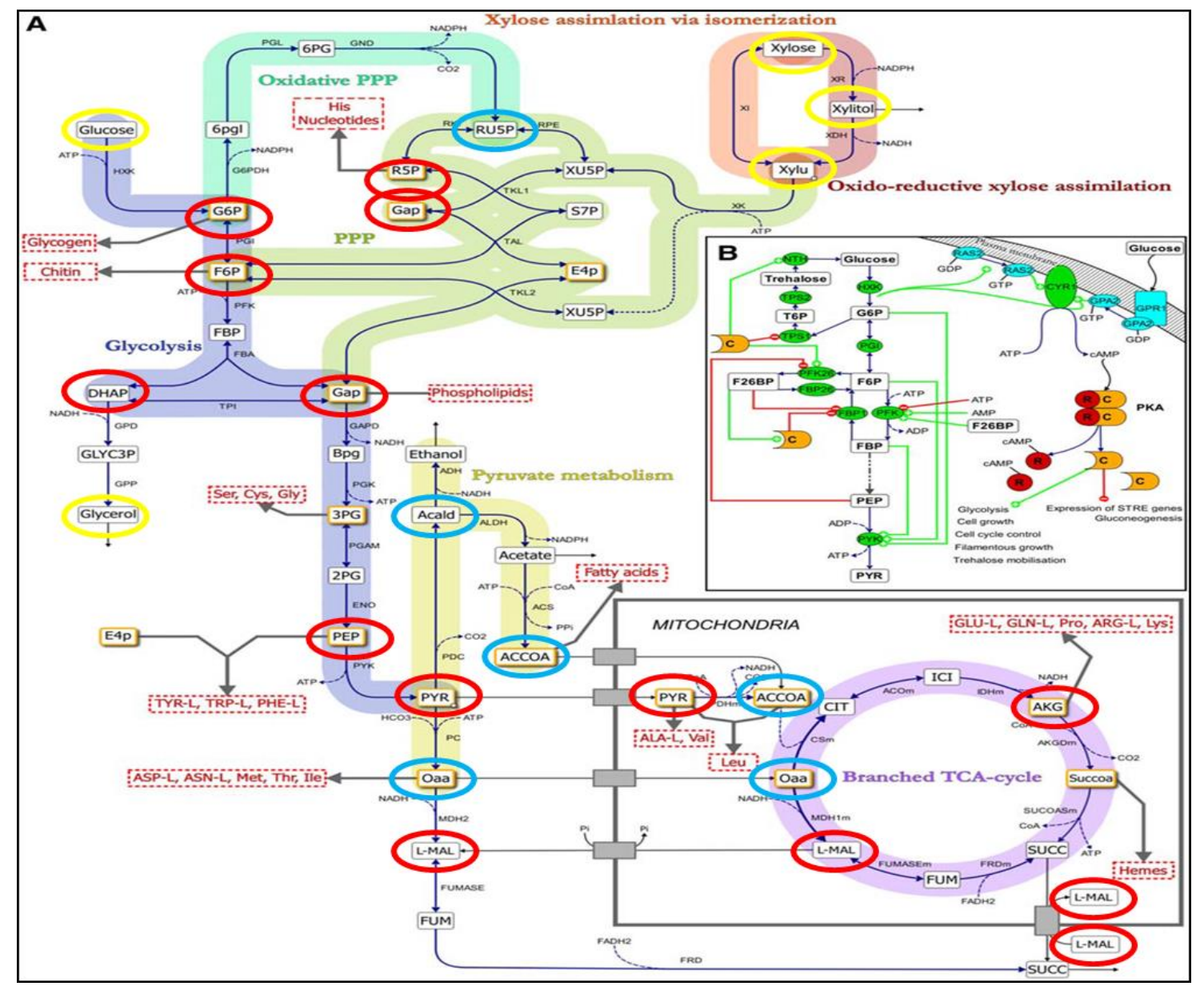

Figura 45 Visão geral das principais reações metabólicas no metabolismo do carbono central. Padrões circulados na cor vermelha podem ser identificados pelo método IPC, padrões circulados na cor amarela foram identificados pelo 
(continuação da legenda Figura 45)

método HILIC, os padrões circulados em azul não foram identificados nos métodos cromatográficos.

As amostras foram coletadas durante a fase exponencial de crescimento, entre 20 e 40 horas de fermentação, nesta etapa a xilose é consumida ao passo que os metabólitos estão sendo produzidos.

Os três diferentes volumes de amostra, $1 \mathrm{~mL}, 2 \mathrm{~mL}$ e $5 \mathrm{~mL}$, foram analisados por UHPLC-MS. Os cromatogramas de íon totais destas amostras indicam que, quanto maior o volume de amostra, maior a intensidade do sinal detectado no equipamento (Figura 46). No entanto, o volume escolhido para a otimização do preparo de amostra foi $2 \mathrm{~mL}$, pois este foi o volume máximo que se adequou ao preparo de amostra com as menores perdas durante 0 processo.

a)

b)

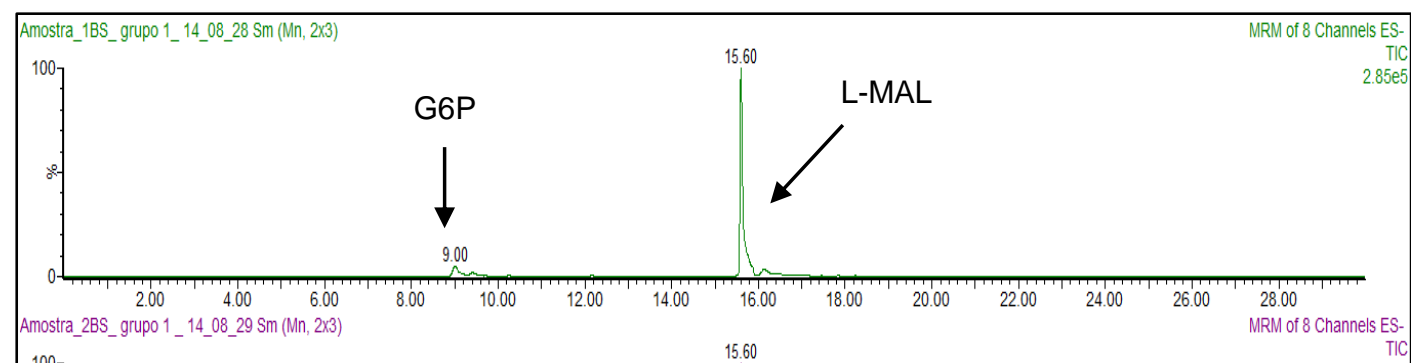

c)

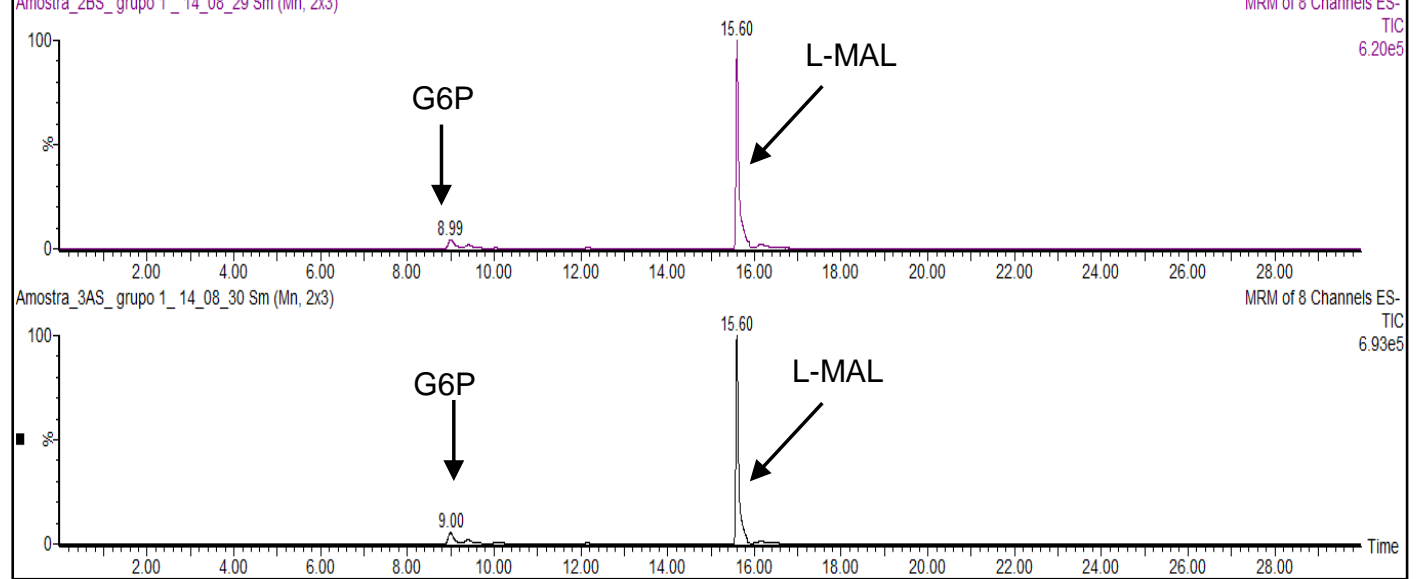

Figura 46. Cromatogramas dos canais MRM dos metabólitos produzidos pela levedura S. passalidarum analisados pelo método IPC. (a) Volume de amostra $1 \mathrm{~mL}$ (b) Volume de amostra $2 \mathrm{~mL}$ (c) Volume de amostra $5 \mathrm{~mL}$. 
O diluente escolhido para a reconstituição dos extratos biológicos foi água ultra pura (Mili-Q), tendo em vista que os padrões de metabólitos utilizados no desenvolvimento do método cromatográfico otimizado foram diluídos em água. O volume escolhido para este procedimento foi $200 \mu \mathrm{L}$, este volume garante que pelo menos $175 \mu \mathrm{L}$ de sobrenadante possam ser obtidos após o processo de centrifugação. Desta forma, este foi menor o volume de reconstituição, a fim de obter a amostra mais concentrada possível.

A análise de amostras reais mostrou ser mais complexa devido ao efeito de matriz. A matriz biológica contém diversas espécies que podem provocar uma resposta instrumental que interfira na deteç̧ão do analito. Os cromatogramas das amostras reais dos protocolos analíticos otimizados (Figuras 47 a 50) indicam que a co-eluição de compostos presentes na matriz altera significativamente a ionização do analito de interesse e consequentemente o perfil do cromatograma.

a)

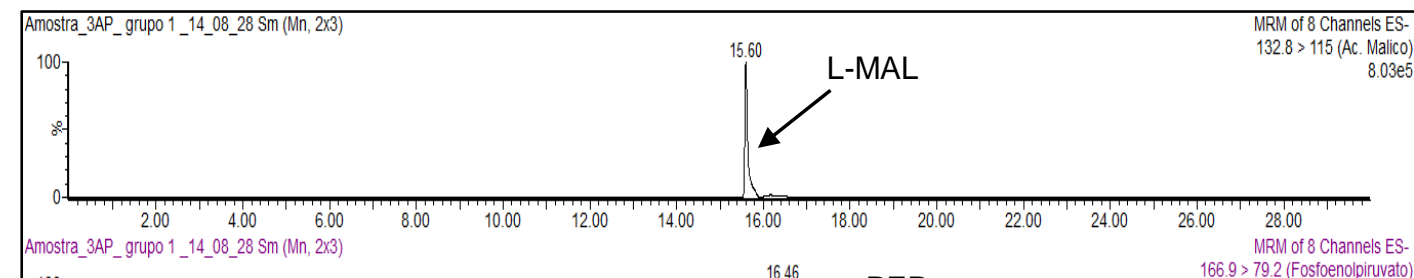

b)

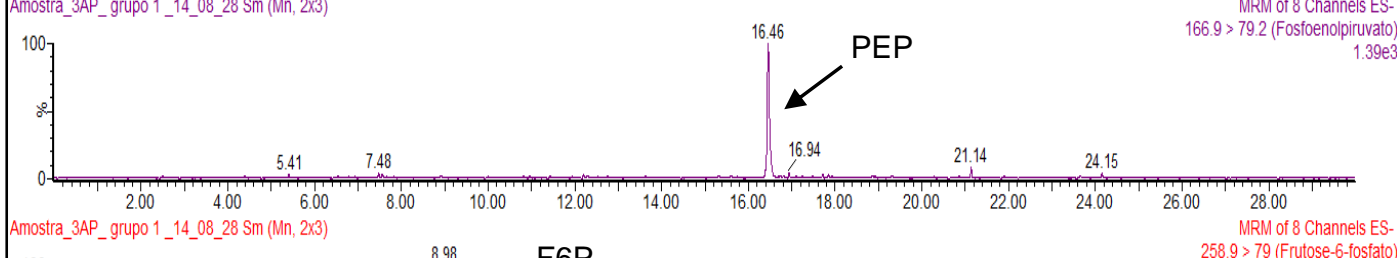

c)

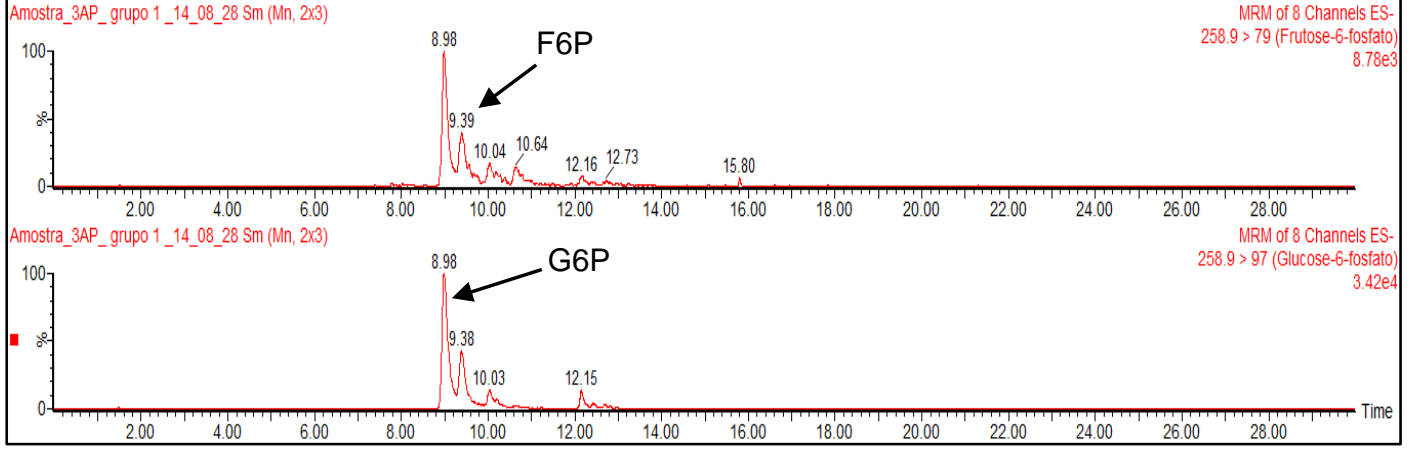

Figura 47. Cromatogramas dos canais MRM dos metabólitos produzidos pela levedura S. stipitis analisados pelo método IPC. Metabólitos intracelulares identificados: a) ácido málico, b) fosfo(enol)piruvato, c) frutose-6-fosfato e d) glicose-6-fosfato. 


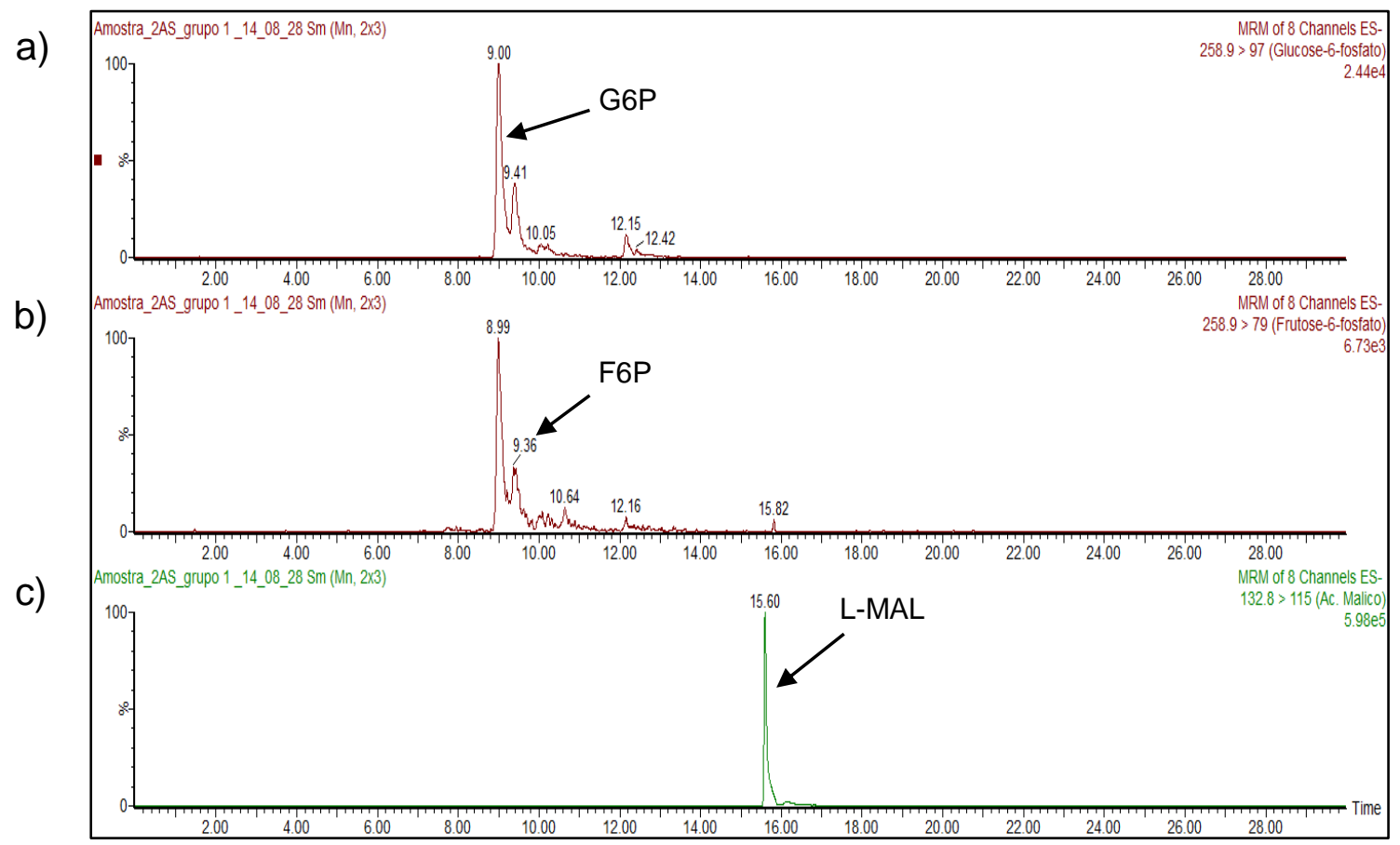

Figura 48. Cromatogramas dos canais MRM dos metabólitos produzidos pela levedura $S$. passalidarum analisados pelo método IPC. Metabólitos intracelulares identificados: a) glicose-6-fosfato, b) frutose-6-fosfato e c) ácido málico. 


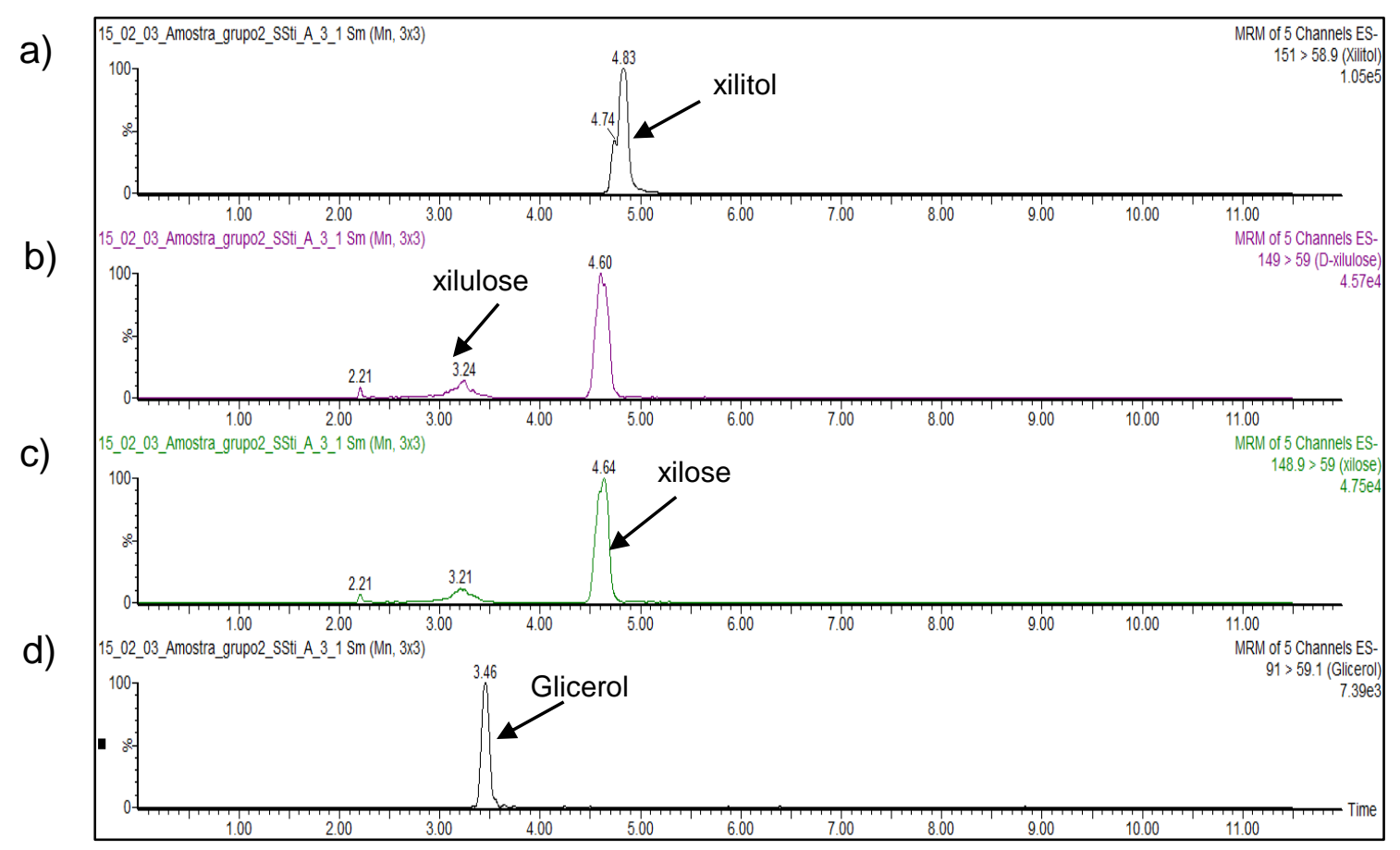

Figura 49. Cromatogramas dos canais MRM dos metabólitos produzidos pela levedura S. stipitis analisados pelo método HILIC. Metabólitos identificados: a) xilitol, b) xilulose, c) xilose e d) glicerol.

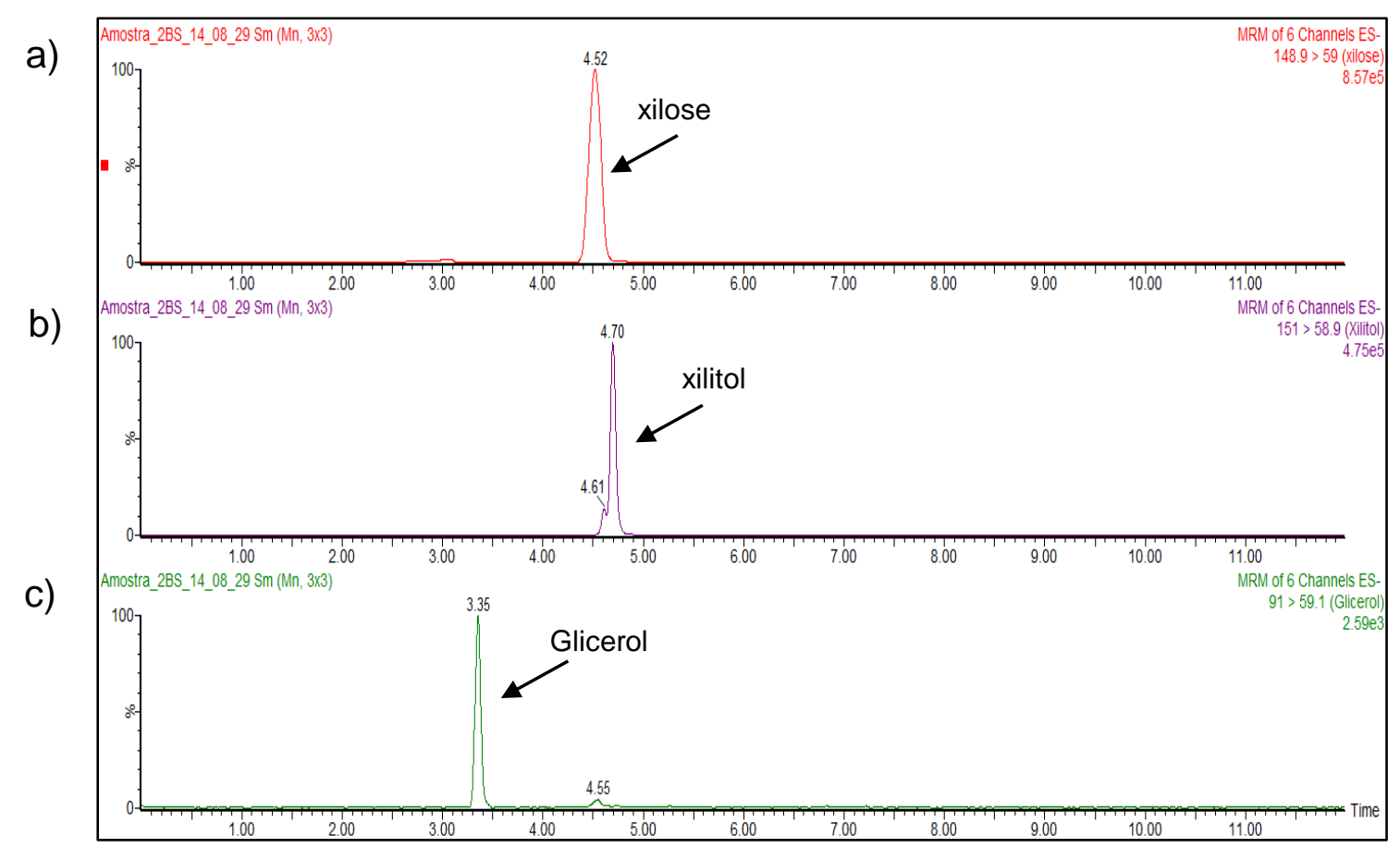

Figura 50. Cromatogramas dos canais MRM dos metabólitos produzidos pela levedura $S$. spathaspora analisados pelo método HILIC. Metabólitos identificados: a) xilose, b) xilitol e c) glicerol. 
Os métodos desenvolvidos neste trabalho são capazes de identificar metabólitos da via fermentativa em amostras de leveduras. Apesar de catorze padrões de metabólitos terem sido identificados pelos métodos por UHPLCMS/MS, os cromatogramas apresentados indicam que para as duas leveduras analisadas, um total de oito metabólitos foram identificados sendo estes: ácido málico, frutose-6-fosfato, glicose-6-fosfato, fosfo(enol)piruvato, glicerol, xilitol, xilulose e xilose (Figura 51). Alguns fatores podem ter contribuído para justificar os resultados encontrados: i) as leveduras testadas produziram apenas os metabólitos detectados nas condições de fermentação utilizada; ii) a concentração dos metabólitos produzidos pelas leveduras encontram-se abaixo do limite de detecção do método e iii) alguns metabólitos sofrem degradação na etapa de preparo de amostra e por isso não foram detectados. 


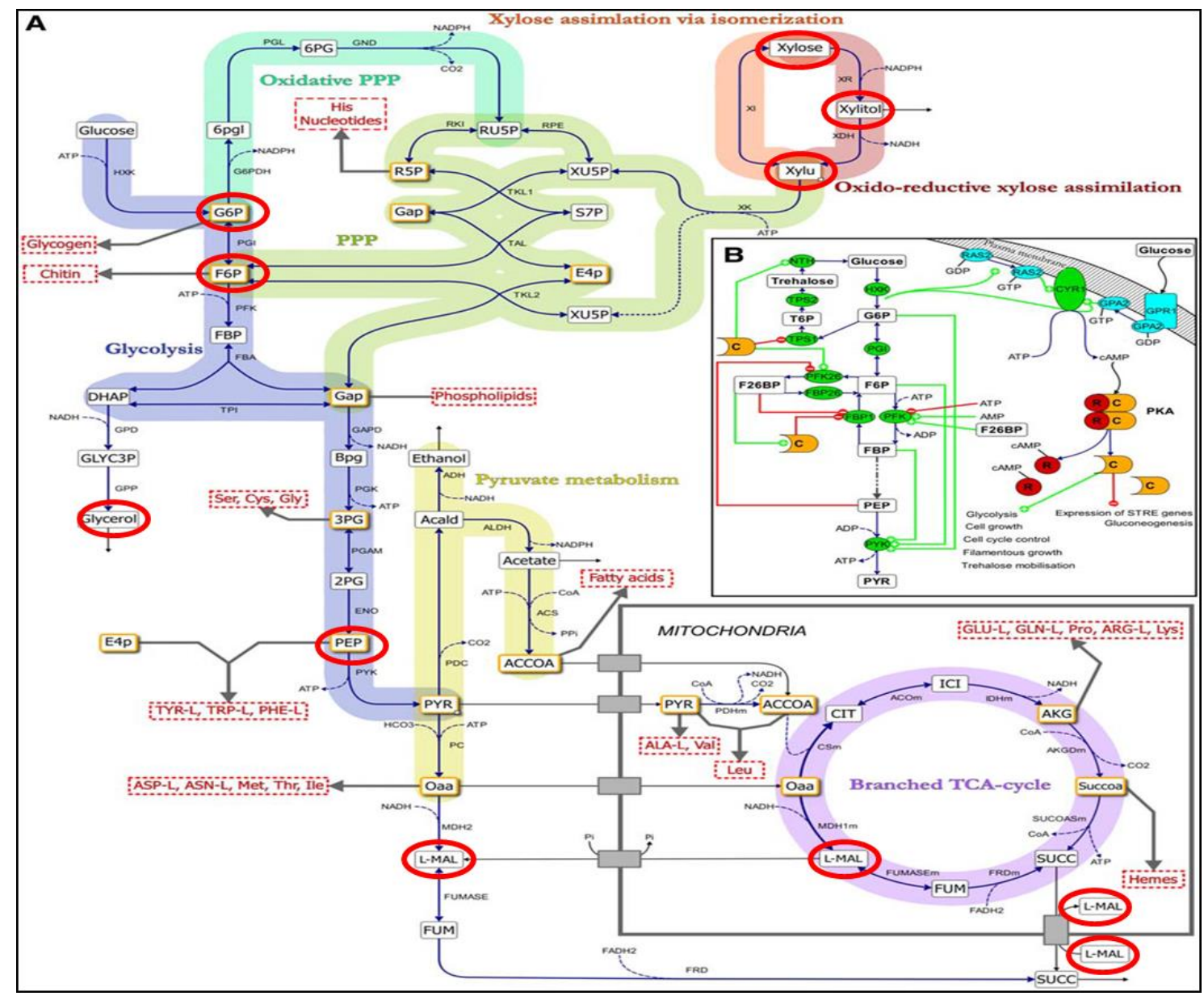

Figura 51. Visão geral das principais reações metabólicas no metabolismo do carbono central. Compostos circulados em vermelho foram detectados nas amostras de duas leveduras analisadas S. stipitis e S. spathaspora. 
CONCLUSÃO 


\section{CONCLUSÃO}

O estudo baseado em metabolômica é sem dúvida desafiador e fornece diferentes caminhos para o desenvolvimento de uma estratégia eficiente, viável, e que possa contribuir com a investigação do metabolismo de leveduras fermentadoras de xilose. Neste trabalho, protocolos analíticos foram desenvolvidos e otimizados para análises metabolômicas de leveduras, desde o processo de preparo da amostra até a análise dos metabólitos.

Para o preparo da amostra, foram otimizados os métodos de quenching e de extração de metabólitos para leveduras fermentadoras de xilose. Para as análises dos metabólitos extraídos, utilizou-se a técnica de UHPLC-MS, com a abordagem MRM (Multiple Reaction Monitoring), a qual possui alta sensibilidade e seletividade, uma vez que alguns metabólitos de interesse estão presentes em poucas quantidades e/ou são isômeros. Devido à diferença das classes dos metabólitos presentes na via de fermentação da xilose, não foi possível desenvolver um método analítico capaz de detectar e identificar todos os metabólitos de interesse. Portanto, dois métodos analíticos foram desenvolvidos e otimizados, um baseado em Cromatografia de Pareamento lônico (IPC) e outro em Cromatografia de Interação Hidrofílica (HILIC), para a quantificação de 14 metabólitos presentes na via fermentativa para a produção de etanol. A partir do método IPC foi possível separar nove metabólitos (G6P, F6P, GAP, PEP, R5P, DHAP, L-MAL, PYR e AKG) e a partir do método HILIC foi possível separar cinco metabólitos (glicose, xilose, xilulose, glicerol e xilitol).

Os protocolos analíticos desenvolvidos foram testados utilizando duas leveduras fermentadoras de xilose, Scheffersomyces stipitis e Spathaspora passalidarum. No total, oito metabólitos foram identificados nas amostras das leveduras demonstrando que os protocolos desenvolvidos foram capazes de extrair e detectar os metabólitos produzidos. No entanto, ainda será necessário: i) otimizar os processos de fermentação para as duas leveduras testadas, ii) determinar o limite de detecção dos métodos e iii) realizar estudos de recuperação e estabilidade para estimar possíveis perdas e degradações durante as etapas de preparo e armazenamento das amostras. 
Os métodos analíticos desenvolvidos deverão ser validados para quantificação dos metabólitos em trabalhos futuros.

O trabalho desenvolvido foi eficiente e viável para elucidar o estudo metabolômico de leveduras fermentadoras de xilose e podem ser utilizados para analisar os catorze metabólitos detectados, independente da matriz biológica. 


\section{REFERÊNCIAS \\ BIBLIOGRÁFICAS}




\section{REFERÊNCIAS BIBLIOGRÁFICAS}

1. Solomon, D. B.; Ann. N. Y. Acad. Sci. 2010, 1185, 119.

2. Singh, A.; Pant, D.; Korres, E. N.; Nizami, A.; Prasad, S.; Murphy, D.J.; Bioresour. Technol. 2010, 101, 5003.

3. Cook, C.; Devoto, A.; J. Sci. Food Agric. 2011, 91, 1729.

4. Hahn-Hägerdal, B.; Galbe, M.; Gorwa-Grauslund, M. F.; Lidén G.; Zacchi, G.; Trends in Biotechnol. 2006, 24, 549.

5. Gnansounou, E.; Dauriat, A.; Bioresour. Technol. 2010, 101, 4980.

6. Wasylenko, T.; Stephanopoulos, G.; Biotechnol. Bioeng., DOI 10.1002/bit.25447.

7. Balat, M.; Balat, H.; Öz C.; Progress in Energy and Combustion Science, 2008, 34, 551.

8. Dias, O. S. M.; Ensinas, A.; Nebra, S. A.; Filho, M. R.; Rossell, C. E. V.; Maciel, M. R. W.; Chemical Engineering Reserch and Design, 2009, 87, 1206.

9. Cardona, C. A.; Quintero, J. A.; Paz, I. C.; Bioresour. Technol. 2010, 101, 4754.

10. Dias, O. S. M.; Junqueira, L. T.; Cavalett, O.; Cunha, P.M.; Jesus, D. F. C.; Rossell, E. V. C.; Filho, M. R.; Bonomi A.; Bioresour. Technol. 2012, 103, 152.

11. Matsushika, A.; Goshima, T.; Hoshino, T.; Microbiol. Cell Factor. 2014, 13,16 .

12. Shi, J.; Zhang, M.; Zhang, L.; Wang, P.; Jiang, L.; Deng, H.; Microbial biotechnol. 2013, 7, 90.

13. Demeke, M. M.; Dumortier, F.; Li, Y.; Broeckx, T.; Moreno, R. M.; Thevelein, M. J.; Biotechnol. Biofuels, 2013, 6, 120.

14. Hollinshead, W.; He, L.; Tang, J. Y.; Frontiers in Microbiol. 2014, 5, 1.

15. Patti G.; Yanes, O.; Siuzdak, G., Molecular Cell Biology. 2012, 13, 263.

16. Zhou, B.; Xiao, J.; Tuli, L.; Ressom, H., Mol. Bio. Syst. 2012, 8, 470.

17. Dunn, W.; Ellis, D.; Trends in Analytical Chemistry, 2005, 24, 4.

18. Rochfort, S.; J. Nat. Prod. 2005, 68, 1813.

19. Krastanov A.; Biotechnol. Biotechnol. 2010, 24, 1537.

20. Sumner, W. L.; Mendes, P.; Dixon, A. R.; Phytochemistry, 2003, 62, 817.

21. Abdelnur, P. V.; Caldana, C.; Martins, C.M.; Chem. Biol. Technol. Agri. 2014, 22, 1.

22. Brown, M.; Dunn, W. B.; Dobson, P.; Patel, Y.; Winder, C. L.; FrancisMclntyre, S; Begley, P.; Carrol, K.; Analyst, 2009, 134, 1322.

23. Mashego, M. R.; Rumbold, K.; De Mey, M.; Vandamme, E.; Soetaert, W.; Heijnen, J. J.; Biotechnol. Lett. 2007, 29, 1.

24. Park, C.; Lee, Y.; Lee, S. Y.; Oh, H. B.; Lee, J.; Bull. Korean Chem. Soc. 2011, 32, 524.

25. Canelas, A. B.; Ras, C.; Pierick, ten A.; van Dam, J. C.; Heijnen, J. J.; van Gulik, W. M.; Metabolomics, 2008, 4, 226.

26. Kim, S.; Lee, D. Y.; Wohlgemuth, G.; Park, H. S.; Fiehn, O.; Kim, K. H.; Anal. Chem. 2013, 85, 2169. 
27. Neubauer, S.; Haberhauer-Troyer, C.; Klavins, K.; Russmayer, H.; Steiger, M. G.; Gasser, B.; Sauer, M.; Mattanovich, D.; Hann, S.; Koellensperger, G.; J. Sep. Sci. 2012, 35, 3091.

28. Villas-Bôas, S. G.; Hojer-Pedersen, J.; Akesson, M.; Smedsgaard, J.; Nielsen, J.; Yeast, 2005, 22, 1155.

29. De Koning, W.; van Dam, K.; Anal. Biochem. 1992, 204, 118.

30. Park, C.; Yun, S.; Lee, S. Y.; Park, K.; Lee, J.; Appl. Biochem. Biotechnol. 2012, 167, 425.

31. Carnicer, M.; Canelas, A. B.; Pierick, ten A.; Zeng, Z.; van Dam, J. C.;Albiol, J.; Ferrer, P.; Heijnen, J. J.; van Gulik, W.; Metabolomics, 2012, 8, 284.

32. Canelas, A. B.; ten Pierick, A.; Ras, C.; Seifar, M. R.; van Dam, J. C.; van Gulik, W. M.; Heijnen, J. J.; Anal. Chem. 2009, 81,7379.

33. Skoog, D.A; West, D.M; Holler, F.J. \& Stanley, R.C.; Fundamentos de Química Analítica, $8^{\text {st }}$ ed.; Tradução Norte Americana; 2001.

34. Lei, Z.; Huhman, D. V.; Sumner, W. L.; J. Biol. Chem. 2011, 286, 25435.

35. Chiaradia, M. C.; Collins, C. H.; Jardim, I.; Quim. Nova, 2008, 31, 623.

36. Hoffmann, E.; Stroobant, V.; Mass Spectrometry: Principles and Applications, $3^{\text {st }}$ ed, Wiley, 2007.

37. Forcisi, S.; Moritz, F.; Kanawati, B.; Tziotis, D.; Lehmann, R.; SchimittKopplin, P.; J. Chromatogr. A, 2013, 1292, 51.

38. Moraes, M. C.; Lago, C. L.; Quim. Nova, 2003, 26,556.

39. Hojer-Pedersen, J.; Smedsgaard, J.; Nielsen, J.; Metabolomics, 2008, 4, 393.

40. Lu, W.; Bennett, B. D.; Rabinowitz, J. D.; J.Chromatogr. B, 2008, 871, 236.

41. Tomita, M.; Nishioka, T.; Metabolomics The Frontier of Systems Biology, $1^{\text {st }}$ ed, Tokio, JPN, 2005.

42. Bedair, M.; Sumner, L. W.; Trends in Anal. Chem. 2008, 27, 238.

43. Monton, M. R.; Soga, T.; J.Chromatogr.A, 2007,1168, 237.

44. Simionato, A. V.; Assunção, N. A.; Bechara, E. J.; Tavares, M. F.; Carrilho, E.; Quim. Nova, 2008, 31, 2124.

45. Büscher, J. M.; Czernik, D.; Ewald, J. C.; Sauer, U.; Zamboni, N.; Anal. Chem. 2009, 81, 2135

46. Guillarme, D.; Schappler, Rudaz, S.; Veuthey; Trends in Anal. Chem. 2010, 29, 15.

47. Bajad, S. U.; Lu, W.; Kimball, E. H.; Yuan, J.; Peterson, C.; Rabinowitz, J. D.; J.Chromatogr.A, 2006, 1125, 76.

48. Tang, D.; Zou, L.; Yin, X.; Ong, C. N.; DOI: 10.1002/mas.21445.

49. Alpert, A. J.; J.Chromatogr. 1990, 499, 177.

50. Stählberg, J.; J.Chromatogr.A, 1999, 855, 3.

51. Acikara, B. Ö; DOI: $10.5772 / 55744$

52. Wohlbach, D.; Kuo, A.; Sato, T. K.; Potts, K. M.; PNAS 2011, 108, 13212.

53. Basso, L. C, de Amorim H.V, de Oliveira A .J., Lopes, M. L.; FEMS Yeast Res. 2008, 5, 399.

54. Almeida, J. R.; Runquist, D.; Sanchez N. V.; Liden, G.; Gorwa-Grauslund, M. F.; Biotechol. J. 2011, 6, 286.

55. Karhumaa, K.; Hahn-Hägerdal, B.; Gorwa-Grauslund, M. F.; Yeast, 2005, 22, 359. 
56. Kuyper, M.; Hartog, M. M.; Toirkens, M.J., Almering, M.J.; Winkler, A.A.; van Dijken, J. P.,Pronk, J.T.; FEMS Yeast Res. 2005, 5, 1155.

57. Runquist, D.; Hahn-Hägerdal, B.; Bettiga, M.; Appl. Environ. Microbiol. 2010a, 76, 7796.

58. Runquist, D.; Hahn-Hägerdal, B.; Radström, P.; Biotechnol.Biofuels, 2010b, $3,5$.

59. Parachin; Skorupa, N.; Basti, B.; van Niel, W. J.; Gorwa-Grauslund, M. F.; Metabolic Engeneer. 2011, 13, 508.

60. Nielsen, J. ; Jewett, M. C.; FEMS Yeast Res. 2008, 8, 122.

61. Bergdahl, B.; Heer, D.; Sauer, U.; Hahn-Hägerdal, B.; van Niel, W.J.; Biotechnol. Biofuel, 2012, 5, 34.

62. Hasunuma, T; Sanda, T.; Yamada, R.; Yoshimura, K.; Ishil, J.; Kondo, A.; Microbial cell Factories, 2011,10, 2.

63. Buescher, J. M.; Moco, S.; Sauer, U.; Zamboni, N.; Anal. Chem. 2010, 82, 4403.

64. Luo, B.; Groenke, K., Takors, R.; Wandrey, C.; Oldiges, M.; J.Chromatogr.A, 2007, 1147, 153.

65. Scarlata, J. C.; Hyman, D. A.; J.Chromatogr.A, 2010, 1217, 2082.

66. Li, Y.; Ptolemy, A. S.; Harmonay, L.; Kellog, M.; Berry, G. T.; Mol. Genet. Metabol. 2011, 102, 33. 